\title{
Detailed Petrographic Descriptions and Microprobe Data for Tertiany Silicic Volcanic Rocks in Drill Hole USW G-1, Yucca Mountain, Nevada
}

\author{
F. A. Caporuscio \\ R. G. Warten \\ D. E. Broxton
}

\section{DISCLAIMER}

\begin{abstract}
This report was prepared as an account of work sponsored by an agency of the United States Government. Neither the United States Government nor any agency thereof, nor any of their employees, makes any warranty, express or implied, or assumes any legal liability or responsibility for the accuracy, completeness, or usefulness of any information, apparatus, profuct, or process disclosed, or represents that its use would not infringe privately owned rights. Reference herein to any specifie commercial product, process, or service by trade name, trademark, manufacturer, or otberwise does not necessarily consticule or irtuply its endorsement, recommendation, of favoring by the United States Government or any agency thereof. The views and opinions of authors expressed herein do not necessarily state or reflect thase of the United States Gevernuent or any agency thereof.
\end{abstract}

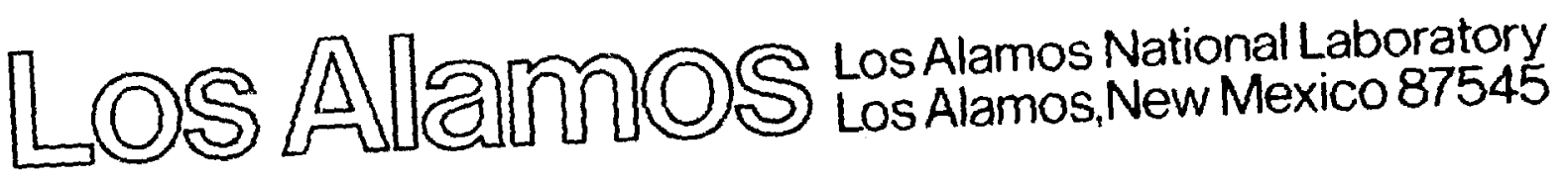


DETAILED PETROGRAPHIC DESCRIPTIONS AND MICROPROBE DATA FOR TERTIARY SILICIC VOLCANIC ROCKS IN DRILL HOLE USW G-1, YUCCA MOUNTAIN, NEVADA

by

F. A. Caporuscio, R. G. Warren, and D. E. Broxton

\section{ABSTRACT}

This report contains detailed petrographic descriptions of 74 thin sections from drill hole USW G-1 at Yucca Mountain, Nevada. These descriptions are keyed to the distinctions between devitrified, vitrophyre, vitric, and zeolitized intervals below the Topopah Spring Member repository horizon. The petrographic features of the zeolitized intervals down through the Crater Flat tuff, as well as the sorption properties determined from these intervals, suggest that these zeolite occurrences may each have comparable sorptive capability.

\section{INTRODUCTION}

This report supplements the data in "Preliminary Stratigraphic and Petrologic Characterization of Core Samples from USW G-1, Yucca Mountain, Nevada" by Bish et a1. (1981) and in "Further Description of the Petrology of the Topopah Spring Member of the Paintbrush Tuff in Drill Holes UE-25a-1 and USW-G1 and the Lithic-kich Tuff in USW-G1, Yucca Mountain, Nevada" by Carroll et al. (1981). It provides detailed petrographic descriptions and microprobe data from which the summaries of the earlier two reports were prepared. These reports are part of a series of studies in the Nevada Nuclear Waste Storage Investigations (NNWSI), managed by the US Department of Energy's Nevada Operations office, to determine the suitability of Tertiary ash-flow tuffs underlying Yucca Mountain for an underground high-level nuclear waste repository. Yucca Mountain, located in the southeast portion of the Nevada Test Site (NTS) in south-central Nevada, is one of several sites in the country being considered for such a repository. A major requirement in 
evaluating the suitability of the Yucca Mountain site is determination of the mineralogy and petrology along transport pathways, both through the host rock and toward the accessible environment. Although tuff is a complex rock type with highly variable mineralogy, it is relatively easy to subdivide the Yucca Mountain tuffs into the four petrologic categories of devitrified, vitrophyre, vitric, and zeolitized. The purpose of this report is to summarize the variation within and among those petrologic categories and to evaluate their relative importance along transport pathways, based on the samples from USW G-1.

Relatively few of the original primary glasses in the ash flows underlying Yucca Mountain have survived postemplacement alteration processes such as devitrification, vapor phase alteration, and zeolitization. Therefore, secondary minerals greatly influence the bulk physical and chemical properties of these rocks. Los Alamos studies have concentrated on characterizing the distribution, mineralogy, and composition of these secondary minerals. Particular emphasis has been placed on zeolites and clays, because they are highly sorptive and provide important natural barriers to radionuclide migration.

USW G-1 is an exploratory drill hole located in central Yucca Mountain at the north end of the area currently being considered for a repository (Fig. 1). It was drilled and continuously cored to a depth of 6000 feet (1829 m) to investigate the stratigraphy and structure of Yucca Mountain. It also was drilled to compare the lateral continuity, competency, and mineralogy of penetrated tuffs with tuffs in other exploratory drill holes planned or completed in the Yucca Mountain area. Representative samples were collected for major lithologic subdivisions using drill core logs prepared by the United States Geological Survey (USGS). Transmitted and reflected light microscopy techniques were used to identify the major mineral phases present and to determine their mode of occurrence. Paragenetic relations of secondary minerals were noted wherever possible. An explanation of the terminology used to describe welding textures in thin sections is given in Table 1.

This report contains detailed petrographic descriptions of thin sections prepared from the USW G-1 drill core. Each is numbered according to depth in the drill core (in feet) and is listed in the text according to sequence downward within a formal stratigraphic interval le.g., Tpt-1, Tpt-2, Tpt-3 within the Topopah Spring Member of the Paintbrush tuff - Tpt). However, the 


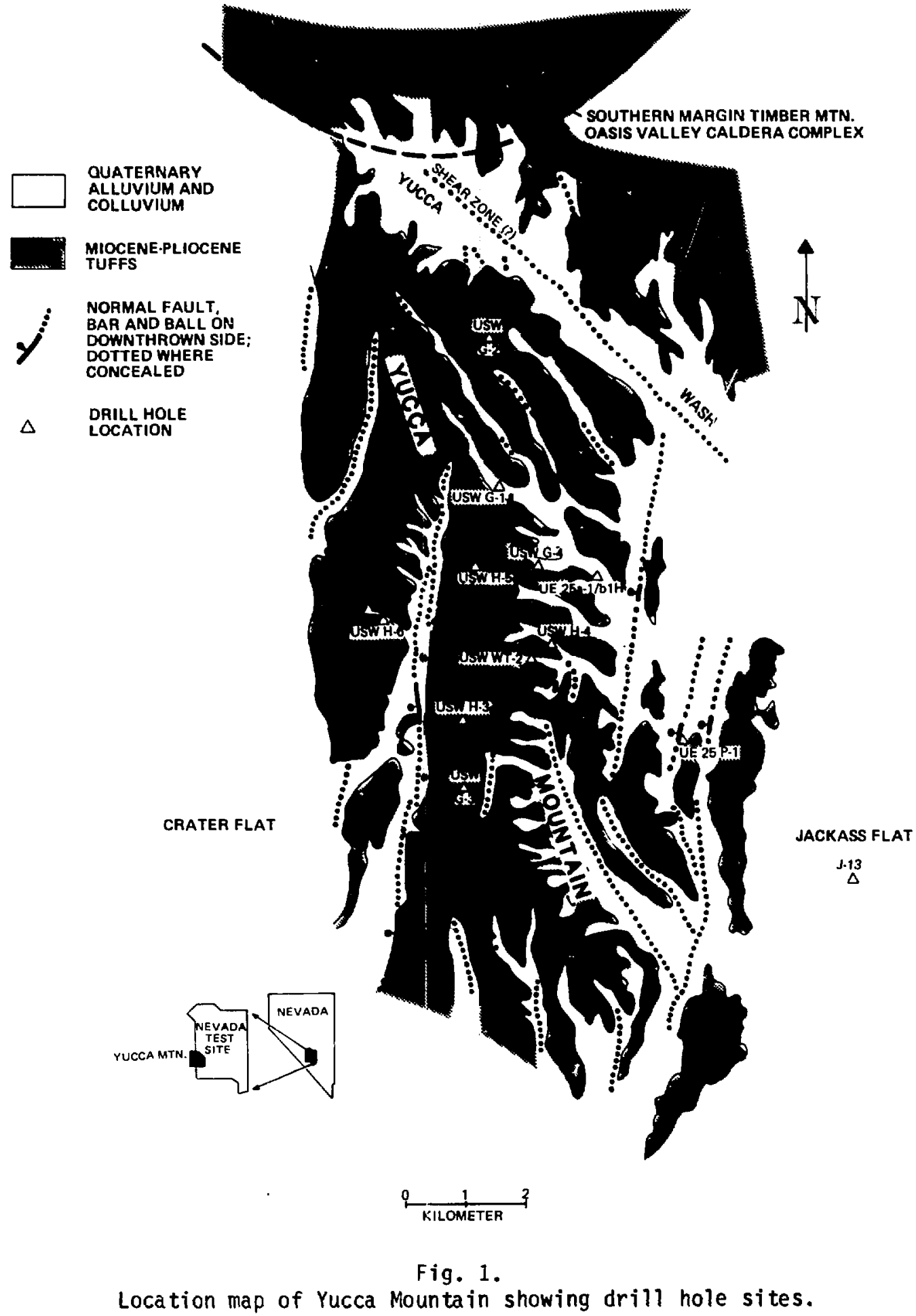




\section{TABLE I}

EXPLANATION OF TERMINOLOGY CONCERNING DEGREE OF WELDING IN THIN SECTION

Nonwelded

Slightly welded

Partily welded

Modera tely welded

Densely welded

vitrophyric
-- No deformation of components.

-- Minor shard defornation around phenocrysts.

-- Major shard deformation around phenocrysts; no flow deformation in groundmass.

-- Major shard deformation around phenocrysts; deformation and flow in groundmass.

-- Pronounced shard deformation and alignment.

-- Glassy, all vitric components annealed (perlitic fractures may occur).

major subdivisions of the text are based on petrologic type rather than on formal stratigraphic units. These petrologic subdivisions are numbered in the text as:

(II) The lower repository horizon within the Topopah Spring Member. This rock type consists of densely welded phenocryst-poor tuff devitrified to quartz, cristobalite, and alkali feldspar.

(III) Zeolite Interval I. The first occurrence of potentially sorptive zeolites (clinoptilolite) immediately below the repository horizon. This interval occurs on top of the basal vitrophyre of the Topopah Spring Member.

(IV) The basal vitrophyre of the Topopah Spring Member. This interval consists of dense glassy tuff with minor alkali feldspars and silica minerals, and trace amounts of silicate and oxide phenocrysts. Clays and zeolites are rare in this interval.

(V) Vitric zone, Topopah Spring Member. This is an interval of slightly to partly welded glassy tuff, less dense than the overlying vitrophyre and with traces of clinoptilolite alteration.

(VI) Zeolite Interval II. In USW G-1, this is a zone of abundant clinoptilolite zeolitization which coincides with the Tuff of Calico Hills and the upper Prow Pass Member of the Crater Flat Tuff. 
(VII) The Central Prow Pass Member, Crater Flat Tuff. This is a zone of partly to moderately welded tuff devitrified to quartz, cristobalite and alkali feldspar.

(VIII) Zeolite Interval III. In USW G-1, this is a zone of abundant clinoptilolite and mordenite zeolitization which encompasses the lower Prow Pass Member and upper Bullfrog Member of the Crater Flat Tuff.

(IX) The Central Bullfrog Member, Crater Flat Tuff. This is a zone of partly to moderately welded tuff devitrified to quartz, cristobalite and alkali feldspar. Although generally similar in major mineralogy to the central Prow Pass Member, there is more clay alteration of the devitrified Bullfrog Member.

(x) Zeolite Interval IV. In USW G-1, this is a zone of abundant clinoptilolite and mordenite zeolitization encompassing the lower Bullfrog Member and upper Tram Member of the Crater Flat Tuff.

(XI) Deeper petrologic zones include the underlying devitrified Tram Member, the zeolitized and clay-rich base of the Tram Member, a dacite flow breccia altered to clay and zeolites, and the underlying Tuff of Lithic Ridge and older ash-flow units. Mordenite is absent at this depth, but clinoptilolite occurs within the lower Tram Member and in the underlying dacite lava. These clinoptilolite occurrences are included within zeolite Interval $V$, which is poorly constrained stratigraphically. The sorptive zeolites clinoptilolite and mordenite do not occur below the dacite flow breccia, and for extrapolation of petrologic properties across Yucca Mountain (Bish et al. 1984), these complex deeper petrologic zones (including Zeolite Interval $v$ ) are not subdivided.

These petrologic subdivisions are centered around the occurrences of major intervals of sorptive zeolites. Further discussion of these zeolite intervals can be found in Vaniman et al. (1984), and all of the petrologic intervals are described in their regional context by Bish et al. (1984).

Ubiquitous Fe-Ti oxides are observed as microphenocrysts and as alteration products in the ash flows and lavas. Morphologies indicate that both cubic [magnetite-ülvospinel solid solution series (Mt-Usp $\mathrm{ss}_{\mathrm{s}}$ )] and rhombohedral [ilmenite-hematite solid solution series (IIm-Hem $\left.\left.{ }_{\text {ss }}\right)\right]$ phases are present. Subsequent oxidation of the Fe-Ti oxides after eruption produced a series of oxidation exsolution phases in the original grains. Haggerty (1976) devised a 
series of empirical oxidation exsolution stages for Doth the cubic $\left(C_{1}\right.$ to $\left.C_{7}\right)$ and rhombohedral $\left(R_{1}\right.$ to $\left.R_{7}\right)$ phases, where 1 denotes unoxidized and 7 denotes complete oxidation. That classification is used in this report to identify the relative maximum oxidation state of the samples (Table II). In all cases, the oxidation state of the Ilm-Hemss closely parallels that of the Mt-Üsp ${ }_{s s}$. Therefore, all oxides reported are given a $c_{x}$ notation for consistency. The oxidation state of the $\mathrm{Fe}-\mathrm{Ti}$ oxides is dependent on the highest ambient $\mathrm{fO}_{2}$, which may often be correlated to the permeability and degree of welding of the tuffs. In nonwelded tuffs (high permeability), the Fe-Ti oxides are generally oxidized $\left(c_{5}-c_{7}\right)$. Densely welded tuffs (low permeability) tend to record low oxidation states $\left(c_{1}-c_{3}\right)$. Due to the kinetics of oxidation exsolution, the retrograde process is extremely sluggish. Therefore, the oxidation state recorded is the highest level obtained and not always indicative of the present oxygen fugacity in the tuffs.

Mineral compositions were determined on an automated Cameca electron microprobe with accelerating potential fixed at $15 \mathrm{kV}$ and sample current at $0.015 \mu \mathrm{A}$ on thorium oxide. Analyses were made at either $10 \mathrm{~s}$ or 30000 counts

TABLE II

EXSOLUTION OXIDATION OF Fe-Ti OXIDE CUBIC AND RHOMBOHEDRAL PHASES ${ }^{a}$

$\underline{\text { Cubic }}$

$c_{1}$ magnetite

$c_{2}$ magnetite $(+i$ menite)

$c_{3}$ ilmenite + magnetite

$c_{4}$ mottled ilmenite + magnetite +

rutile + hematite + pleonaste

(meta-ilmenite)

$c_{5}$ rutile + titanohematite

$c_{6}$ rutile + titanohematite

(+ pseudobrookite)

C) pseudobrookite + (titano-

hema tite + rutile)
Rhombohedral

$$
\begin{array}{ll}
R_{1} & \text { ilmenite } \\
R_{2} & \text { ilmenite + rutile } \\
R_{3} & \text { rutile + ilmenite } \\
R_{4} & \text { rutile + titanohematite + } \\
& \text { ferrian rutile + ferrian } \\
& \text { ilmenite } \\
R_{5} & \text { rutile + titanohematite } \\
R_{6} & \text { rutile + titanohematite } \\
& \text { (+ pseudobrookite) } \\
R_{7} \text { pseudobrookite + (rutile + } \\
\text { titanohematite) }
\end{array}
$$

a After Haggerty, 1976. 
for each element. Compositions were calculated from corrected peak intensities using the methods of Bence and Albee (1968). Chemical data for zeolites, secondary feldspars, and clays are listed in the Appendix.

In this report phenocryst and accessory minerals are listed in order of abundance. The point counts for volume percent phenocrysts, lithics, and voids used in this report were taken from Warren et al. (1984). The point count of void volumes represents only those voids having diameters in excess of $30 \mathrm{\mu m}$, i.e., voids large enough to recognize microscopically for the point count. The actual porosity of the rock is always greater because numerous sub-microscopic spaces cannot be point counted. The reader is referred to Warren et al. (1984) for more detailed information on the modal petrography and phenocryst chemistry of USW G-1 cores.

I1. LOWER REPOSITORY HORIZON, TOPOPAH SPRING MEMBER

(Tpt) Topopah Spring Member, Paintbrush Tuff

Tpt-1. G1-1191 Densely welded, devitrified, ash-flow tuff

Shards - similar to Gl-1240 (following). Some 100-um-diameter spheres are present in most shards. These spheres have very low refractive index (possibly chalcedony after opal). Second-order yellow phase (clay?) is present.

Pumice - similar to G1-1240 - also small-scale (100- $\mu \mathrm{m})$ spherulites are present in most pumice. Possible opal to chalcedony fillings occur in some innermost regions of pumice.

Fracture - alteration up to $2 \mathrm{~mm}$ on each side of fracture. One region shows gradation from coarse quartz and $\mathrm{K}$-feldspar (400 $\mu \mathrm{m}$ long) to abundant spherulites $(200 \mu \mathrm{m})$ to an unaltered region.

In another portion, alteration occurs along a fracture-cutting pumice. Closest to the vein are second-order yellow sheaf crystals (terminated, blocky) $125 \mu \mathrm{m}$ long and $50 \mu \mathrm{m}$ wide in matrix of quartz, alkali feldspar, and oxides. Farther away are predominant ovoids of very low birefringent material $100 \mu \mathrm{m}$ in diameter [possible zeolite or opal (?)] in a matrix of quartz, alkali feldspar, and oxides (all fine grained). Beyond this is unaltered material. In color, the alteration zone around the fracture is bleached relative to the wall rock. 
Phenocrysts (1.8\%) - plagioclase, sanidine, quartz, and biotite.

Accessory minerals - allanite, zircon, apatite.

oxide $-c_{1}$ to $c_{7}$ depending on how close to fracture (i.e., $c_{1}$ far

from fracture, $c_{7}$ very close to fracturel. Possible late-stage zeolitization occurs in the centers of vugs.

Tpt-2. G1-1240 Densely welded, devitrified, ash-flow tuff

Matrix - severely deformed, 1- to 2- $\mu \mathrm{m}$ grains. Same color as G1-1286 (orange), and most probably consisting of fine-grained cristobalite and alkali feldspar along with clays and oxides.

Shards - 2 to $3 \mathrm{~mm}$ - clear to black and white. Original axiolitic texture obliterated by recrystallization of quartz and alkali feldspar. Crystals are intergrown and up to $40 \mathrm{~mm}$ long. Some remnant spherulites are preserved. Clays and oxides are concentrated in the central regions of shards.

Pumice - 1 to $3 \mathrm{~mm}$. Pumices commonly have border regions $(80 \mu \mathrm{m})$ of fibrous intergrown cristobalite and alkali feldspar growing toward the pumice centers. Pumices are mantled by clays; interiors are filled with coarse granophyric quartz and alkali feldspar. Interstitial clays are also present. Some regions have a cloudy brown appearance (concentrated clays) with common occurrence of 50- $\mathrm{mm}$ ovoids containing a clear phase (clinoptilolite?). Some pumice and shard regions show spherulites cutting all relict boundaries.

cracks and fractures - filled with quartz. There is no obvious alteration around fractures.

Voids - due to plucking during preparation of thin section.

Phenocrysts (2.6\%) - plagioclase, sanidine, quartz, biotite.

Accessory minerals - zircon and apatite.

Oxides - mantled oxides as low as $C_{1}$, oxides near fractures $C_{5}$ to $c_{7}$. Orange in color, due to rutile needles.

Lithics (3.2\%) - volcanic fragments now all devitrified to quartz and alkali feldspar. 
11. ZEOLITE INTERVAL I

Ipt-3. G1-1286 Densely welded tuff at top of basal vitrophyre (partly altered by high-temperature devitrification and partly altered to zeolites)

Shards - deep red-orange to brown and deformed, up to $1.5 \mathrm{~mm}$ long, and colored by disseminated submicron rutile and hematite. Spherulites of cristobalite and alkali feldspar transgress all shard boundaries. Spherulites are typically $2 \mathrm{~mm}$ in diameter, with smaller spherulites in interstitial regions.

Veins - filled with clinoptilolite, typically $200 \mu \mathrm{m}$ wide and massively crystalline. Veins have fractured the rock up to $1 \mathrm{~mm}$ on either side and altered the wall rock to fine-grained clinoptilolite, clay and disseminated oxides $\left(C_{6-7}\right)$.

Elongate (zebra-stripe) lens - up to $4 \mathrm{~mm}$. It looks as though spherulites grew in from boundary, filled the lens, then recrystallized to quartz and K-feldspar. Centers of some have second-order lemon-yellow continuous crystal growth (50 um wide). Black stripes consist of clays(?).

Pumice - pumices contain large spherulites, up to $3 \mathrm{~mm}$ in diameter and unaltered. Some pumices grade directly into elongate lenses.

Lithophysae - present in one corner as spheres up to $1 \mathrm{~mm}$ in diameter. Lithophysal voids are filled with coarse intergranular clinoptilolite. A vein also breaks through a zone of weakness along sphere boundaries .

Phenocrysts (1.7\%) - sanidine, plagioc?ase, quartz, biotite, and hornblende.

Accessory minerals - apatite and zircon.

Oxides - hematite with ilmenite and primary rutile; primary magnetite with ilmenite. Many oxide grains are unaltered because of low host-rock porosity. Groundmass fe oxides are altered to rutile and hematite.

Lithics (10\%) - two large spherulite fragments; the rest are altered to quartz and alkali feldspar.

Voids - from plucking during thin sectici preparation (no primary voids). 
Fractures - cracks are filled by quartz, with no obvious alteration adjacent to veins. Late-stage vugs are filled by zeolites.

Clays - smectites rim most shards.

IV. BASAL VITROPHYRE, TOPOPAH SPRING MEMBER

Tpt-4. G1-1292 Densely welded, unaltered, vitrophyric tuff

Shards - up to 1 to $2 \mathrm{~mm}$. Glass shards are strongly deformed, brown in color, and unaltered except at their borders (outer $2 \mu \mathrm{m}$ ).

Fractures - common but thin $(2$ to $5 \mathrm{~lm})$, and much more abundant in pumice. Fractures occur en echelon and are filled with clays.

Pumice - up to $6 \mathrm{~mm}$ long. Unaltered and flattened. Incipient devitrification of glass occurs as tiny discrete spherules. Oxides (Fe or Mn) partially line pumice borders in rare cases.

Perlitic cracks cover the whole thin section and cross cut all material. Phenocrysts (0.9\%) - plagioclase, sanidine, quartz (commonly embayed), and biotite.

Accessory minerals - allanite, apatite, and zircon.

Oxides $-C_{1}$ to $C_{2}$, up to $300 \mu m$ in diameter. Includes rutile.

Lithics (4.5\%) - predominantly devitrified ash-flow fragments, from $4-\mathrm{mm}$ diam to $40 \mathrm{~km}$ long (very rounded).

V. VITRIC ZONE, TOPOPAH SPRING MEMBER

Ipt-5. G1-1392 slightly to partly welded vitric tuff (unaltered)

Shards - large $(2 \mathrm{~mm})$ and undeformed. Shards vary in size from $50 \mathrm{\mu m}$ to $2 \mathrm{~mm}$. Shard boundaries are lined with yellow smectite. Ovoid spaces in shards (gas bubbles) are of three types:

1. unfilied,

2. filled totally by clays, and

3. rimmed by clay and then filled by small acicular clinoptilolite crystais.

Groundmass - large oxides (20 to $40 \mathrm{\mu m}$ ) occur throughout the groundmass. The groundmass is dark brown in color due to disseminated clays and oxides.

Pumice - up to $8 \mathrm{~mm}$ long, deep brown. Clays are abundant within pumices. Open voids are partly filled with fine clinoptilolite and then with late-stage growth of opal. The fine-grained matrix may be 
a combination of clays, oxides, clinoptilolite and/or glass. The pumices apparently altered first. Pumice has altered from glass to clays plus clinoptilolite with some opal. Pumices have varying degrees of alteration.

Phenocrysts (0.6\%) - plagioclase, sanidine, quartz, and biotite.

Accessory minerals - zircon and apatite.

Oxides - primarily rutile and hematite with ilmenite, $\mathrm{C}_{4}-\mathrm{C}_{5}$.

Lithics (1.2\%) - Two volcanic fragments are altered to quartz and alkali feldspar.

Voids (8.2\%) - unfilled voids form 30 to $40 \%$ of some pumices.

\section{ZEOLITE INTERVAL II}

(Tht) Tuff of Calico Hills

Tht-1. G1-1436 Nonwelded, zeolitized, ash-flow tuff

Pumice - pumice fragments range from nonwelded to densely welded. Pumices are very abundant in this sample, and are up to $9 \mathrm{~mm}$ long. Clays form dark brown boundaries around pumices (20 to $40 \mathrm{um}$ thick), similar to G1-1639. Large lenticutar vugs are filled by clinoptilolite laths up to $150 \mathrm{um}$ in length. Smaller vugs are partly filled with 5-to 10- $\mu$ m needles of zeolite. Often the vugs are rimmed by yellow clays, and the rest of the vug is filled with fine-grained interstitial clinoptilolite and clays. 0xides are scarce. The apparent alteration sequence from vug walls inward is (1) yellow clay, (2) massive clinoptilolite, and (3) needles of clinoptilolite. Perlite structures are also still present.

Shards - small, up to $150 \mathrm{um}$ in size. Voids are partly to fully enclosed by clinoptilolite needles that replace the surrounding shard. Typically a 20-um-thick rim of massive clinoptilolite is coated by a 10-um-thick region of acicular clinoptilolite along shard rims. Voids up to $25 \mu \mathrm{m}$ are common in the shard centers.

Groundmass - tan to dark brown. The brown color is imparted by disseminated clays. There are few oxides in the groundmass.

Phenocrysts (4.8\%). - quartz, plagioclase, sanidine, and biotite.

Accessory minerals - allanite, zircon, and apatite.

oxides $-C_{5}-C_{7}$.

Lithics (3.2\%) - same as G1-1561. 
Voids (11\%) - Voids are partly to fully infilled by zeolites and clays. Some perlitic fragments surround what is now completely void space.

Tht-2. G1-1561 Nonwelded, zeclitized, ash-flow tuff

Pumice - similar to G1-1639 - major differences are

1. clay borders are not as thick (2 to $5 \mathrm{~mm}$ average), but are still present,

2. lenticular vugs of coarse clinoptilolite are slightly more common,

3. yellow smectite is still present, but is less common ( $20 \%$ less than G1-1639), and

4. open voids are slightly more common, typically 50 to $100 \mu \mathrm{m}$ in diameter.

Shards - shards are small (100 to $150 \mathrm{~mm})$, and shard morphologies are masked by zeolitization. Shards are replaced by $5-$ to $10-\mu \mathrm{m}-10 \mathrm{ng}$ clinoptilolite needles and laths. Voids are common, 15 to $50 \mathrm{~mm}$ across.

Groundmass - same as G1-1639, although clinoptilolite may be slightly coarser here (i.e., 5- to 10-um, blocky, interlocking masses of equant crystals).

Phenocrysts (2.4\%) - quartz, plagioclase, sanidine, and biotite.

Accessory minerals - zircon and apatite.

Oxides $-\mathrm{C}_{5}-\mathrm{C}_{6}$; two rutile grains are present.

Lithics (2.8\%) - most are angular, densely welded tiff fragments that are devitrified.

Voids (5\%) - voids are partly to totally infilled by zeolites and clays.

Tht-3. G1-1639 Nonwelded, zeolitized, ash-flow tuff

Shards - difficult to recognize; they are masked by zeolitization and are the same color as the groundmass (dark honey brown). Shards are up to $100 \mu \mathrm{m}$ long, totally infilled with 5- to 15- $\mu \mathrm{m}$ clinoptilolite needles (axiolitic-type growth). Shard centers commonly contain clays and/or oxides, but a few have voids.

Groundmass - honey-brown color. The groundmass consists of fine-grained clays and clinoptilolite, with zeolite predominant. Few oxides occur in the groundmass. 
Pumice - the predominant material in this rock. Some pumice tubes are filled with massive clinoptilolite (up to 50-um crystals in lenticular vugs). Niost, however, are the same as in G1-1774 (i.e., dense intergrowths of fine-grained clinoptilolite needles and laths that almost fill vugs). Clays occur along all borders (dark brown) and are prevalent along pumice tubes.

Phenocrysts (3.6\%) - quartz, plagioclase, sanidine, and biotite.

Accessory minerals - zircon and apatite.

oxides $-C_{6}-C_{7}$.

Lithics (1.4\%) - devitrified rhyolites.

Fracture - one fracture is present, infilled by clinoptilolite.

Voids (2.4\%).

Tht-4. G1-1774 Slightly welded, zeolitized, bedded tuff

Shards - up to $300 \mathrm{~mm}$ long, bordered in all cases by yellow smectite (3to 5- $\mu \mathrm{m}$ border). Shards are altered to zeolites, typically with a 20- tc 30- $\mu \mathrm{m}$ rim of coarse crystals that grades into 10- to 20- $\mu \mathrm{m}$ sharp, blocky, lath, or needle-like terminated crystals of clinoptilolite within the shard. Voids are usually present in shard centers, but these are very small (10 to $25 \mu \mathrm{m})$.

Groundmass - fairly rare (reworked tuff), containing about equal proportions of fine-grained clinoptilolite and smectite. Smectites mantle almost every lithic fragment, phenocryst, shard, and pumice fragment. The groundmass varies in color from lemon yellow to deep brown.

Pumice - pumices vary from unaltered original structures to totally altered. A common factor is the sharply defined clinoptilolite crystals growing in vugs (20- to $35-\mu m$ crystals). Vugs may be totally filled by a mass of intergrown needles, laths, and blocky crystals. Coarse zeolites are rare in this thin section. All pumices have clay borders with clays lining interior tubes. There are also features resembling relic perlitic cracks which have altered to clinoptilolite. Original cracks are now filled with massive clinoptilolite, and once-glassy regions are now voids with infilling of large, sharply defined zeolite crystals. 
Phenocrysts (25\%) - plagioclase, quartz, sanidine, and biotite.

Accessory minerals - zircon, apatite, and monazite. oxides $-\mathrm{C}_{6}-\mathrm{C}_{7}$.

Lithics (3.0\%) - there are many different types of lithic fragments, but all are altered to quartz and alkali feldspar.

Voids (3.4\%) - unfilled voids form 15 to $20 \%$ of some pumices.

(Tcp) Prow Pass Member, Crater Flat Tuff

TCP-1. G1-1819 Slightly welded, zeolitized, ash-flow tuff

Shards - shards are up to $200 \mu \mathrm{m}$ long, clear to peach colored, and undeformed. Clear shards are altered predominantly to voids with

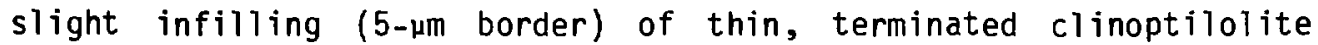
crystals. Peach-colored shards are pseudomorphed by opal. Larger shards often have two generations of zeolite: an original fine vug lining, overlaid by $100-\mu m$ spheres of coarse clinoptilolite in shard centers.

Groundmass - dark tan-brown, containing fine-grained clinoptilolite, disseminated clays, and dispersed 5 - to $10-\mu \mathrm{m}$ oxides.

Pumice - up to 2 to $4 \mathrm{~mm}$ long. Tube walls in pumices are thick $(15-\mu \mathrm{m})$ rings of coarse clinoptilolite crystals. Centers of pumice tubes are partly infilled by fine needles of zeolite. Some zeolite rings are totally filled with clays; others have voids up to $100 \mu \mathrm{m}$ wide. Once again the $\mathrm{clays}$ are obvious in elongate sections through tubes (may be thin coatings on walls). A few oxides are disseminated throughout, and pumices are often partly mantled by amorphous clays.

Phenocrysts (7.8\%) - plagioclase, sanidine, quartz, biotite, and orthopyroxene (pseudomorphs).

Accessory minerals - zircon and apatite.

oxides $-\mathrm{C}_{4}-\mathrm{C}_{6}$.

Lithics (1.4\%) - four lithic fragments are seen, devitrified to quartz and alkali feldspar, then very much altered. Some included pumices have spherulites.

Voids (2.6\%) - common in pumices and in shard centers. These are partially infilled with zeolites. 
Tcp-2. G1-1854 Partly welded, zeolitized, ash-flow tuff

Shards - light tan centers are now void, up to $250 \mu \mathrm{m}$ wide. Larger shards show two generations of clinoptilolite growth. Large equant crystals form the shard borders, then smaller (2- to 5- $4 \mathrm{~m}$ ) terminated crystals grow into central shard vugs. Smaller shards have altered entirely to fine-grained interlocking clinoptilolite crystals.

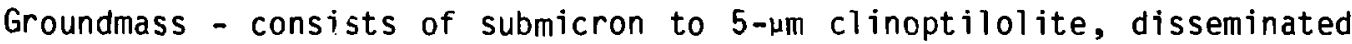
black clays, and oxides. Original shard fragments and ash in the groundmass have been zeolitized.

Pumice - slightly flattened but not aligned, and are altered to clinoptilolite, yellow smectite and oxides. Smectite borders on pumices are up to $30 \mu \mathrm{m}$ wide. Pumices are up to $3 \mathrm{~mm}$ long. Clinoptilolite appears to have filled tubes following clay formation on outer tube walls. These zeolite crystals (up to $25 \mu \mathrm{m}$ ) form interlocking

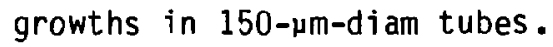

Phenocrysts (11\%) - plagioclase (oscillatory zoning common), sanidine, quartz (embayed), biotite, amphibole, and orthopyroxene (pseudomorphs).

Accessory minerals - zircon and dpatite.

oxides $-\mathrm{C}_{4}-\mathrm{C}_{6}$, including rutile.

VII. CENTRAL PROW PASS MEMBER, CRATER FLAT TUFF

ICp-3. Gl-1883 Partly welded, devitrified, ash-flow tuff

Shards - up to $300 \mu \mathrm{m}$, with axiolitic devitrification textures (i.e., fibrous $20-\mu \mathrm{m}$ borders of cristobalite and alkali feldspar). Central portions also have oxides associated with fine-grained devitrification products; otherwise, the shards are clear and have no voids. The only difference from the groundmass is slightly higher refractive index. The shards are deformed around phenocrysts.

Groundmass - tan-brown and recrystallized to interlocking patches and sprays of cristobalite and alkali feldspar. These minerals occur as 20- to 30- $\mu \mathrm{m}$ laths and as equidimensional granophyric clots. 0xide minerals (10 to $20 \mu \mathrm{m})$ are disseminated throughout.

Pumice - up to $5 \mathrm{mrn}$ long and are deformed. Border mantles are the same as in G1-1982, but may be less distinct and cross-cut original borders. Large spherulites are indistinct and have recrystallized to 
large patches of quartz and to alkali feldspar laths $(50 \mu \mathrm{m})$. In large voids, secondary spherulites often occur along the borders with central regions filled by granophyric quartz and alkali feldspar. Oxide grains are up to $200 \mathrm{\mu m}$ long and are interspersed through the pumices. Interstitial regions in lapilli are filled by very finegrained quartz or cristobalite and alkali feldspar.

Phenocrysts (16\%) - sanidine, plagioclase (oscillatory zoning), quartz (embayed), biotite, and orthopyroxene (pseudomorphs).

Accessory minerals - zircon.

Oxides $-\mathrm{C}_{3}-\mathrm{C}_{5}$, includes rutile.

Lithics (1\%) - three fragments occur, devitrified to quartz and alkali feldspar.

Void space $(0.4 \%)$.

Tcp-4. G1-1982 Partly to moderately welded, devitrified, ash-flow tuff Shards - up to $250 \mathrm{\mu m}$ long, clear in color, with small voids in their centers $(10$ to $20 \mu \mathrm{m})$. Shard centers are devitrified to cristobalite and aikali feldspar spherulites (100- $\mu \mathrm{m}$ diam). Shard borders are devitrified to the same phases but are fibrous, forming a 20 - to 30-um mantle around the shards. The shards are only sightly deformed.

Groundmass - groundmass is red-brown in color and devitrified to finegrained irregular patches of fibrous cristobalite and alkali feldspar with some associated clays. The red-brown color is due to abundant fine-grained rutile and hematite.

Pumice - pumice structures are masked by devitrification. Many large voids are due to plucking (up to $500 \mathrm{\mu m}$ ). Pumices are up to $7 \mathrm{~mm}$ in length, with rims mantled by 40-um-wide, fibrous intergrowths of cristobalite and alkali feldspar growing in from the edges (clear to peach color). Spherulites (up to 200-um diam) make up most of the lapilli interiors. Interstitial regions are made up of two dominant devitrification types:

1. fine-grained masses of cristobalite and alkali feldspar.

2. botryoidal stringers of opal replaced by chalcedony. These are commonly $50 \mathrm{\mu m}$ wide and $200 \mathrm{\mu m}$ long. Individual 
spheroids are up to $40 \mu \mathrm{m}$ in diameter. Red coloring in the lapilli is due to rutile and hematite.

Phenocrysts (11\%) - sanidine, plagioclase, quartz (embayed), and biotite. Accessory minerals - zircon and apatite.

0xides $-\mathrm{C}_{2}$, with abundant rutile crystals.

Lithics $(0.4 \%)$ - three subrounded fragments occur, altered completely to quartz and alkali feldspar.

Voids $(1 \%)$ - some voids occur in almost every shard and pumice fragment. Minerals lining the voids are quartz and alkali feldspar.

\section{ZEOLITE INTERVAL III}

Tcp-5. G1-2083 Slightly welded, zeol itized, ash-flow tuff

Shards - undeformed, up to $700 \mathrm{~mm}$ long with borders defined by refrac-

tive index differing from the groundmass. Two types are found:

1. Shards in which clear crystals line the vugs. This lining is $10 \mu \mathrm{m}$ thicx and consists of blocky, lath or needle-shaped clinoptilolite.

2. Shards in which crystals almost fill the vugs. These shards have a colorless border zone of clinoptilolite around the vugs $(20 \mu \mathrm{m}$ thick); then the same zeolite crystals as above fill the remainder. Spherical $(120-\mu \mathrm{m})$ zoned phases (mordenite?) also help in filling large vugs. Vugs in the shards are up to $200 \mu \mathrm{m}$ wide. Clays do not rim shards.

Groundmass - groundmass is tan to light tan-brown and is made up of submicron to 5-um clear grains (clinoptilolite), large formless masses of $\mathrm{clay}$, and disseminated oxides.

Pumice - pumices are up to $10 \mathrm{~mm}$ long, slightly darker brown than the groundmass. Borders $(100 \mu \mathrm{m})$ are commonly lined by clays. Clinoptilolite lines tubes and vugs in pumices while clays define the walls of the tube structures. Voids up to $250 \mu \mathrm{m}$ in diameter are present. Disseminated oxides up to $20 \mu \mathrm{m}$ wide are present in the pumices. Lapilli are abundant and are partly to heavily deformed. Phenocrysts (10\%) - plagioclase, sanidine, quartz (embayed), biotite, and orthopyroxene (pseudomorphs).

Accessory minerals - allanite, zircon and apatite.

Dxides $-\mathrm{C}_{5}-\mathrm{C}_{6}$, includes rutile (large grains). 
Lithics (0.6\%) - heavily altered, rounded fragments. Quartz and alkali

feldspar form granophyric or spherulitic devitrification.

Voids (3.8\%) - with incipient zeolite fillings.

TCP-6. G1-2166 Nonwelded, zeolitized, bedded tuff

Pumice - Pumices vary in size from 0.5 to $3 \mathrm{~mm}$, tan-brown to brown. Tube structures are intact and lapilli are subhedral to anhedral. Most pumices are altered to fine-grained, clear zeolites (clinoptilolite and mordenite) less than $5 \mu \mathrm{m}$ in size. A small percentage of the pumices is devitrified. Primary spherulites or secondary spherulite rims surround recrystallized quartz and alkali feldspar. Devitrification products are relict. There is a heavy concentration of clays along with the zeolites in lapilli. Zeolites fill open tubes, while clays line the outer walls of tubes.

Shards are not present.

Groundmass - the groundmass contains clays and oxides that have altered

to rutile. Some minor zeolites are also present.

Phenocrysts (9.1\%) - sanidine, plagioclase, and biotite. Many are

fractured and/or shattered. There are possibly some pyroxene phenocrysts in this sample, but these have been altered.

Accessory minerals - zircon and apatite.

Lithics (2.6\%) - a variety of pumice and welded-tuff fragments occur, along with recrystallized spherulite fragments and some nonwelded shard-rich fragments.

Voids $(0.4 \%)$ - voids filled in part by zeolites, clays and oxides.

(Tcb) Bullfrog Member, Crater Flat Tuff

Tcb-1. G1-2233 Slightly welded, zeolitized, ash-flow tuff

Shards - similar to 61-2247, although orange-brown borders are not prominent. Clinoptilolite crystals are slightly larger (up to 10 $\mu \mathrm{m})$, with some fibrous balls $50 \mu \mathrm{m}$ in diameter (possibly mordenite). Grour' ass - same as G1-2247.

$\mathrm{Pu}$ : - lapilli are larger and more abundant than in G1-2247, up to 6 "n long. Voids (up to $80 \mu \mathrm{m}$ ) are completely filled by massive clinoptilolite or by needles and laths of clinoptilolite. Oxides and 
clays are heavily concentrated in the lapilli, mimicking tube structure. Clays are especially localized in the pumices; otherwise the pumices are similar to G1-2247.

Phenocrysts (15\%) - plagioclase, quartz, sanidine, biotite, and horn-

blende.

Accessory minerals - zircon and apatite.

$0 x$ ides $-\mathrm{C}_{6}-\mathrm{C}_{7}$.

Voids $(2.2 \%)$ - common in shard centers and in pumices. Partial void

fillings consist of zeolites and clay.

Lithics $(0.4 \%)$ - consist of moderately welded, devitrified tuffs.

Tcb-2. G1-2247 Nonwelded, zeolitized, ash-flow tuff

Shards - up to $300 \mathrm{~mm}$ long, undeformed, with centers that are commonly unfilled voids (20 to $200 \mu \mathrm{m}$ across). Shard rims are bordered by clays and oxides imparting an orange to brown color. Infilling the voids are fine needle- to lath-shaped clear crystals (5 $\mu \mathrm{m}$ long) which form partial to full aggregates of zeolite crystals, even to the point where they fill some shard voids (mostly clinoptilolite with minor clays).

Groundmass - tan to tan-brown submicron grains of clinoptilolite, scarce dispersed oxides (to $20 \mu \mathrm{m}$ ), and clays.

Pumice - 1 to $3 \mathrm{~mm}$, undeformed, with clear and obvious tube structure. Pumices are slightly darker in color than the groundmass. Voids are infilled partly to totally by 5- to 10-um lath-like and blocky clear crystals of clinoptilolite. Pumice matrices are fine-grained clinoptilolite and clay. Oxides (10 to $20 \mu \mathrm{m})$ are disseminated through the pumices. Clays are more prominent in pumices than in the rest of the rock, and are clearly seen in the tubes.

Phenocrysts (12\%) plagioclase, quartz (embayed), sanidine, and biotite.

Accessory minerals - zircon and apatite.

oxides $-\mathrm{C}_{6}-\mathrm{C}_{7}$ includes rutile.

Lithics $(0.4 \%)$ - very heavily altered.

voids $(3.4 \%)$ - filled by zeolites. 
Tcb-3. G1-2289 Nonwelded, zeolitized, ash-flow tuff

Shards - 10 to $600 \mu \mathrm{m}$ long, orange to tan and filled by clinoptilolite.

Blocky zeolite crystals in the shards are more prominent than in

Gl-2290, and clays sometimes outline the shards.

Groundmass - lighter in color than in G1-2290, but otherwise the same.

Pumice - similar to Gl-2290, but blocky clinoptilolite crystals predom-

inate in the tube structures. Blocky zeolite crystals are up to 45

$\mu \mathrm{m}$ long, and some open void space (to $250 \mu \mathrm{m}$ ) is present.

Phenocrysts (15\%) - plagioclase, sanidine, quartz, biotite, and horn-

blende.

Accessory minerals - zircon and apatite.

Lithics (1.0\%).

Voids (1.4\%) - same as in G1-2290.

Tcb-4. G1-2290 Nonwelded, zeolitized, ash-flow tuff

Shards - clear, 10 to $400 \mu \mathrm{m}$ long. Shard rims appear black, but the colcr is due to fine $(3-\mu \mathrm{m})$ fibrous borders of mordenite with low refractive index. Shard interiors are filled with massive clear crystals of clinoptilolite. Sometimes blocky clinoptilolite or fuzzy mordenite partly infill the larger shards. All shards are undeformed. Groundmass - deep olive brown to black. Submicron to 5-um clear clinoptilolite intergrowths occur with heavy concentrations of disseminated clays and minor oxides which impart a dark red color.

Pumice - up to $10 \mathrm{~mm}$ long. Their boundaries are partly to wholly rimmed by clays and oxides. Tube structures are present; some pumices show evidence of mechanical plucking during thin section preparation. Clays and oxides are present in the lapilli as finely disseminated

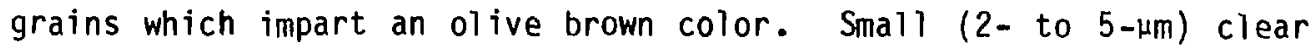
grains associated with the clays and oxides are clinoptilolite. Larger tube vugs are filled with blocky terminated clinoptilolite crystals up to $35 \mu \mathrm{m}$ long. Other large voids are filled with massive clinoptilolite.

Phenocrysts (13\%) - plagioclase, quartz (embayed), sanidine, biotite, and hornblende.

Accessory minerals - zircon and apatite.

Dxides $-C_{5}-C_{7}$, some rutile alteration. 
Lithics $(0.6 \%)$.

Voids (3.0\%) - void space is partially to totally filled by zeolites and clays.

IX. CENTRAL BULLFROG MEMBER, CRATER FLAT TUFF

Tcb-5. G1-2318 Nonwelded, devitrified, ash-flow tuff

Shards - very hard to see, because they are the same color as the matrix. Shards are deformed around phenocrysts, and are devitrified to quartz and alkali feldspar. Shards are flattened (up to $100 \mathrm{\mu m}$ long, but only 5 um thick). Their tan color is due to tinted quartz, alkali feldspar, and yellow clays.

Groundmass - slightly brown-tan to black. There are local concentrations of black clays, but the rest of the groundmass consists of finegrained cristobalite and alkali feldspar. Oxides are small and very rare.

Pumice - up to $3 \mathrm{~mm}$ long, with portions that are commonly plucked out. Spherulitic borders (i.e., radial fibrous masses of cristobalite and alkali feldspar) are up to $100 \mu \mathrm{m}$ in diameter, and spherulites may occur in central portions of pumice. The rest of the alteration may be opal (spheres $35 \mu \mathrm{m}$ in diameter, clear, isotropic), possibly with chalcedony or cristobalite. Few clays and oxides occur in the pumice. Pumices are abundant, with a high percentage of void space ( 30 to $40 \%$ ). Voids are partially filled by devitrification products. Phenocrysts (26\%) - plagioclase, sanidine, quartz (embayed), and biotite. Accessory minerals - zircon and apatite.

0xides $-C_{5}-C_{7}$, with a rutile vein of oxidation in one corner of the sample.

Lithics - none.

Voids $(4.8 \%$ ) - common in pumice (see above).

Tcb-6. G1-2363 Partly welded, devitrified ash-flow tuff

Shards - some are clear and show axiolitic textures. Some shards are $300 \mu \mathrm{m}$ long with $20-\mu \mathrm{m}-w i d e$ fibrous intergrowths of cristobalite and alkali feldspar, with oxides and clays in the center. These textures are remnant, however. Other shards are up to $500 \mu \mathrm{m}$ long with very diffuse borders. These have recrystallized from cristobalite and 
alkali feldspar fibers to form large interlocking (granophyric) grains of quartz and alkali feldspar. Many of these crystals form 50-um grains, and some approach $250 \mu \mathrm{m}$. As a result of recrystallization, many grains have crossed shard borders.

Groundmass - dark tan to brown, with submicron to 5- $\mathrm{m}_{\mathrm{m}}$ mixtures of cristobalite, alkali feldspar, disseminated black clays and oxides (up to 20 um long).

Pumice - 2 to $5 \mathrm{~mm}$ long, dark gray-brown, and slightly flattened with borders that are slightly ragged. Spherulites grow in from the edges (fibrous, clear, 100-um intergrowths of quartz and alkali feldspar). Central interstitial regions are filled with recrystallized quartz and possible alkali feldspar (100 $\mu \mathrm{m}$, roughty equidimensional, and clear). Oxides and clays are associated with recrystallization in the central regions. Voids are rare, but are up to $20 \mu \mathrm{m}$ 1ong. Some spherulites have also nucleated in the central regions. Approximately 20\% of the lapilii consists of voids, and the lapilii are slightly flattened.

Phenocrysts (20\%) - sanidine, plagioclase, quartz, biotite, and hornblende.

Accessory minerals - zircon and apatite.

Oxides $-\mathrm{C}_{5}-\mathrm{C}_{7}$.

Lithics $(0.2 \%)$.

Voids $(0.4 \%)$ - some voids are probably due to mechanical plucking during sample preparation.

Fractures - none.

Tcb-7. G1-2410 Partly welded, devitrified, ash-flow tuff

Shards - axiolitic, undeformed except around phenocrysts and then only slightly. Shards are light tan in color. Fibrous intergrowths of cristobalite and alkali feldspar radiate from the outer edges toward the shard centers. The centers of shards contain either clays, or a few disseminated oxides (most common), or patches of recrystallized quartz (rare).

Groundmass - clear to tan in color. Clear regions are mostly patches of recrystallized quartz and alkali feldspar. The borders of grains are diffuse and ragged, and individual grains range up to 50 to $200 \mu \mathrm{m}$ in 
size. Tan regions are aggregates of microcrystalline quartz, alkali feldspar, clays, and oxides.

Pumice - slight deformations and some void space, but their original structure is masked by devitrification. Spherulites up to $200 \mathrm{\mu m}$ wide are common. Often the pumice border regions have fibrous intergrowths of quartz and alkali feldspar growing towards the center, and then spherulites filling the centers. Some regions of pumice contain patches of granophyric recrystallized quartz and alkali feldspar. Borders of pumices are hard to distinguish from the groundmass because of recrystallization. The central portions of the pumices have varied stages of devitrification, from pristine spherulites to fine-grained devitrification to granophyric recrystallization. Clays and oxides are not major phases in the lapilli.

Phenocrysts (16\%) - plagioclase, sanidine, quartz, biotite, and hornblende. Glomeroporphyritic clots of feldspar and biotite are common.

Accessory minerals - zircon and apatite.

oxides $-\mathrm{C}_{6}-\mathrm{C}_{7}$.

Lithics (3.0\%) - rounded, up to $7 \mathrm{~mm}$ 1ong, and mostly fragments of devitrified rhyolitic ash flow tuffs.

Voids $(0.9 \%)$.

Tcb-8. G1-2436 Moderately welded, devitrified, ash-flow tuff

Shards - moderately scarce, small, and partly deformed, with axiolitic textures present. Shards are discernible only because of slight color variations: altered shards (up to $200 \mu \mathrm{m}$ long) are clear while the groundmass is tan-brown. Phases in the shards are colorless, fibrous crystals (to $20 \mathrm{\mu m}$ long) which fill the shards to their boundaries.

Groundmass - subhedral, interlocking, light tan to clear phases (submicron to $50 \mu \mathrm{m}$ ), with finely dispersed Fe-Ti oxides.

Pumice - from 2 to $10 \mathrm{~mm}$ long, altered to spherulites $(40 \mu \mathrm{m}$ in diameter). Plumose structures occur at shard borders. 0xides and black clays are common in the interstitial regions within pumices. Some vugs occur in the pumices, partially filled by the same phases 
that occur in the shards. Void spaces form about 5\% of the shard vol umes.

Phenocrysts (10\%) - plagioclase, sanidine, quartz, biotite, and hornblende.

Accessory minerals - zircon and apatite.

$0 x$ ides $-\mathrm{C}_{3}-\mathrm{C}_{5}$

Lithics $(0.6 \%)$.

Voids (none counted) - mostly filied by granophyric quartz and alkali

feldspar; some spherulites also occur.

Fractures - none.

Tcb-9. Gl-2476 Moderately to partly welded, devitrified, ash-flow tuff Shards - axiolitic, commonly discolored orange by the oxidation of disseminated oxides. Fibrous intergrowths of. cristobalite and alkali feidspar are up to $50 \mu \mathrm{m}$ long, and shards are up to $300 \mu \mathrm{m}$ long. The centers of shards have a variety of fillings, but are most commoniy recrystallized to patches of quartz and/or alkali feldspar and filled by oxides and dark clays. Finally, a few shards contain open voids or are filled by yellow clays.

Groundmass - masked by oxide grains (up to 5 to $20 \mu \mathrm{m}$ in diameter) which obscure the other phases. Otherwise, the groundmass contaills a mixture of recrystallization patches of quartz and alkali feldspar (up to $50 \mathrm{\mu m}$ ) and microcrystalline devitrification products of quartz. feldspar and clays.

Pumice - up to $3 \mathrm{~mm}$ long, and only slightiy deformed, Again, primary strucicures are masked by devitrification. The lapilli are often rimmed by clays. Pumices are similar to those in G1-2410 above, but large spherulites and plumose structures (about $200 \mu \mathrm{m}$ ) are much more common. Small central regions are filled by recrystallization patches of quartz and alkali feldspar. Large $(20-\mu \mathrm{m})$ clusters of clays and oxides are disseminated throughout. Rarely, recrystallization patches dominate in the pumices.

Phenocrysts (8.3\%) - plagioclase, sanidine, quartz, biotite, and hornblende.

Accessory minerals - zircon and apatite.

oxides $-\mathrm{C}_{5}-\mathrm{C}_{7}$ includes rutile. 
Lithics $(0.9 \%)$ - two dacitic lavas and three devitrified tuff fragments.

Tcb-10. G1-2486 Moderately to partly welded, devitrified, ash-flow tuff Shards - show axiolitic textures with clear to orange-brown color, and are undeformed (200 to $600 \mathrm{um}$ long). Voids are common in shard centers. Devitrification products are fibrous (up to $15 \mu \mathrm{m}$ long), perpendicular to the shard boundaries and with oxides in shard centers. Shards are slightiy deformed around phenocrysts.

Groundmass - light tan-brown, but otherwise the same as in G1-2436

(above). Groundmass crystals range from submicron to 25-um diameters. Pumice - rimmed by fine-grained oxides to give orange borders. Spherulites (100- $\mu \mathrm{m}$ diam) often nucleated on borders and grew inward. Central regions of the pumices often have some "matrix" material and dispersed oxides. Central interlocking "matrix" grains are up to 150 $\mu m$ long and occur as patches in other places in the pumices. Original pumice textures are obscured.

Phenocrysts (10\%) - sanidine, plagioclase, quartz, biotite, and hornblende.

$$
\begin{aligned}
& \text { Accessory minerals - apatite and zircon. } \\
& \text { 0xides }-c_{2} \text { to } c_{5} \text {. }
\end{aligned}
$$

Lithics $(5.2 \%)$ - other ash-flow tuff fragments that have been altered. Voids (none counted) - almost all voids are filled by quartz and alkali feldspar.

Fractures - none.

X. ZEOLITE INTERVAL IV

Tcb-11. Gl-2555 Partly to moderately welded, zeolitized, ash-flow tuff Shards - (up to. $400 \mathrm{\mu m}$ long) grade from clear rims to yellow-orange to clear centers. Rare voids are lined or filled with stubby, blocky

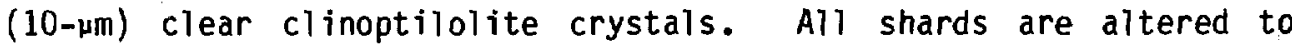
crystalline material, but the crystal edges are not clearly defined. zonation is present in the altered shards, with crystal sizes ranging from fine grained near the edges to larger near the cores. The shards are undeformed. 
Groundmass - darker brown, and altered to fine-grained, interlocking growths of low-birefringence zeolites and clays, and dispersed 1- to 10-um Fe-Ti oxides.

Pumice - pumices display original textures, have deep brown borders and range in size from $150 \mu \mathrm{m}$ to $6 \mathrm{~mm}$. They are altered to equant 2- to 10- $\mu \mathrm{m}$ colorless zeolites with clays and submicron oxide minerals. Phenocrysts (11\%) - plagioclase, sanidine, quartz, biotite, and hernblende.

Accessory minerals - apatite and zircon.

0xides $-\mathrm{C}_{6}-\mathrm{C}_{7}$.

Lithics (2.3\%).

Voids $(0.6 \%)$.

Fractures - one open fracture occurs in this thin section.

Tcb-12. G1-2600 slightly to partly welded, zeolitized, ash-flow tuff

Shards - $(100$ to $600 \mu \mathrm{m}) \mathrm{clear}$ in color with obvious zoning (2 phase).

Shard borders $(15$ to $20 \mu \mathrm{m})$ are clear; homogeneous zeolites that are either slender needles or blocky (all clear) line the vugs. Oxides are also associated with vug linings. Shards without vugs are typically altered to granular zeolites similar to the border zones of other shards.

Groundmass - cryptocrystalline, and altered to zeolites with finely dispersed Fe-Ti oxides and minor clays. The groundmass color is ol ive-brown.

Pumice - $700^{\circ} \mathrm{\mu m}$ to $2 \mathrm{~mm}$ long and darker brown than the groundmass. Original structures are retained. The centers of tubes are filled with colorless 5 - to $15-\mu \mathrm{m}$ coarsely crystalline zeolites. Tube walls are formed of finely crystalline zeolites and clays (yellow birefringence). Submicron oxides are disseminated throughout. Scarce voids (vugs) in the tube centers are lined with terminated 10 - to 15- $\mu \mathrm{m}$, slender, acicular, colorless clinoptilolite crystals.

Phenocrysts (8.8\%) - plagioclase, sanidine, quartz (embayed), biotite, and hornblende.

Accessory minerals - allanite, zircon, and apatite.

Oxides $-C_{6}$, includes rutile.

Lithics (2.0\%). 
Voids (1.4\%) - partly to fully filled by lath and wedge-shaped crystals of low birefringence.

\section{(Tct) Tram Member, Crater Flat Tuff}

Tct-1. Gl-264l Slightly to partly welded, zeolitized, ash-flow tuff

Shards - virtually impossible to distinguish, up to $40 \mathrm{~mm}$ long. Shards are slightly clearer than the matrix, and altered to equigranular clear zeolites. Minor regions of brown botryoidal stringers occur in the groundmass. Under cross-nicols these botryoidal stringers have a diffuse yellow color (possibly due to clays, with opal or chalcedony). Groundmass - light tan-brown in color, composed of submicron crystals of zeolites, clays, and disseminated Fe-Ti oxides.

Pumice - up to $6 \mathrm{~mm}$ long - brown in color and slightly flattened. Most original pumice textures are gone. Small vugs are common, lined with clear, small, 2- to 5- $\mu \mathrm{m}$ tabular and acicular crystals of zeolite. The rest of the pumices consist of a finely crystalline combination of zeolites, clays, and oxides. Pumices are recrystallized across boundaries and are aligned in this sample. Lapilli are distinctly darker than groundmass.

Phenocrysts (15\%) - plagioclase, sanidine, quartz, and biotite.

Accessory minerals - apatite and zircon.

0xides $-\mathrm{C}_{6}-\mathrm{C}_{7}$.

Lithics $(1.6 \%)$ - altered beyond recognition.

Voids (2.8\%) - very few vugs.

Tct-2. G1-2698 Slightly to partly welded, zeolitized, ash-flow tuff

Shards - from 200 to $700 \mathrm{~mm}$ long. A few shards are orange colored and altered to massive clinoptilolite. Vugs in the central shard portions average $160 \mu \mathrm{m}$ in size, and are lined with clear, slender crystals of clinoptilolite $(10 \mu \mathrm{m})$. Tails of shards show where clinoptilolite grains have intergrown. Most shards can be discerned from groundmass only by crystal growth boundaries. The shards are undeformed.

Groundmass - typically microcrystalline, with local aggregates of submicrometer crystals. The groundmass is clear to light tan and altered to clinoptilolite, with clays and disseminated Fe-Ti oxides. 
Pumice - large and partly flattened in cross section. Pumice phenocrysts are shattered, in contrast to matrix phenocrysts (pumices may be foreign). Pumices are altered to clinoptilolite, clays and oxides all as 2- to 5-um grains - no internal zoning is present. Oxides and/or clays aggregate in "flow-banding" features. Most pumices are unaltered and preserve original structures. Vugs are very common (350 to $700 \mu \mathrm{m})$. Most alteration consists of $10-$ to $35-\mu \mathrm{m}$, clear, coarsely crystalline clinoptilolite. Terminated clinoptilolite (5 to $10 \mu \mathrm{m}$ long) often lines vugs. The major alteration phases are clays and oxides in pumice matrices. Larger vugs (100 $\mu \mathrm{m}$ and more) in the pumices show two patterns: (1) clinoptilolite crystals lining vugs with late-stage mordenite crystals (clear, radially fibrous, $30 \mu \mathrm{m}$ ) overgrowing and sometimes filling vugs; (2) massive crystalline clinoptilolite forming mantles on vugs and overlain by late-stage mordenite as above. Slight amounts of clays and disseminated nuides are present in these two-stage zeolitized pumices (textures suggest that $c$ lays altered to mordenite).

Phenocrysts (10\%)-quartz, sanidine, plagioclase, and biotite.

Accessory minerals - apatite and zircon.

Oxides $-\mathrm{C}_{5}-\mathrm{C}_{7}$, includes rutile.

Lithics (1\%) - one fragment is very large and contains rounded perlitic cracks, with large circular vugs partly filled by secondary phases (zeolites and clays). Plagioclase phenocrysts are present in random orientation. Four welded-tuff fragments also occur - all intensely welded and completely recrystallized.

Voids (5.2\%) - cavities are lined with clinoptilolite and mordenite. Voids in the perlitic pumice comprise up to $50 \%$ of that fragment. Voids are only partly filled by tabular crystals. Some indication of plumose structures is also present.

XI. DEEPER PETROLUGIC ZONES

Ict-3. G1-2790 Slightly to partly welded, devitrified, ash-flow tuff Shards - clear to yellow-tan, up to $140 \mu \mathrm{m}$ long. Shards are undeformed in the groundmass, but are slightly molded around phenocrysts. In all cases, 20- $\mu \mathrm{m}$-wide borders are formed of fibrous cristobalite and alkali feldspar intergrowths. Shard centers are filled by 10- $\mathrm{m}$ 
recrystallized quartz, alkali feldspar and yellow clays in varied proportions.

Groundmass - yellow in color, with fine-grained, equant, recrystallized quartz, alkali feldspar, minor clays, and oxides $(2 \mu \mathrm{m})$.

Pumice - up to $6 \mathrm{~mm}$ long, clear to mottled brown. Minor rims consist of intergrown cristobalite and alkali feldspar; major central regions are dominated by recrystallized patches of quartz and alkali feldspar. Clays sometimes border the pumice rims, and sometimes appear as irregular patches intergrown with recrystallized quartz and alkali feldspar.

Phenocrysts (9\%) - quartz (embayed), sanidine, plagiociase, and biotite.

Accessory minerals - apatite and zircon.

Oxides $-\mathrm{C}_{5}-\mathrm{C}_{6}$.

Lithics (9\%) - range from large trachyte(?) fragment to rhyolitic fragments. Voids $(6.5 \%)$.

Fracture - stained red, and filled by oxides and clays. Little alteration besides oxidation is apparent.

Tct-4. G1-2854 Partly to moderately welded, devitrified, ash-flow tuff Shards - up to $200 \mathrm{\mu m}$, orange-brown to clear in color. Orange-brown shards are the same as in G1-2790. Clear shards have indistinct feathery borders, and are recrystallized to two or three optically continuous mineral grains that may be quartz and/or alkali feldspar (granophyric texture).

Groundmass - a light yellow-tan patchwork of recrystallized, equant (5-

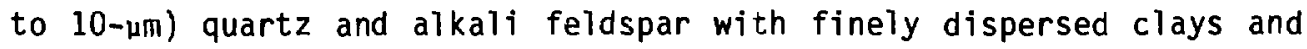
oxides.

Pumice - up to $7 \mathrm{~mm}$ long, lighter in color than the groundmass. Some lapilli have recrystallized to aggregates of equant subhedral quartz and alkali feldspar grains, with no spherulites. Most lapilli, however, have fibrous (spherulitic or plumose) intergrowths of cristobalite and alkali feldspar $(100 \mathrm{\mu m})$ radiating from the boundaries toward the centers of the pumices. Where opposing sheaves do not meet, the central voids are filled by large grains (25 to 50 
$\mu \mathrm{m})$ of recrystallized quartz and alkali feldspar (very little associated clay).

One large region of the sample is altered to clays and oxides to the point where they encroach on phenocrysts. Clays also occur as distinct streaks across the sample.

Phenocrysts (12\%) - quartz, sanidine, plagioclase, and biotite.

Accessory minerals - apatite and zircon.

0xides $-\mathrm{C}_{5}-\mathrm{C}_{6}$.

Lithics (2.0\%) - consists of three heavily altered dacitic fragments (up to $4 \mathrm{~mm}$ long) and five rhyolitic fragments. Voids $(3.4 \%)$.

Tct-5. G1-2868 Densely welded, devitrified, ash-flow tuff

Shards - 50 to, $200 \mu \mathrm{m}$, clear to orange and undeformed, but aligned oxides or clays form common rims around shards. Shards are devitrified to extremely fine grained quartz and alkali feldspar such that the shards look optically continuous. Many shards show axiolitic textures. The shards are attenuated and wrapped around phenocryst edges.

Groundmass - light tan, altered to fine-grained (2- to 7- $\mu \mathrm{m}$ ) devitrification products of cristobalite and alkali feldspar. Clays and oxides occur in large masses (10 to $100 \mu \mathrm{m}$ ) disseminated throughout the groundmass.

Pumice - 1 to $8 \mathrm{~mm}^{\circ}$ in length, and all have large vugs up to $2 \mathrm{~mm}$ in length. Growing into these vugs are spherulites $(100$ to $500 \mathrm{\mu m}$ in diameter) which in extreme cases fill the vugs, but do not cross vug boundaries. These spherulites typically grow from the borders into the pumice cores. Some interstitial regions between spherulites are composed of coarse, granular, clear phases (cristobalite and/or alkali feldspars up to $60 \mathrm{um}$ long). Spherulites formed before the large granular devitrified products.

Phenocrysts (14\%) - quartz (embayed), sanidine, plagioclase, and biotite. Accessory minerals - apatite and zircon. oxides $-\mathrm{C}_{6}-\mathrm{C}_{7}$. 
Lithics (4.4\%) - five to six fragments, once angular, now rounded on all points. No textures or primary minerals are left. The lithic fragments are completely altered to secondary minerals.

Voids (3.6\%) - Most voids occur in pumices, and voids are always partially filled by secondary minerals (cristobalite and feldspars) in the form of spherulites.

Tct-6. G1-2901 Densely welded, devitrified, ash-flow tuff

Shards - same as G1-2868, although shard borders are now less distinct with a more feathery appearance. This is due to encroachment by fibrous devitrification products (clays and oxides) in the groundmass. Typically, the interfingering region between groundmass and shards is 5 to 10 wri wide along the shard boundaries. Shards are aligned and slightly deformed in the matrix, and are highly deformed next to phenocrysts and pumices.

Groundmass - same as 61-2863, although clays and oxides are now concentrated around shard horders.

Pumice - 0.5 to $6 \mathrm{~mm}$ long, with vugs up to $1 \mathrm{~mm}$ (same as G1-2868). Spherulites are 150 up to $300 \mu \mathrm{m}$ across. Interstitial regions are filled as in Gl-2868 (calcite fills voids). Oxides and clays are concentrated into interstitial regions. All lapilli are flattened or deformed.

Phenocrysts (15\%) - quartz (embayed), sanidine, plagioclase, and biotite. Accessory minerals - apatite and zircon.

Oxides $-\mathrm{C}_{6}-\mathrm{C}_{7}$.

Lithics (2\%) - same as in Gl-2868.

Voids (1.4\%) - occur mostly in pumices, with a small amount in shards. Voids are filled by authigenic minerals that leave vugs, or they are completely filled by spherulites. About $60 \%$ of vugs are lined by calcite.

Fractures - two major fractures occur, both of which are filled by calcite.

Ict-7. G1-2937 Moderately to densely welded, devitrified, ash-flow tuff Shards - similar to G1-2854, although these shards are slightly larger and are always bounded by $\mathrm{clays}$ and/or oxides. 
Groundmass - tan, similar to G1-2854, although clays and oxides are very prevalent and the recrystallized phases are smaller in grain size. Pumice - similar to G1-2854. These pumices are now bounded by oxides and clays, and fibrous intergrowths radiating in toward the pumice centers are larger (up to $250 \mathrm{\mu m}$ ) and more distinct. Recrystallization materials fill the central regions left open by fibrous quartz and alkali feldspar.

Phenocrysts (12\%) - quartz, sanidine, plagioclase, and biotite.

Accessory minerals - apatite and zircon.

Oxides $-\mathrm{C}_{6}-\mathrm{C}_{7}$.

Lithics $(1.9 \%)$ - fragments of four dacites, two altered trachytes, and four densely welded ash flows. Voids $(0.5 \%)$.

Tct-8. G1-3001 Densely welded, devitrified, ash-flow tuff Shards - Shard outlines are visible only because of Becke-line interference at high magnification. Shards are altered to fibrous clear phases (cristobalite and alkali feldspars), $15 \mu \mathrm{m}$ long, which grow perpendicular to shard boundaries. Shard cores rarely have orange centers. Fibrous materials grow from shard edges in toward centers (axiolitic features). Opaque minerals are sometimes in the centers of shards. Shards are heavily deformed and flattened. Groundmass - light tan, with fine-grained cristobalite and alkali feldspars (submicron to $5 \mu \mathrm{m}$ ), and fine fibrous intergrowths of the two. Possible incipient spheres or spherulites are also seen. Clays and oxides are widely dispersed.

Pumice - Three types of alteration prevail in pumices: (1) spherulites only, (2) spherulites and small spheres (size 1 to $5 \mathrm{~mm}$, impossible to determine if alteration crosses boundaries), and (3) common

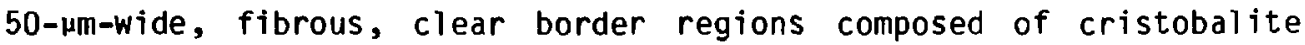
and alkali feldspar, leaving the rest of the vug region filled with 10- $\mu$ m equidimensional clear crystals of cristobalite and alkali feldspar. Centers of secondary grains typically show nucleation centers of some type. The "spheres" range from 5 to $25 \mu \mathrm{m}$. Pumice devitrification ranges from spherulite (up to 50 um in diameter) only, through spherulites and spheres to case (2) above, where 
spheres are common and isolated spherules are often seen in central regions. Regardless, spherulites $(50 \mu \mathrm{m})$ nucleate along pumice boundaries and radiate into the pumices in all instances. Equidimensional grains may be late-stage recrystallization of spherulites to individual cristobalite and alkali feldspar grains. Often, clays and/or oxides concentrate toward the centers of pumices. Lapilli are flattened and are very convolute at their edges; therefore, there is little pore space left.

Phenocrysts (1.5\%) - quartz (embayed), sanidine, plagioclase, and biotite.

Accessory minerals - zircon and apatite.

0xides $-\mathrm{C}_{5}-\mathrm{C}_{7}$.

Voids (6.4\%) - all void space has been partly to fully filled by authigenic minerals. Replacements are spherical, tabular and wedge shaped. Spherules are also common.

Lithics $(5.4 \%)$ - 13 dark brown to black lithic fragments $(0.5$ to $15 \mathrm{~mm})$ occur. Lithic size is too fine for mineral identification (severe alteration). One light-colored fragment is present, with a groundmass of trachytic plagioclase and phenocrysts of plagioclase (five megacrysts), olivine (one altered grain) and one mica (possibly a phlogopite megacryst). The groundmass of this fragment is coarser than that of a tuff. This fragment (light colored) is $4 \times 4 \mathrm{~mm}$.

Ict-9. G1-3116 slightiy to partly welded, zeolitized, lithic-rich, ash-flow tuff

Shards - clear in color, altered to vug cores with ragged outlines (100 to $300 \mu \mathrm{m})$. Due to zeolitization, the shard borders are typically granular, with clear clinoptilolite $(5 \mu \mathrm{m})$; $25-$ to $30-\mu \mathrm{m}$ terminated clinoptilolite crystals project into the centers of the vugs. The tails of the shards are completely infilled; only the centers are commonly open. Late-stage analcime is present in larger vugs (75 to $100 \mu \mathrm{m})$, and clays and oxides partially mantle the shards. The shards are slightly deformed and flattened.

Groundmass - ranges from light tan to brown, and is altered to very fine (submicron to 2-um) clear grains of clinoptilolite and analcime. 
Oxides are disseminated throughout, and aggregate with clays in patches up to $100 \mu \mathrm{m}$ across. Clays are also finely disseminated. Pumice - 1 to $7 \mathrm{~mm}$ in length, partly deformed, with most original structure gone. Voids are up to $500 \mathrm{~mm}$ across in larger pumices. Gray-brown in color, most pumices have fine-grained alteration to zeolites, with vugs infilled in the same way as shards. Clays mimic the original tube structures. 0xides up to $20 \mu \mathrm{m}$ are disseminated in the pumices. A good deal of pore space is left in the voids. Phenocrysts (12\%) - quartz, plagioclase, sanidine, and biotita.

Accessory minerals - allanite, apatite, and zircon.

0xides $-\mathrm{C}_{6}-\mathrm{C}_{7}$, includes rutile.

Lithics (21\%) - fragments of welded devitrified tuffs common (5 to 10 $\mathrm{mm}$ ), also possible dacite, basalt, and rhyolite. Shapes vary from very angular to very rounded. The predominant mineral in the lithics is feldspar, ranging from unaltered euhedral to completely altered anhedral crystals. One fragment has perlitic cracks and euhedral feldspar. The edge of this lithic fragment is obliterated. Another lithic fragment has anhedral trachytic plagioclase. Still other lithics are welded devitrified tuffs with spherulites and alteration products.

Voids (4.6\%) - Some voids are infilled by authigenic phases, but these phases fill no more than $40 \%$ of the voids. Most infilling phases are needle and lath shaped (clinoptilolite) with a few wedge-shaped crystals (analcime).

Ict-10. G1-3196 Nonwelded, zeolitized, lithic-rich, ash-flow tuff

Shards - 200 to $500 \mu \mathrm{m}$, with boundaries that are very sharp. Shards are replaced by clear clinoptilolite. Undeformed clinoptilolite crystals grow from shard borders into shard centers. Single crystals are up to $75 \mu \mathrm{m}$ long. Shard interstices are filled with clays and oxides (no void space left). The shards are absolutely undeformed, such that shapes of bubble walls and full bubbles are intact.

Groundmass - gray to brown in color (very pale), consisting of a very fine grained mix of clinoptilolite and clays (submicrometer to $2 \mu \mathrm{m}$ ). 5- to 10-um oxides are dispersed in the groundmass, but oxide megacrysts $(60 \mu \mathrm{m})$ al so occur. 
Pumice - 1 to $5 \mathrm{~mm}$ long, yellow-tan in color. Pumice borders are very fine grained analcime. Tube voids are now filled with 15- to 20- $\mu \mathrm{m}$ analcime crystals growing into the centers, as in the shards. Large individual analcime crystals grow only where voids were originally present. Otherwise, pumices have altered to equant, colorless, 5- to 10- $\mu \mathrm{m}$ analcime with disseminated clays and oxides. Phenocrysts $(9 \%)$ - plagioclase, quartz, sanidine, and biotite.

Accessory minerals - apatite and zircon.

Oxides $-\mathrm{C}_{6}-\mathrm{C}_{7}$.

Lithics (27\%) - very abundant in this sample, the most predominant type is a plagioclase-rich lava fragment (dacite?) in which the cores of plagioclases are missing. The other predominant type is a quartz recrystallization of spherulites. In all cases, mafic minerals are pseudomorphed by clays and/or oxides. These fragments are angular to subangular.

Voids $(0.8 \%)$ - very rare in the tuff groundmass, as most spaces are filled by analcime and clay. In lithics, up to $10 \%$ void space occurs where mafic minerals are altered out.

Fractures - hairline cracks are common in one-third of this sample. Fractures often are not sealed, and the walls of cracks are altered. Fractures are filled by variable proportions of clay, analcime, and silica (of different morphologies).

Tct-11. G1-3258 Nonwelded, zeolitized, lithic-rich, ash-flow tuff

Shards - same size and alteration as in G1-3196, but in small shards there is no void space for clays or oxides - clinoptilolite crystals are more compact, and completely fill the shards. Large shards are exactly like those in G1-3196. Shards are usually large, undeformed and have no void space.

Groundmass - same as in 61-3196, but darker gray-brown - clays and oxides are now obviously concentrated into the groundmass. $\mathrm{Clinoptilolite}$ is approximately equal in proportion to $\mathrm{clays}$ and other minerals in the groundmass.

Pumice - (1 to $4 \mathrm{~mm}$ ) same as in 61-3196, although more clays are present. Many lapilli are dissected by cracks that are unseated. 
Phenocrysts (10\%) - quartz, sanidine, plagioclase, and biotite.

Accessory minerals - allanite, apatite, and zircon.

Oxides $-C_{6}-C_{7}$.

Sulfides - two phases (rich golden yellow and blue-yellow in reflected light) are present; both are cubic. They fill some voids and cracks.

Lithics (20\%) - all lithic fragments are rimmed by calcite.

1. Large anhedral fragment with decomposed plagioclase which is partly rimmed by calcite and clays.

2. Perlitic fragment with large feldspar and biotite crystals.

3. Dacite fragment with large poikilitic biotite has coreless plagioclase.

Voids (none hit in point count) - some open voids occur in the pumices, otherwise voids and fractures are filled with zeolites, clays, calcite, and sulfides. The shard voids may be due to-plucking of zeolite during sample preparation.

Tct-12. G1-3321 Nonwelded, zeolitized, lithic-rich, ash-flow tuff

Shards - peach color, 100 to $500 \mu \mathrm{m}$ long with sharp borders. Smaller shards are altered to euhedral grains of clinoptilolite and analcime (up to $30 \mathrm{~mm}$ long); larger shards have larger grains of analcime (75 to $100 \mu \mathrm{m}$ ) with interstices filled by clays and oxides. Open vugs occur in some shards (up to $150 \mu \mathrm{m}$ ). Shards are undeformed.

Groundmass - fine grained, tan, with a submicron to $5-\mu m$ mix of zeolites, clays, and disseminated oxides. Clays make up a large proportion of the matrix.

Pumices - rare, up to $2 \mathrm{~mm}$ long and 01 ive-brown with the original structures gone. Pumices are replaced by interlocking masses of 10to 15- $\mu \mathrm{m}$ zeolites. Clays define the pumice borders and appear with oxides within the pumices where there are discrete random zones of zeolite only and clays only. Tube structures are gone. The lapiliti have abundant phenocrysts.

Phenocrysts (12\%) - quartz, sanidine, plagioclase, and biotite.

Accessory minerals - allanite, apatite, and zircon.

0xides - mostly $C_{1}$, al though large skeletal crystals are $C_{2}$. 
Litinic

Hics (23\%) - numerous angular fragments occur with rounded edges. All mafic minerals but biotite are now gone. Most fragments have analcime in void areas. Large zoned feldspars occur in some fragments. Most fragments are also altered to fine-grained authigenic minerals.

Voids (2.2\%) - The random distribution of some voids without obvious infilling leads one to suspect mechanical plucking during sample preparation.

Tct-13. G1-3371 Nonwelded, zeolitized, lithic-rich, ash-flow tuff

Shards - clear in color, with sharp boundaries. About 50\% are plucked out. Shard sizes range from $200 \mu \mathrm{m}$ to $1 \mathrm{~mm}$, and the shards are undeformed. Two types of replacement are present: (a) alteration to analcime only, with equant crystals up to $100 \mathrm{\mu m}$ long, and (b) alteration to analcime and clays. Clays form continuous rings halfway into the shards and mimic the outer boundary. Textures suggest axiolitic growth first, then alteration to analcime. Therefore in case (b) the sequence from edge to core is analcime, clay, analcime. Voids are rarely present in shard centers; those that occur are up to $50 \mu \mathrm{m}$ across.

Groundmass - tan to light brown in color, a mixture of submicron analcime, clays, and disseminated oxides.

Pumice - rare, up to $4 \mathrm{~mm}$ long and deeper brown than the matrix. Pumices are badly plucked; what remain are analcime, clays, and minor oxides. Very fine grained clays seem dominant and mimic tube structures. A few spherulites are present.

Phenocrysts (6.4\%) - quartz (embayed), sanidine, plagioclase, and - biotite. $\therefore$

Accessory minerals - allanite, apatite, and zircon.

Oxides $-\mathrm{C}_{1}-\mathrm{C}_{2}$, in lithics, $\mathrm{C}_{2}-\mathrm{C}_{4}$.

Lithics (37\%) - crystals of plagioclase in the lithics often have oscillatory zonation. Mafic crystals are gone or are heavily altered, but biotite is fairly fresh. Alignment of feldspar crystals is strong.

Voids (none hit during point count).

Fracture - one very large fracture occurs, filled with analcime. 
Tct-14. G1-3500 Slightly to partly welded, zeolitized, lithic-rich, ash-flow tuff

Shards - same as in G1-3371, although more shards are plucked, possibly $75 \%$. The shards are a bit smaller (100 to $900 \mu \mathrm{m})$, and type (b) analcime p? us $\mathrm{clay}$ replacement predominates.

Groundmass - dark brown to tan, with submicrometer mix of analcime,

clays, and oxides. $\mathrm{Cl}$ ays are abundant and impart the color.

Pumices - rare, up to $5 \mathrm{~mm}$ long (as in G1-3371).

Phenocrysts (10\%) plagioclase, sanidine, quartz, and biotite.

Accessory minerals - allanite, apatite, perrierite, and zircon. Oxides $-\mathrm{C}_{1}-\mathrm{C}_{2}$.

Lithics (34\%) - fragments are numerous, fairly rounded, and altered to alkali feldspar, quartz, and spherulites. The cores of some plagioclase crystals are missing. Recrystallized spherulites occur. Four dacitic lithics are present. Calcite is present in one fragment. Many fragments are altered to very fine grained material (zeolites?). Voids $(0.2 \%)$ - probabiy diue to plucking.

Fractures - sealed with various proportions of quartz, clays, and oxides.

\section{(Tr) Dacite Flow Breccia}

Ir-1. G1-3598 Partially zeolitic and partially devitrified flow breccia

This sample appears to be a fault breccia of a latite. For the sequence and description of vein fillings, see below. Opal is present as a secondary alteration product in veins. Oxyhornblende is present in the groundmass. Large lath-shaped crystals in the veins have oxides oriented along cleavage, which imparts the sample's reddish color.

Vein fill - the last material to infill the vein was calcite in the vein center. The apparent sequence of vein filling is:

1. yellow clays and minor oxides,

2. botryoidal opal,

3. a fibrous to feathery, clear, low-birefringent mineral (zeolite?),

4. lath-shaped large orange-brown crystals of clinoptilolite, and

5. calcite.

The groundmass of the lava is gray-brown, finely crystalline (up to 5 $\mu \mathrm{m})$ with clear and black grains. The original lava was abruptly quenched to produce the crystalline groundmass. No obvious 
alteration zones occur around the veins. The veins are up to $750 \mu \mathrm{m}$ wide; the orange-brown clinoptilolite laths are up to $350 \mu \mathrm{m}$ long. The opal mantle is $10 \mu \mathrm{m}$ thick on the vein walls. White sprays of fibrous zeolite (up to $150 \mu \mathrm{m}$ long) radiate from vein walls and from nucleation points within the veins (the zeolite is always associated with opal).

Phenocrysts (12\%) - plagioclase, hornblende, clinopyroxene, and orthopyroxene.

Accessory minerals - apatite and zircon.

0xides - both cubic and rhombohedral; $C_{2}-C_{3}, R_{2}-R_{3}$.

Voids (none hit during point count).

\section{Tr-2. G1-3658 Fractured devitrified flow breccia}

Under crossed nicols, large regions have perlitic cracks, and the regions with perlitic rings are altered to yellow clays. Circles within cracks commonly show color zoning, with a bright yellow border region grading to riurky gray-yellow centers. Perlitic cracks are commonly 300 to $500 \mu \mathrm{m}$ in diameter. Alteration is more prominent in regions devoid of veins. One unaltered region is almost black (glassy), with disseminated, oriented crystals and oriented yellow clays.

In plain light, fine-grained clear crystals up to $10 \mathrm{\mu m}$ long are oriented in the groundmass. The groundmass is a rich mustard-yellow to bleached yellow; these colors do not correspond to alteration around the perlitic cracks. Most of the groundmass is altered to black or yellow clays.

Groundmass - The groundmass is cryptocrystalline, with minute crystals that are yellow in crossed nicols (clays). All fractures are sealed and the filling is isotropic (analcime). The groundmass plagioclase grains are twinned and are aligned due to flowage.

Phenocrysts (20\%) - plagioclase, orthopyroxene, hornblende, and clinopyroxene.

Accessory minerals - apatite and zircon.

Oxides $-\mathrm{C}_{1}-\mathrm{C}_{4}$; ilmenite exsolution has a herringbone pattern. 
Glomeroporphyritic clots are common and the assemblages include:

1. plagioclase, orthopyroxene, oxides

2. plagioclase, oxides, and hornblende.

Voids (none hit during point count).

Ir-3. G1-3706 Devitrified flow breccia

This thin section has portions of unreacted dacite, a fault, and associated breccia. In the unreacted flow portion, the mineralogy of the lava is the same as in G1-3658. However, the groundmass is just beginning to show alteration to yellow clays and the number of perlitic cracks is much lower. In the breccia there is very good evidence for cataclasis (i.e., rotation of blocks, with angularity near intact pieces and rounding farther away). Once again, pieces of the flow are not reacted at all except for their borders.

Vein filling - The materials and sequence are the same as in G1-3598. Local differences are the absence of calcite, and some partial reaction of opal to chalcedony.

Phenocrysts (19\%) - plagioclase, hornblende, clinopyroxene, and orthopyroxene.

Accessory minerals - apatite.

Voids (none hit during point count).

Tr-4. G1-3850 Zeolitized flow breccia

This thin section is similar to the flow breccia described above. One-half of the section shows intact lava blocks, separated by a vein and from the other half in which there are shattered phenocrysts, rotated fragments, and erosion of fragment edges. The mineralogy of phenocrysts in the lava remains the same. However, there are kelephytic rims on ferromagnesian phases. In the groundmass, glass and the microcrystalline fabric have altered to clays. There are abundant vesicles in this portion of the lava flow (up to $750 \mathrm{um}$ across). One vesicle is filled with chlorite. Numerous veinlets web the undisturbed portion of section. These veins are filled with clays, minute highly oxidized Fe-Ti opaque minerals and minor chlorite. 
Vesicle fillings - Vesicle fillings are (1) a 5- to 10- $\mathrm{m}$ skin of opal, altered to chalcedony, which mantles the vesicle; (2) a 50- $\mu$ m-wide yellow band of clinoptilolite, with yellow clays growing perpendicular to walls, which overlies the opal; (3) finally, the vesicle, which is infilled with clinoptilolite, higher amounts of clays, and a relatively high oxide content (red brown). This same sequence also fills veinlets.

Major fracture - One major fracture is filled by (1) a thin (10-20- $\mu \mathrm{m})$ rind of clear clinoptilolite. In areas the clinoptilolite grows to lath-shaped gray-orange crystals, followed by (2) a calcite vein 300 um wide. Yellow clays, oxides, and minor chlorite bound the fracture. These clays may be contemporaneous with clinoptilolite, or they may be unassociated alteration products from migrating fluids.

In the shattered half of the lava, heavy veinlet webbing pervades the sample. These veinlets are filled with the same mineral sequence as the vesicles. Infrequently, calcite fills the central regions. In large void regions, zoned diamond-shaped crystals have grown. Since emplacement, these have been replaced by calcite.

Phenocrysts (18\%) - plagioclase, hornblende, clinopyroxene, orthopyroxene, and biotite.

Accessory minerals - apatite.

Voids (none hit during point count).

(TIr) Tuff of Lithic Ridge

Il $r-1$. G1-3940 Argillized bedded tuff

This sample is heavily fractured and altered to clays (30\%) and minor zeolites. Fractures are filled mainly with clays or rarely, clinoptilolite. Lithic fragments are abundant. No shards exist, and pumice verification is tenuous. What may have been pumices are extremely plucked and have altered to clays. The color of the matrix is yellow-brown to deep brown.

Phenocrysts (16\%) - plagioclase, biotite, and hornblende.

Accessory minerals - apatite, sphene, zircon, and perrierite.

Lithics (6.8\%).

Voids $(0.3 \%)$. 
Tlr-2. G1-3997 Nonwelded, zeolitized, lithic-rich, ash-flow tuff

Shards - undeformed, up to $600 \mu \mathrm{m}$ long with sharp boundaries. The shards are completely replaced by clear analcime.

Groundmass - dark tan-brown, a fine-grained (1- to 5-um) aggregate of analcime, clays, and oxides.

Pumice - up to $4 \mu \mathrm{m}$ long, undeformed, with structures intact and lighter in color (tan) than the groundmass. Pumices are mostly replaced by analcime and clays, in the same fashion that clinoptilolite and clays replace other pumices higher in the volcanic section. Other alteration phases in the pumices are oxides and chlorite. Chlorite, although rare in the pumices, is seen at this depth in pumices only and not in the groundmass. The lapilli are commonly plucked.

Phenocrysts (14\%) - sanidine, plagioclase, quartz, and biotite. Most plagioclase phenocrysts have feathery edges with a $10-$ to $40-\mu \mathrm{m}$ region of overgrowth (albitization). Plagioclase cores are commonly mottled, wormy, or missing.

Accessory minerals - sphene, apatite, zircon, and perrierite.

oxides $-\mathrm{C}_{2}-\mathrm{C}_{6}$. Low oxidation results in sandwich and "atoll" exsolution composites.

Lithics (13\%) - numerous altered trachytes, dacites, and many rhyolites, including spherulite pieces and devitrified fragments.

Fracture - one fracture is filled with clays now altering to chlorite. Voids (4.8\%).

Tlr-3. G1-4095 Nonwelded, zeolitized, lithic-rich, ash-flow tuff

Shards - same as in G1-3997.

Groundmass - similar to Gl-3997. Some clays are altered to chlorite, but only a small percentage. There are also minor small crystals of albite. This sample shows the first textural evidence of the reaction analcime + quartz + albite in groundmass mineralogy.

Pumice - similar to those in 61-3997, but with a higher abundance of dark clays. These clays seem to be altering to chlorite. There also is possible albite alteration in the pumices.

Phenocrysts (10\%) - plagioclase, sanidine, quartz, and biotite. The feldspars are similar to G1-3997 in that they have feathery overgrowths. Albite overgrowths are larger (40 to $100 \mu \mathrm{m})$. 
Accessory minerals - sphene allanite, apatite, zircon, and perrierite.

Oxides $-C_{6}$.

Lithics (26\%) - lithic fragments are abundant, including one severely altered lava fragment similar to the lava in the $3700-$ to $3800-f t$ interval. There are also two trachytes, two dacites, and numerous rhyolite fragments (all show devitrification).

voids $(1.7 \%)$.

Tlr-4. G1-4208 Nonwelded, zeolitized, lithic-rich, ash-flow tuff

Shards - up to $700 \mu \mathrm{m}$, replaced by analcime, with sharp boundaries and no deformation. There are three stages of alteration in the larger shards - fine-grained albite (feathery on the shard borders), a 5to 10- $\mu \mathrm{m}$ layer of clays and oxides, and finally large analcimes and clays.

Groundmass - similar to G1-3997, but slightly lighter in color with a higher percentage of oxides. Albite is al so present.

Pumice - up to $3 \mathrm{~mm}$ long, light brown to clear, with indistinct boundaries - the outer pumice edges are composed of feathery crystalline phases (zeolite or albite?). The inner regions are composed of analcime and clays. The clay-to-chlorite transition is slightly more pronounced than before.

Phenocrysts (10\%) - sanidine, plagioclase, and biotite. Plagioclase phenocrysts have more definite albite overgrowths (up to $100 \mu \mathrm{m}$ ) than previous samples.

Accessory minerals - sphene, allanite, apatite, and zircon.

Oxides $-\mathrm{C}_{5}-\mathrm{C}_{6}$.

Lithics (39\%) - lithic fragments are numerous, large, and rounded. They range from vesicular dacites and trachytes to devitrified rhyolites. All have some chlorite alteration, commonly a chlorite border rim. Fractures - there is one small fracture, calcite filled. Voids (none hit during point count). 
Tlr-5. Gl-4295 Non-to slightly welded, zeolitized, lithic-rich, ash-flow tuff

Shards - similar to Gl-4208, except that borders of the shards are now more ragged and albite crystals protrude into the central vugs. Groundmass - light tan-yellow, composed mostly of equant grains of interlocking analcime and albite (5 to $10 \mu \mathrm{m})$. Clays and oxides are much more disseminated than before.

Pumice - up to $4 \mathrm{~mm}$ long, relatively undeformed, and light tan to clear. The pumices are mostly replaced by fine-grained albite, analcime, and yellow clay. Some clays are altered to chlorite. (The zeolites fill the pumice tubes, whereas the clays line the tube walls.) Large central regions of the pumices are filled by analcime or calcite.

Phenocrysts (12\%) - sanidine, plagioclase, and quartz.

Accessory minerals - sphere, apatite, zircon, allanite, and perrierite.

0xides $-\mathrm{C}_{5}-\mathrm{C}_{6}$.

Lithics (19\%) - lithic fragments are large and rounded, with compositions the same as in G1-4208. Voids $(0.9 \%)$ - calcite commonly fills vugs and veinlets.

Ilr-6. Gl-4341 Non- to slightly welded, zeolitized, lithic-rich, ash-flow tuff

Shards - two types occur, both undeformed:

1. Shards replaced by analcime \pm clays, typically very large grains with clean borders, and

2. Shards with less distinct borders, with lath-shaped crystals (albite) growing toward their centers, and the rest infilled by analcime or vacant.

Groundmass - same as in G1-4295.

Pumice - same as in G1-4295.

Phenocrysts (13\%) - plagioclase, sanidine, quartz, and biotite. Most

feldspars have overgrowths of albite.

Accessory minerals - sphene, allanite, apatite, zircon, and perrierite.

oxides $-C_{6}$. 
Lithics (10\%) - fragments of dacite, trachyte, and numerous devitrified rhyolites.

Voids $(0.4 \%)$ - calcite, commonly filling voids, also fills three en echelon veins.

Tlr-7. Gl-4400 Non- to slightly welded, zeolitized, lithic-rich, ash-flow tuff

Shards - up to $400 \mu \mathrm{m}$; most shard centers are filled by epoxy. Shards are undeformed, with ragged boundarics. Typically, a thin skin of terminated albite and analcime crystals (5 to $15 \mu \mathrm{m}$ ) have grown towards center. Rarely, analcime fills the shards (as in Gl-4341).

Groundmass - same as in G1-4295.

Pumice - in most cases, the pumices are bordered by yellow clays. The main part of all lapilli is a mixture of albite, analcime, and clays (same morphology as in G1-4295). Calcite is present in some pumices. Phenocrysts $(10 \%)$ - sanidine, plagioclase, quartz, and biotite. The biotites are often associated with feldspars in glomerophyritic clots. Accessory minerals - apatite, zircon, sphene, allanite, and perrierite. oxides $-\mathrm{C}_{5}-\mathrm{C}_{6}$.

Lithics $(17 \%)$ - lithic fragments are numerous and range from dacite to rhyolite. Most are devitrified rhyolites. Voids $(7.1 \%)$ - some vugs and veinlets are filled by calcite.

Ilr-8. Gl-4503 Non-to slightly welded, zeolitized, lithic-rich, ash-flow tuff

Shards - same as in G1-4400.

Groundmass - light tan to brown, with equant acicular grains of albite and analcime. The groundmass also contains minor clays and about $5 \%$ oxides ( $\mathrm{Fe}$ and $\mathrm{Mn}$ ).

Pumice - undeformed and clear in end section. Albite and analcime fill the tubes, and clays iine the tube walls. The lapilli are up to $3 \mathrm{~mm}$ long. Minor amounts of clay, altered to chlorite, occur within the pumices. 
Phenocrysts (9\%) - sanidine, plagioclase, quartz, and biotite. Plagioclase commonly has albite overgrowths that are up to $100 \mu \mathrm{m}$ thick.

Accessory minerals - apatite and zircon.

Oxides $-\mathrm{C}_{6}$.

Lithics (20\%) - same as in G1-4400. Many lithic fragments have been partially chloritized.

Voids (1.3\%) - most voids are filled by calcite.

Fractures - many veinlets filled by clays are partially altered to chlorite + oxides.

Ilr-9. G1-4612 Nonwelded, zeolitized, lithic-rich, ash-flow tuff

Shards - clearly defined, undeformed, and up to $400 \mu \mathrm{m}$ long. Shards are

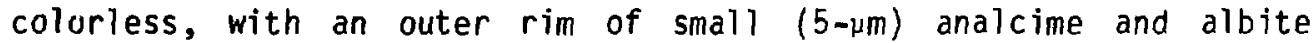
crystals, and with massive analcime interiors.

Groundmass - dark brown to black, composed of analcime + albite (50\%) and clays + oxides (50\%). All phases occur as submicron to 5-mm crystals. Calcite randomly infills some regions.

Pumice - up to $8 \mathrm{~mm}$ long, undeformed, and rimmed by oxides and clays. The replacement textures are typical (i.e., zeolites within tubes, clays lining tube walls). Fine-grained analcime and albite coat the clay-lined walls, and large crystals of albite and analcime fill voids. Some void space is also filled by calcite, while some clays are altered to chlorite.

Phenocrysts $(9 \%)$ - plagioclase, sanidine, quartz, and biotite. Some feldspar grains starting to alter (i.e., disequilibrium with rock matrix).

Accessory minerals - allanite, apatite, and zircon.

0xides $-\mathrm{C}_{5}-\mathrm{C}_{6}$.

Lithics (30\%) - one large dacite(?) fragment occurs. Other lithics are the same as in G1-4400.

Voids (none hit during point count).

Tlr-10. G1-4700 Slightly welded, zeolitized, lithic-rich, ash-flow tuff Shards - similar to Gl-4612; however, the centers of some shards are voids filled by epoxy. 
Groundmass - similar to G1-4612; however, the total percentage of clays and oxides is now slightly higher.

Pumice - up to $7 \mathrm{~mm}$ long and similar to those in G1-4612.

Phenocrysts (7.1\%) - plagioclase, sanidine, quartz, and biotite.

Accessory minerals - apatite, zircon, and perrierite.

0xides $-\mathrm{C}_{6}$.

Lithics $(19 \%)$ - lithic fragments include three heavily altered dacites and two trachytes; the rest are devitrified rhyolites.

Voids $(4.8 \%)$ - minor amounts of calcite filling voids in groundmass.

Tlr-11. G1-4805 Slightly to partly welded, zeolitized, lithic-rich, ash-flow tuff

Shards - sir.ilar to those in G1-4612, but some shard centers are filled with clays, others with calcite. Less albite is present than in G1-4200.

Groundmass - same as in G1-4700.

Pumice - similar to those in G1-4700; first appearance of sericite.

Phenocrysts $(13 \%)$ - plagioclase, sanidine, quartz, and biotite. Altera-

tion of plagioclase phenocrysts is more thorough than it was in previous samples. Some plagioclase cores are replaced by calcite.

Accessory minerals - apatite, allanite, and zircon.

Oxides - same as in G1-4612.

Lithics (19\%) - lithic fragments range from dacite to rhyolite. The abundance of spherulite fragments is greatly increased. First appearance of fragments of low-grade metamorphic rocks [low-grade pelite with white mica (?)].

Fillings - calcite selectively replaces some shards, pumice, and phenocrysts on a wide scale. Chlorite also occurs in some phenocrysts. Voids (none hit during point count).

Tlr-12. G1-4875 Slightly welded, zeolitized, lithic-rich, ash-flow tuff Shards - clear, undeformed, and up to $200 \mu \mathrm{m}$ across. Shard edges are infilled by a rim of small analcime crystals (5 to $10 \mu \mathrm{m})$. Shard centers are filled by aibite, calcite, or epoxy. Groundmass - light tan to brown, with equant (5- to 10- $\mu \mathrm{m})$ grains of analcime, albite, disseminated clays, and oxides ( $\mathrm{Fe}$ and $\mathrm{Mn}$ ). 
Pumice - up to $5 \mathrm{~mm}$ across, slightly deformed, with small analcime crystals filling tubes, and clays lining tube walls. These pumices contain a high percentage of clays, imparting a brown color. Many open vug regions are filled by calcite. Once again, a small percentage of clays is altered to chlorite, and analcime has partially altered albite. Sericite grains are oriented and abundant.

Phenocrysts (8.6\%) - sanidine, plagioclase, quartz, and biotite. Some feldspar cores are wormy, some edges ragged, and overgrowths are sometimes seen. Feldspars often occur in clots with biotite.

Accessory minerals - zircon, allanite, and apatite.

Oxides $-C_{6}$ in matrix, $c_{3}$ near calcite vein.

Lithics (11\%) - there are scarce dacite fragments. One dacite(?) has all feldspar completely altered. Most fragments are devitrified rhyolites, the majority of which are just large spherulite fragments. Voids $(0.3 \%)$.

Veins - there rre two major vein fillings, calcite and analcime. Calcite is a later-stage filling. Calcite is pervasive as a late-stage filling of shards, pumice, and phenocryst cores. Some chlorite occurs as random masses in the groundmass.

Tlr-13. Gl-4912 Slightly welded, zeolitized, lithic-rich, ash-flow tuff

Shards - same as in G1-4875.

Groundmass - similar to G1-4876, but with higher albite content.

Pumice - similar to those in G1-4876, but with slightly higher clay content. Terminated albite crystals occur in pumice voids.

Phenocrysts (7\%) - sanidine, plagioclase, quartz, and biotite.

Accessory minerals - apatite and zircon.

Lithics (10\%) - lithic fragments are similar to those in Gl-4876; however, some devitrified rhyolites consist of secondary spherulites with an outer rim of opal(?).

Voids (none hit during point count) - calcite and chlorite fill some small groundmass voids (as in $\mathrm{Gl}-4875$ ); slightly more abundant. 
(Tta) Unnamed older tuffs, Unit A

Tta-1. G1-4998 Nonwelded, argillized, ash-flow tuff

Shards - up to $300 \mu \mathrm{m}$ long, dark brown, and altered to minor clays. Shards have central analcime and albite fillings. It is difficult to determine shard proportions due to clouding by clays, although clays often line the shard boundaries.

Groundmass - a clear mix of analcime and albite with very little clay or oxides. Chlorite is rare, and there is very little calcite.

Pumice - up to $4 \mathrm{~mm}$ long, dark brown due to disseminated clays. Major phases within the pumices are albite laths, sericite, analcime, and clays. Albite is radiotaxially oriented. Pumices were heavily fractured during eruption and/or thin sectioning. Fractures are filled by analcime and/or epoxy.

Phenocrysts (21\%) - quartz, plagioclase, sanidine, and biotite.

Accessory minerals - allanite, apatite, and zircon.

Lithics (4.2\%) - fragments include many devitrified rhyolites.

Voids $(4.8 \%)$.

Tta-2. G1-5026 Slightly welded, albitized, ash-flow tuff

Shards - up to $600 \mu \mathrm{m}$ long, clear, with indistinct borders and a high percentage of void space. Shards are moctly altered to albite with minor analcime. Stringers of equant (5- to 10- $\mathrm{m}$ ) crystals of albite line the shard rims. Albite crystals growing into the central voids reach $200 \times 25 \mu \mathrm{m}$. The lack of sharp outline for the shards is due to albite encroachment from the groundmass.

Groundmass - light tan, a complex mix of 2- to 10- $\mu \mathrm{m}$ interlocking crvstals of analcime, albite, minor clays, and oxides. Clays are partly altered to chlorite, and calcite fills veins and voids.

Pumice - 2 to $4 \mathrm{~mm}$ long, dark brown due to clays in the tube walls. Analcime is still present, but albite is now aligned in two preferred orientations and still very small. Lapilli borders are diffuse due to albitization. Calcite or epoxy fills the central voids.

Phenocrysts (16\%) - sanidine, quartz, plagioclase, and biotite. Some quartz has reacted with analcime to form albite. Therefore, stringers of albite crystals are common around quartz. Feathery 
edges and overgrowths of albite around plagioclase are also common. Most phenocrysts are large, with aitered cores.

Accessory minerals - apatite and zircon.

Oxides $-\mathrm{C}_{5}$.

Lithics (1.8\%) - there are fragments of dacites, devitrified rhyolites, and spherulites. Lithics are much less abundant and smaller than in G1-4998, with some associated chlorite.

Voids (none hit during point count).

Tta-3. G1-5093 slightly welded, albitized ash-flow tuff

Shards - up to $500 \mu \mathrm{m}$, clear, and undeformed. Some 10- to 20- $\mu \mathrm{m}$ analcime grains occur on edges, but these grains are rare. In general, large albite laths $(50 \mu \mathrm{m})$ have grown into and fill the shard centers. A7.so, equant albite, analcime, and minor quartz occur in the shard centers.

Groundmass - brown, with dispersed but abundant oxides. The color comes from clays, but most of that groundmass is analcime with minor equant (5- to 10- $\mu \mathrm{m}$ ) albite crystals scattered about.

Pumice - up to $3 \mathrm{~mm}$ long, tan with black patches. These are very similar to the pumices in G1-5026. Sericite grains are aligned and abundant; albite is less abundant in the pumices but fills all large voids. The lapilli are undeformed and bordered by clays. Looking down the pumice tubes, albite crystals are large and abundant with common oxides. The inner tube portions are filled with calcite.

Phenocrysts (13\%) - quartz, plagioclase, sanidine, and biotite. The core plagioclase phenocrysts are not as altered as they are in G1-5026.

Accessory minerals - apatite, zircon, and allanite.

0xides $-C_{3}-C_{5}$; predominantly $C_{4}$ and very large.

Lithics (2.0\%) - same as in G1-5026.

Voids $(0.2 \%)$.

Tta-4. G1-5126 Partly welded, zeolitized and albitized, ash-flow tuff

Shards - urdeformed, clear, up to $600 \mu \mathrm{m}$ long. Shards are totally filled by analcime. Shard boundaries are encroached by groundmass 
albite and by chlorite. Where shard voids are large, albite crystals have grown into the shard centers.

Groundmass - tan-brown, almost totally replaced by albite with some chlorite. The groundmass is fine grained. Minor analcime and clays also occur. Chlorite in the groundmass replaces some clays. Pumice - large, up to $5 \mathrm{~mm}$ across. Albite (to $20 \mu \mathrm{m}$ ) replaces most of the pumices; chiorite replaces some original clays. Large void regions have terminated albite crystals growing into the centers and are filled by analcime. Oxides are abundant and dispersed. Chlorite borders pumices, while some pumices are preferentially replaced by calcite.

Phenocrysts (24\%) - plagioclase, sanidine, quartz, and biotite. Overgrowths are much larger on plagioclase phenocrysts and some perthitic twinning occurs.

Accessory minerals - allanite, apatite, sphene, and zircon. Oxides - same as in G1-5026.

Lithics (3.5\%) - include a few devitrified and spherulitic rhyolite fragments.

Voids (none hit during point count) - calcite fills voids in this section.

Tta-5. G1-5167 Partly welded, zeolitized, lithic-rich, ash-flow tuff

Shards - up to $400 \mu \mathrm{m}$, clear, and undeformed. Alteration ranges from pure analcime to pure albite. Types seen are:

1. pure massive analcime,

2. albite stringers surrounding analcime core,

3. granular, interlocking albite, and

4. albite laths filling vugs, with analcime in the interstitial regions.

Groundmass - tan-brown, with I- to 10-um grains, mostly of albite (60\%) with analcime (30\%), clays, chlorite, and oxides (10\%).

Pumice - Most are undeformed, with analcime in tubes, clays on walls, and minor albite. A few pumices are similar to the shards of G1-5126 (i.e., recrystallized to albite and sericite, but with no large albite laths). Chlorite replaces some clays. 
Phenocrysts (18\%) - sanidine, plagioclase, quartz, biotite, and hornblende.

Accessory minerals - sphene, allanite, apatite, and zircon. oxides $-\mathrm{C}_{2}-\mathrm{C}_{4}$.

Lithics (15\%) - consist of rounded spherulitic fragments. Voids $(0.9 \%)$.

Tta-6. G1-5212 Partly welded, zeolitized, ash-flow tuff

Shards - clear, undeformed, and up to $300 \mu \mathrm{m}$ long. Shards are similar to those in G1-5167, except that most are now replaced by massive analcime. There are a minor encroachment by groundmass albite and some instances of albite replacing analcime in the shards.

Groundmass - light tan in color, similar to 61-5167, although the clay content is lower and the albite content is higher. Chlorite is still present in appreciable amounts. Groundmass contains small amounts of calcite.

Pumice - up to $6 \mathrm{~mm}$ long. These pumices commonly have high chlorite contents. Very often, the major portion of the pumice is analcime with disseminated albite crystals nucleating near tube walls. Albite and sericite also occur in the pumices (similar to Gl-5093).

Phenocrysts (22\%) - quartz, sanidine, plagioclase, biotite, and hornblende. Large clots of feldspar phenocrysts occur with very large overgrowths. Many grains are altered.

Accessory minerals - allanite, apatite, zircon, and sphene. Oxides $-\mathrm{C}_{1}-\mathrm{C}_{4}$.

Lithics $(7.5 \%)$ - lithic fragments all consist of spherulites or devitrification products. Half of the fragments are heavily oxidized. Voids (none hit during point count).

\section{Tta-7. G1-5296 Partly welded, zeolitized, ash-flow tuff}

Shards - clear, undeformed, and up to $400 \mu \mathrm{m}$ long. Shard edges are very ragged due to groundmass encroachment. Albite and quartz from the groundmass have grown in from the borders of the shards (5 to $15 \mu \mathrm{m}$ ), but there are all degrees of variation with laths, up to $100 \mu \mathrm{m}$, filling shards with just analcime. Analcime fills the shard centers in all cases. 
Groundmass - tan-brown, with equant grains $(5$ to $10 \mu \mathrm{m})$ of albite, quartz (major), and analcime (minor). Most clays are altered to chlorite or sericite; oxides are fairly rare.

Pumice - typically lighter in color than the groundmass, and up to $15 \mathrm{~mm}$ long. There is a whole progression from analcime and chlorite to albite, sericite, and chlorite. The reaction series is analcima + clay + analcime + clay + minor albite along pumice walls + analcime + clay + major albite and sericite within the pumice + albite + sericite (with albite and minor analcime infilling vugs) $\rightarrow$ oriented albite and sericite in pumice but masking the original fabric. Also, altered clays (sericite \pm chlorite) are often located at the edges or centers of pumices. Calcite commonly fills some portions of the pumices (in one case calcite pervades a pumice).

Phenocrysts $(20 \%) \quad-$ sanidine, quartz, plagioclase, biotite, and hornblende, Phenocrysts are commonly shattered and rehealed. Many feldspar cores are altered.

Accessory minerals - sphene, allanite, apatite, and zircon.

oxides $-C_{1}-C_{2}$.

Lithics (2.7\%) - all lithic fragments are spherulites or devitrified rhyolites.

Voids $(1 \%)$ - calcite fills most voids.

\section{Tta-8. G1-5311 Albitized, bedded tuff}

Shards - not clearly visible. Void regions that slightly mimic shards are filled with albite laths (up to $150 \mathrm{um}$ long) and quartz. The filling sequence is: (1) 5- to 10- $\mu \mathrm{m}$ albite beads lining void, then (2) large laths, finally (3) centers filled with clays or analcime. Groundmass - equant 5- to 20-um grains of albite, quartz, analcime (minor), chlorite, sericite, and disseminated oxides. Calcite is abundant, but does not pervade this sample.

Pumice - dark brown and undeformed. In voids, large albite grains occur parallel to tubes, and albite and sericite are aligned. Clays are partially altered to chlorite. The interstitial regions around albite laths are filled by analcime. The borders of pumices are indistinct due to groundmass enroachment (i.e., severe recrystallization). 
Phenocrysts (14\%) - sanidine, quartz, plagioclase, and biotite.

Accessory minerals - allanite, sphene, apatite, and zircon.

0xides $-C_{1}-C_{4}$, predominantly $C_{1}$.

Lithics (3.8\%) - same as in Gl-5296.

Voids $(0.3 \%)$.

Vein - a very large analcime vein is present.

(Ttb) Unnamed 0lder Tuffs, Unit B

Ttb-1. G1-5348 Albitized, lithic-rich, bedded tuff

Shards - indistinguishable.

Groundmass - dark brown, due to clays and oxides; this is the same as in G1-5311.

Pumice - tan, fine grained, with albite and sericite. There are very few lath-shaped crystals. The lapilli are up to $2 \mathrm{~mm}$ long, with dark borders outlined by $\mathrm{cl}$ ays.

Phenocrysts (17\%) - plagioclase, sanidine, quartz, and biotite.

Accessory minerals - apatite, allanite, sphene, and zircon.

oxides $-C_{1}-C_{7}$; average is $C_{3}$.

Lithics (20\%) - lithic fragments are angular to rounded and consist of devitrified rhyolites. There are also pieces of albitized ash flows. Voids (none hit during point count). Vein - a large calcite-filled vein occurs in this sample.

Ttb-2. G1-5412 Partly welded, zeolitized and albitized, lithic-rich, ash-flow tuff

Shards - clear, $250 \mu \mathrm{m}$, and undeformed. Most shards are replaced by massive analcime. The remainder either have albite and quartz stringers or have minor albite laths growing toward their centers with a central region filled by analcime.

Groundmass - gray-brown, composed primarily of fine-grained albite, analcime, and quartz. Chlorite and sericite are disseminated throughout. There is a high percentage of disseminated $\mathrm{Fe}$ and $\mathrm{Mn}$ oxides.

Pumice - pumices range in color from clear to dark brown, and consist of analcime, minor clays, albite, sericite, and chlorite. The analcime-rich pumices are clear; the albite-rich pumices are dark 
brown. All pumices show gradations between types of alteration. Calcite often fills open void spaces.

Phenocrysts (18\%) - plagioclase, quartz, sanidine, and biotite.

Accessory minerals - allanite, sphene, apatite, and zircon.

0xides $-\mathrm{C}_{1}-\mathrm{C}_{2}$; with chlorite rims.

Lithics (11\%) - lithic fragments consist mostly of devitrified rhyolites and plagioclase-rhyolites.

Voids $(0.2 \%)$ - calcite permeates this section and fills most voids.

Veins - chloritized clays occur in some small veins.

(Ttc) Unnamed older tuffs, Unit C

Itc-1. G1-5498 Slightly to partly welded, zeolitized and albitized, ash-flow tuff

Shards - relatively rare, clear, up to $200 \mu \mathrm{m}$ long. Shards are similar to those in G1-5412, but the shards composed only of analcime predominate.

Groundmass - composed of tan, fine-grained (submicrometer to 5- $\mu \mathrm{m}$ ) albite, quartz, and analcime. Chlorite is very finely disseminated throughout. Oxides occur throughout.

Pumice - a high percentage of this thin section is pumice. Pumices are similar to those in G1-5412, except that a higher percentage is filled by analcime. Often, tube walls have altered to albite and sericite on a fine-grained scale. Is albite- and sericite-altered pumices, the larger vugs commonly have $50-$ to $100-\mu \mathrm{m}$ albite laths.

Phenocrysts (15\%) - plagioclase, sanidine, and biotite. Alteration of feldspars is very pronounced. Altered cores, feathery edges, and perthitic etching are all commonplace.

Accessory minerals - allanite, apatite, zircon, and sphene.

Oxides $-\mathrm{C}_{2}-\mathrm{C}_{7}$; average is $\mathrm{C}_{4}$; phenocrysts are common.

Lithics (6.8\%) - lithic fragments consist of dacite and rhyolite (devitrified, albitized or spherulitic).

Voids $(0.3 \%)$ - calcite fills some voids and veins; the rest are filled by analcime and/or chlorite. 
Ttc-2. G1-5637 Slightly welded, zeolitized, and albitized ash-flow tuff

Shards - shards containing analcime only comprise most of the section;

otherwise the shards are the same as in 61-5412. Shards are clear, and up to $300 \mu \mathrm{m}$ long.

Groundmass - tan, with about equal percentages of analcime, albite, and quartz. The clay content is greater, and sericite is more common. Large chlorite masses occur throughout the sample. Calcite is pervasive; chlorite is less abundant than in shallower samples.

Pumice - pumices are similar to those in 61-5412, except that all have large portions of chlorite (up to $20 \%$ ) and many have been infilled by calcite.

Phenocrysts $(17 \%)$ - plagioclase, sanidine, biotite, and hornblende. Many of the feldspars are totally altered. Some biotites have totally altered to chlorite.

Accessory minerals - apatite, sphene, zircon, and allanite.

oxides $-\mathrm{C}_{1}-\mathrm{C}_{4}$, average is $\mathrm{C}_{2}$.

Lithics $(5.9 \%)$ - there is a wide range of lithic compositions ranging from andesite to rhyolite. All lithic fragments are heavily altered. Voids $(0.1 \%)$.

Ttc-3. G1-5679 Zeolitized and albitized bedded tuff

Shards - similar to G1-5412, although there is a higher percentage of shards containing analcime only. Some shards have recrystallized to optically continuous albite.

Groundmass - similar to G1-5412; however, there is a higher clay content. Pumice - dark brown to black, and up to $6 \mathrm{~mm}$ long. Otherwise they are the same as in G1-5412.

Phenocrysts (21\%) - plagioclase, sanidine, biotite, and hornblende. Accessory minerals - allanite, sphene, apatite, and zircon.

0xides $-C_{1}$ (abundant).

Lithics (5.9\%) - same as in G1-5637.

Filling - calcite and chlorite are present but not abundant. Most filiings are analcime and/or clays. 
Ttc-4. G1-5746 Slightly to partly welded, zeolitized and albitized, ash-flow tuff

Shards - clear, with diffuse borders, and up to $200 \mu \mathrm{m}$ long. Shards that were originally analcime only are altered to albite + quartz with interstitial analcime. No shards have sharp borders; therefore albite and quartz are encroaching from the groundmass. Most shards are partially replaced by albite and quartz. Both end members (analcime, albite + quartz) are relatively rare.

Groundmass - light $\tan$, with equant (1- to $5-\mu m)$ crystals of albite, quartz, and analcime. There are al so dispersed laths (15 to $20 \mu \mathrm{m}$ ) of albite. The rest of the matrix is sericite, oxides, and minor clays. Very little chlorite is present.

Pumice - there is a continuous variation from analcime + clays \pm sericite + albite + sericite. In volume, most of the pumices are analcime + clays. Typically, clays line the borders and form veins through those pumices formed of analcime. As alteration becomes more albite-rich, clays become disseminated throughout the pumices (mottled). Calcite is fairly common within pumices. Large albite laths also grow into some voids.

Phenocrysts (28\%) - plagioclase and biotite.

Accessory minerals - allanite and sphene.

Oxides $-\mathrm{C}_{3}-\mathrm{C}_{6}$. Average is $\mathrm{C}_{4}$ (abundant).

Lithics (6.3\%) - there are numerous fragments of altered dacite and devitrified rhyolite. Chloritization occurs in the lithics.

Voids $(1.4 \%)$.

Veins - calcite is common in veins; analcime fills one vein.

Itc-5. Gl-5847 Slightly to partly welded, albitized, lithic-rich, ash-flow tuff

Shards - undeformed and clear, with diffuse borders. There are large anhedral interlocking grains of albite and quartz ( 10 to $40 \mu \mathrm{m})$ within the shards.

Groundmass - a relatively high concentration of clays in a fine-grained matrix of albite, quartz, sericite, and chlorite. 0xides are also disseminated throughout. Calcite is pervasive. 
Pumice -- up to $4 \mathrm{~mm}$ long, with original textures wiped out by alteration. The pumices are typically rimmed by clays and chlorite. The texture is now an aligned fabric of albite, quartz (?), and micaceous minerals. Albite crystals up to $100 \mu \mathrm{m}$ long occur in the pumice fabric (i.e., the albite is not just a vug filler). Sericite and albite show typical alignment, but these phases are larger than in previous sections. Chlorite is dispersed throughout the pumices, and caicite commoniy fills portions of some pumices.

Phenocrysts (24\%) plagioclase, sanidine, and biotite = Feldspar phenocrysts are partially to totally resorbed. The only components not a?tered are the albite overgrowths and the albite lamellae. The remainder has altered to sericite and albite. Biotites have reacted to chlorite and oxides.

Accessory minerals - apatite, zircon, allanite, and sphene.

oxides $-C_{2}-C_{7}$; the average is $C_{4}$. There are abundant large oxide phenocrysts.

Lithics (20\%) - Compositions range from dacite to rhyolite.

Voids (none hit during point count).

Ttc-6. G1-5947 Slightly to partly welded, zeolitized and albitized ash-flow tuff

Shards - up to $350 \mathrm{\mu m}$, clear, with sharp borders. Shards are undeformed, similar to those in Gl-5412. Most shards are replaced by analcime only.

Groundmass - similar to that in G1-5847; analcime is approximately equal in abundance to albite + quartz.

Pumice - similar to those in 61-5746; analcime is approximately equal to albite + micaceous minerals in abundance, and often both types of alteration reside in the same lapilli.

Phenocrysts (24\%) - plagioclase, sanidine, biotite, and hornblende.

Accessory minerals - apatite, zircon, and perrierite.

oxides $-\mathrm{C}_{1}-\mathrm{C}_{5}$; commonly $\mathrm{C}_{3}$.

Lithics (4.2\%) - consist of dacites and rhyolites.

Voids (none hit during point count). 


\section{CONCLUSIONS}

The thin section descriptions in Sections II through $X$ of this report all fall into one of the categories of devitrified, vitrophyre, vitric, or zeolitized as outlined in the introduction. This fourfold classification is valid for all rocks down through the clinoptilolite-mordenite zone that occurs between the Bullfrog and Tram Members of the Crater Flat tuff in USW G-1 (Section $X$ ). Of the major zeolitizeu intervals (pages 4,5), Zeolite Interval I is most different from the others in that its zeolites are mostly restricted to fillings within fractures, or even within vapor-phase or lithophysal cavities. In Zeolite Intervals II through $V$, regardless of whether clinoptilolite alone or clinoptilolite plus mordenite is present, the grain sizes and textural features remain constant. Micrometer or submicrometer zeolites are common in the groundmass and along the relict walls of shards and pumice fragments, although clinoptilolite crystals of 10 to $50 \mu \mathrm{m}$ line void spaces within these reict pyroclasts. Voids of up to $250 \mu \mathrm{m}$ are abundant throughout those zeolitized intervals. This similarity among Zeolite Intervals II through $V$ supports the geochemical evidence that they behave in a very similar manner regarding sorptive retardation (Daniels et al. 1982). This in turn supports the conclusion that overall retardation at Yucca Mountain can ultimately be modeled on the basis of petrologic subdivisions such as those defined in pages 4 and 5 .

The compositions of clinoptilolites in the zeolitized intervals have been summarized in reports on other drill holes at Yucca Mountain (Caporuscio et a1. 1982; Vaniman et al. 1984). Contrasts between the compositions of the zeolitized intervals are summarized in Fig. 2. Zeolitized Interval I, at the top of the basal vitrophyre in the Topopah Spring Member, has the most Ca-rich clinoptilolite/heulandite compositions. These compositions are similar to Interval I zeolites found on other drill holes at Yucca Mountain (Caporuscio et al. 1982 and Vaniman et al. 1984). The deeper zeolitized intervals in USW G-1 are characterized by alkali-rich clinoptilolites which contain varying amounts of sodium and potassium in exchangeable cation positions. These alkali-rich clinoptilolites generally become more sodic with depth. The observed variations in composition reflect varied sources, origins, or cation-exchange histories within these zeolitized intervals. Further study of these zeolitized intervals is planned in order to better understand the history of zeolitization at Yucca Mountain. An understanding of zeolite 


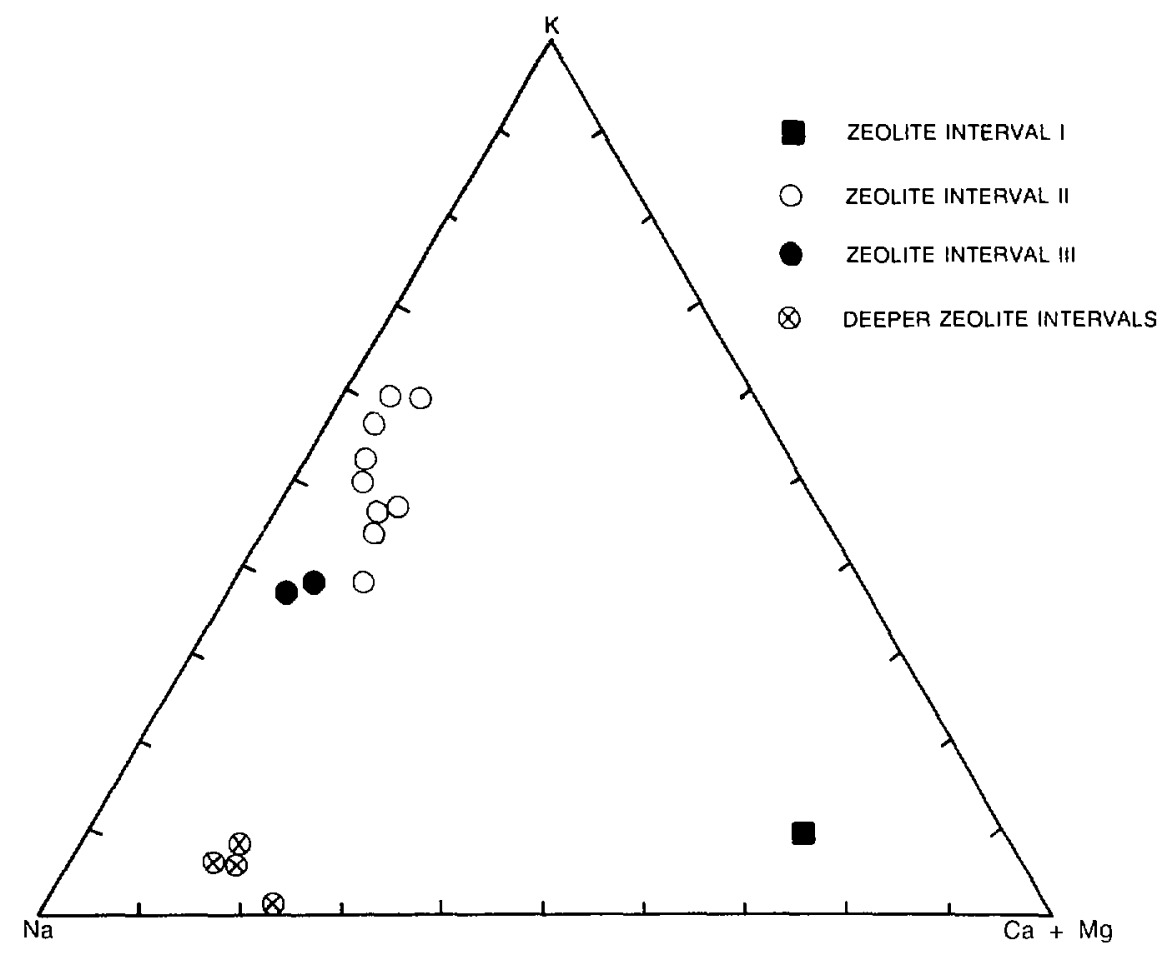

Fig. 2.

Triangular diagram showing exchangeable cation compositions in clinoptilolites from drill hole USW G-1.

origins may also affect the confidence with which the major zeolitized intervals can be projected between and away from the drill holes at Yucca Mountain.

Section $X I$ of this report, describing the deeper petrologic zones below Zeolite Interval IV, includes a great variety of lithologies and mineralogies. It is evident that in these deeper zones, the simpler petrologic classifications are not as useful. Moreover, other mineralogic transitions occur within these deeper rock types. It is here that the abundances of clinoptilolite and mordenite fall off, and the first occurrence of analcime appears. The almost ubiquitous rutile oxidation of the upper zones disappears between 3196- to 3258-ft depth, and the first reduced assemblage of sulfide alteration occurs. It remains to be determined what impact, if any, these deeper zones might have on transport pathways. 


\section{ACKNOWLEDGMENTS}

We thank Roland Hagan who assisted with the microprobe and other laboratory work. David Mann and Tino Lucero prepared excellent thin sections of tuffaceous materials, which are very difficult to section. Barbara Hahn, Diane Griechen and Marcia Jones typed good copy from the scribblings of many authors, and the illustrations were drafted by Janet Repa. Joe Smyth and Jack Purson helped obtain some of the microprobe analyses. We especially thank David Vaniman whose review greatly improved this manuscript.

\section{REFERENCES}

Bence and Albee, "Empirical Correction Factors for Electron Microanalysis of Silicates and Oxides," J. Geol. 76, 382-403 (1968).

Bish, D. L., F. A. Caporuscio, J. F. Copp, B. M. Crowe, J. D. Purson, J. R. Smyth, and R. G. Warren, "Preliminary Stratigraphic and Petrologic Characterization of Core Samples from USW-G1, Yucca Mountain, Nevada,"Los Alamos National Laboratory Report EA-8840-MS (1981).

Bish, D. L., A. E. Ogard, and D. T. Vaniman, "Mineralogy-Petrology and Groundwater Geochemistry of Yucca Mountain Tuffs," Los Alamos National Laboratory Docunent LA-UR-84-332.

Caporuscio, F., D. Vaniman, D. Bish, D. Broxton, B. Arney, G. Heiken, F. Byers, R. Gooley, and E. Semarge, "Petrologic Studies of Drill Cores USW-G2 And UE 25b-1H, Yucca Mountain, Nevada," Los Alamos National Laboratory Report LA-9255-MS (1982).

Carroll, P. I., F. A. Caporuscio, and D. L. Bish, "Further Description of the Petrology of the Topopah Spring Member of the Paintbrush Tuff in Drill Holes UE25a-1 and USW-G1 and of the Lithic-Rich Tuff in USW-G1, Yucca Mountain, Nevada," Los Alamos National Laboratory Report LA-9000-MS (1981).

Daniels, W. R. et al., "Summary Report on the Geochemistry of Yucca Mountain and Environs," Los Alamos National Laboratory Report LA-9328-MS (1982).

Haggerty, S. E., "Oxidation of Opaque Mineral Oxides in Basalts," in Oxide Minerals, Min. Soc. Am. Short Course Notes 3, H6-1 to H6-100 (1976).

Vaniman, D., D. Bish, D. Broxton, F. Byers, G. Heiken, B. Carlos, E. Semarge, F. Caporuscio, and R. Gooley, "Variations in Authigenic Mineralogy and Sorptive Zeolite Abundance at Yucca Mountain, Nevada, Based on Studies of Drill Cores USW GU-3 and G-3," Los Alamos National Laboratory Report LA-9707-MS (1984).

Warren, R. G., F. M. Byers, Jr., and F. A. Caporuscio, "Petrography and Mineral Chemistry of Units of the Topopah Spring, Calico Hills and Crater Flat Tuffs, and 0lder Volcanic Units, with Emphasis on Samples from Drill Hole USW G-1, Yucca Mountain, Nevada Test Site," Los Alamos National Laboratory Report LA-10003-MS (1984). 


\section{APPENDIX}

COMPOSITIONS OF SECONDARY MINERALS IN USW G-I 
Microprobe Analyses of Secondary Minerals in the Topopah Spring Member of the Paintbrush Tuff

\begin{tabular}{|c|c|c|c|}
\hline $\begin{array}{l}\text { Depth } \\
\text { Mineral } \\
\text { Type }\end{array}$ & $\begin{array}{l}1191 \\
\text { VPKF }\end{array}$ & $\begin{array}{l}1240 \\
\text { VPXF }\end{array}$ & $\begin{array}{c}\begin{array}{c}\text { Zeolite } \\
\text { Interval } 1\end{array} \\
1286 \\
\mathrm{Cpt}\end{array}$ \\
\hline $\mathrm{SiO}_{2}$ & 65.98 & 67.18 & 63.46 \\
\hline $\mathrm{Al}_{2} \mathrm{O}_{3}$ & 17.42 & 18.12 & 12.64 \\
\hline Feó & 0.00 & 0.04 & 0.00 \\
\hline $\mathrm{MgO}$ & 0.00 & 0.00 & 0.28 \\
\hline $\mathrm{CaO}$ & 0.17 & 0.23 & 5.09 \\
\hline $\mathrm{BaO}$ & 0.06 & 0.00 & 0.00 \\
\hline $\mathrm{Na}_{2} \mathrm{O}$ & 4.37 & 5.06 & 0.87 \\
\hline$k_{2} 0$ & 10.04 & 9.05 & 0.57 \\
\hline Total & 98.04 & 99.68 & 82.91 \\
\hline
\end{tabular}

Cation Formulas Based on $36(0)$ for Clinoptilolite and $6(0)$ for Feldspars and Glasses

\begin{tabular}{|c|c|c|c|}
\hline si & 3.040 & 3.030 & 14.612 \\
\hline Al. & 0.946 & 0.964 & 3.431 \\
\hline $\mathrm{Fe}$ & 0.000 & 0.002 & 0.000 \\
\hline Mg & 0.000 & 0.000 & 0.096 \\
\hline $\mathrm{Ca}$ & 0.008 & 0.011 & 1.256 \\
\hline Ba & 0.001 & 0.000 & 0.000 \\
\hline $\mathrm{Na}$ & 0.390 & 0.443 & 0.388 \\
\hline K & 0.590 & 0.521 & 0.167 \\
\hline \multicolumn{4}{|c|}{ Coordination of Cations } \\
\hline oct. & 0.990 & 0.976 & 1.908 \\
\hline Total & 4.977 & 4.970 & 19.951 \\
\hline & $\begin{array}{c}0 \text { of } 5 i \\
0.763\end{array}$ & $\begin{array}{c}\text { to } 5 j+A] \\
0.759\end{array}$ & 0.810 \\
\hline
\end{tabular}

Mol.z Potassium, Sodium, and Calcium plus Magnesium

\begin{tabular}{|c|c|c|c|}
\hline$x$ & 59.7 & 53.4 & 8.8 \\
\hline $\mathrm{Na}$ & 39.5 & 45.4 & 20.4 \\
\hline $\mathrm{Ca}+\mathrm{Mg}$ & 0.8 & 1.1 & 70.9 \\
\hline \multicolumn{3}{|c|}{$\begin{array}{l}\text { Uxides Recalculated } t \\
2 \quad 67.30 \quad 67.40\end{array}$} & $\frac{100 \%}{76.54}$ \\
\hline $\mathrm{Al}_{2} \mathrm{U}_{3}$ & 17.77 & 18.18 & 15.25 \\
\hline $\mathrm{FeO}$ & 0.00 & 0.04 & 0.00 \\
\hline $\mathrm{MgO}$ & $0.00^{-}$ & $0.00 \ldots$ & 0.34 \\
\hline $\mathrm{CaO}$ & 0.17 & 0.23 & 6.14 \\
\hline $\mathrm{Ba} 0$ & 0.06 & 0.00 & 0.00 \\
\hline & 4.46 & 5.08 & 1.05 \\
\hline $\mathrm{K}_{2} \mathrm{O}$ & 10.24 & $9.0 \mathrm{~B}$ & 0.69 \\
\hline Tota & 100.00 & 100.00 & 100.00 \\
\hline
\end{tabular}

1 Depth from surface, in feet.

$2 \mathrm{Cpt}=$ clinoptilolite/heulandite; Anle $x$ analcime; AKF = authigenic alkali feldspar; $A A D=$ authigenic albite; VPKF = vapor phase sanidine; VPAD $=$ vapor phase albite; $D K F=$ devitrification sanidine; $5 m=$ smectite; $G l=$ glass. 
Zeolite Interval II

\begin{tabular}{|c|c|c|c|c|c|c|}
\hline $\begin{array}{l}\text { Depthd } \\
\text { Mineral } \\
\text { Type }\end{array}$ & $\begin{array}{l}1436 \\
\text { Cpt }\end{array}$ & $\begin{array}{l}1561 \\
\text { Cpt }\end{array}$ & $\begin{array}{l}1561 \\
\text { Cpt }\end{array}$ & $\begin{array}{l}1561 \\
\text { Cpt }\end{array}$ & $\begin{array}{l}1639 \\
\text { Cpt }\end{array}$ & $\begin{array}{l}1774 \\
\text { Cpt }\end{array}$ \\
\hline $\mathrm{SiO}_{2}$ & 68.93 & 65.68 & 69.54 & 63.38 & 66.54 & 68.08 \\
\hline $\mathrm{A}_{2} \mathrm{O}_{3}$ & 12.41 & 11.59 & 11.84 & 10.90 & 11.54 & 12.17 \\
\hline feo & 0.00 & 0.02 & 0.18 & 0.00 & 0.00 & 0.00 \\
\hline $\mathrm{MgO}$ & 0.00 & 0.00 & 0.00 & 0.00 & 0.02 & 0.09 \\
\hline CaO & 0.88 & 0.62 & 0.56 & $0.5 i$ & 0.73 & 1.11 \\
\hline$B .0$ & 0.00 & 0.00 & C. 00 & 0.00 & 0.09 & 0.03 \\
\hline $\mathrm{Ha}_{2} \mathrm{O}$ & 2.29 & 2.60 & 2.30 & 2.29 & 2.59 & 2.84 \\
\hline$K_{2} 0$ & 5.89 & 4.87 & 5,64 & 4.99 & 4.56 & 4.20 \\
\hline Total & 90.40 & 85.38 & 90.06 & 82.13 & 86.07 & 88.52 \\
\hline
\end{tabular}

Cation Formulas 8ased on 36(0) for Clinoptilolite

$\begin{array}{lrrrrrr}\text { Si } & 14.884 & 14.950 & 15.027 & 15.006 & 14.995 & 14.904 \\ \text { A } 1 & 3.159 & 3.110 & 3.016 & 3.043 & 3.066 & 3.141 \\ \text { Fe } & 0.000 & 0.004 & 0.033 & 0.000 & 0.000 & 0.000 \\ \text { Hg } & 0.000 & 0.000 & 0.000 & 0.000 & 0.007 & 0.029 \\ \text { Ca } & 0.204 & 0.151 & 0.130 & 0.145 & 0.176 & 0.260 \\ \text { Ba } & 0.000 & 0.000 & 0.000 & 0.000 & 0.008 & 0.003 \\ \text { Ha } & 0.959 & 1.147 & 0.964 & 1.051 & 1.132 & 1.205 \\ \text { K } & 1.623 & 1.414 & 1.555 & 1.507 & 1.311 & 1.173\end{array}$

Coordination of Cations

Tet. $\quad \begin{array}{llllll}18.043 & 18.060 & 18.043 & 18.049 & 18.060 & 18.045\end{array}$

$\begin{array}{llllllll}\text { Oct. } & 2.785 & 2.717 & 2.681 & 2.703 & 2.634 & 2.671\end{array}$

Total $\quad 20.828 \quad 20.776 \quad 20.724 \quad 20.752 \quad 20.694 \quad 20.715$

Ratio of Si to $S i+A\}$

$$
\begin{array}{llllll}
0.825 & 0.828 & 0.833 & 0.831 & 0.830 & 0.826
\end{array}
$$

Mol.x Potassium, Sodfum, and Calcium plus Magnesium

$\begin{array}{lrrrrrr}K & 58.3 & 52.1 & 58.7 & 55.8 & 49.9 & 44.0 \\ \text { No } & 34.4 & 42.3 & 36.4 & 38.9 & 43.1 & 45.2 \\ \text { Ca+Hig } & 7.3 & 5.6 & 4.9 & 5.3 & 7.0 & 10.9\end{array}$

Uxides Recalculated to 1005

$\begin{array}{lrrrrrr}\mathrm{SIO}_{2} & 76.25 & 76.93 & 77.22 & 77.17 & 77.31 & 76.91 \\ \mathrm{~A}_{2} \mathrm{O}_{3} & 13.73 & 13.57 & 13.15 & 13.27 & 13.41 & 13.75 \\ \mathrm{FeO} & 0.00 & 0.02 & 0.20 & 0.00 & 0.00 & 0.00 \\ \mathrm{MgO} & 0.00 & 0.00 & 0.00 & 0.00 & 0.02 & 0.10 \\ \mathrm{CaO} & 0.97 & 0.73 & 0.62 & 0.69 & 0.85 & 1.25 \\ \mathrm{BaO} & 0.00 & 0.00 & 0.00 & 0.00 & 0.10 & 0.03 \\ \mathrm{Ma}_{2} \mathrm{O} & 2.53 & 3.05 & 2.55 & 2.79 & 3.01 & 3.21 \\ \mathrm{~K}_{2} \mathrm{O} & 6.52 & 5.70 & 6.26 & 6.08 & 5.30 & 4.74 \\ \text { Totel } & 100.00 & 100.00 & 100.00 & 100.00 & 100.00 & 100.00\end{array}$

1 Depth from surface, in feet.

2 CPt = clinopt tiolite/heulandite; Anic - analctere; AKF = outhigenic alkalf feldspar; $M_{b}$ - authigenic albite; YPKF - vepor phtse sanidine; VPAD - vapor phase albite; DKF - devitrification sonfdine; 5 - satectite; 61 - glass. 


\section{Microprobe Analyses of Secondary Minerais in the Prow Pass Member}

\begin{tabular}{|c|c|c|c|c|c|c|c|c|c|c|c|}
\hline \multirow[b]{2}{*}{$\begin{array}{l}\text { Depthl } \\
\text { Mineral } \\
\text { Type }^{2}\end{array}$} & \multicolumn{3}{|c|}{ Zeolite Interval II } & \multicolumn{6}{|c|}{ Central Prow Pass Devitrified Zone } & \multicolumn{2}{|c|}{ Zeolite Interval 111} \\
\hline & $\begin{array}{l}1819 \\
\text { Cpt }\end{array}$ & $\begin{array}{l}1819 \\
\text { Cpt }\end{array}$ & $\begin{array}{l}1854 \\
C p t\end{array}$ & $\begin{array}{l}1982 \\
\text { VPKF }\end{array}$ & $\begin{array}{l}1982 \\
\text { YPKF }\end{array}$ & $\begin{array}{l}1982 \\
\text { VPKF }\end{array}$ & $\begin{array}{l}1982 \\
\text { VPKF }\end{array}$ & $\begin{array}{l}1982 \\
\text { VPKF }\end{array}$ & $\begin{array}{l}1982 \\
\text { VPKF }\end{array}$ & $\begin{array}{r}20 \mathrm{~B} 3 \\
\mathrm{Cpt}\end{array}$ & $\begin{array}{r}2166 \\
\text { Cpt }\end{array}$ \\
\hline $\mathrm{Siv}_{2}$ & 68.18 & 66.41 & 68.00 & 65.71 & 66.42 & 66.26 & 66.12 & 66.29 & 66.18 & 67.32 & 68.94 \\
\hline $\mathrm{Al}_{2} \mathrm{O}_{3}$ & 11.75 & 11.30 & 12.73 & 17.70 & 17.91 & 17.90 & 17.77 & 17.49 & 17.77 & 11.71 & 12.66 \\
\hline $\mathrm{FeO}$ & 0.00 & 0.37 & 0.00 & 0.00 & 0.00 & 0.02 & 0.00 & 0.00 & 0.00 & 0.00 & 0.23 \\
\hline Myo & 0.07 & 0.09 & 0.09 & 0.00 & 0.00 & 0.00 & 0.00 & 0.00 & 0.00 & 0.07 & 0.09 \\
\hline $\mathrm{CaO}$ & 1.07 & 1.14 & 1.16 & 0.13 & 0.17 & 0.21 & 0.11 & 0.15 & 0.15 & 0.78 & 0.71 \\
\hline 820 & 0.00 & 0.08 & 0.00 & 0.05 & 0.00 & 0.02 & 0.00 & 0.17 & 0.02 & 0.08 & 0.08 \\
\hline $\mathrm{Na}_{2} \mathrm{O}$ & 2.63 & 2.68 & 2.32 & 2.06 & 2.43 & 2.82 & 2.21 & 2.12 & 2.54 & 3.13 & 3.84 \\
\hline$k_{2}{ }_{0}$ & 3.86 & 3.02 & 4.09 & 12.76 & 12.20 & 11.77 & 12.48 & 12.20 & 12.36 & 3.34 & 3.77 \\
\hline Total & 87.56 & 85.09 & 88.39 & 98.41 & 99.13 & 98.90 & 98.69 & 98.42 & 99.02 & 86.43 & 90.32 \\
\hline
\end{tabular}

Cation Formulas Based on $36(U)$ for Clinoptilolite and $8(0)$ for Feldspars

$\begin{array}{lrrrrrrrrrrr}\text { Si } & 15.021 & 15.034 & 14.859 & 3.038 & 3.039 & 3.038 & 3.042 & 3.05 \text { b } & 3.036 & 15.008 & 14.816 \\ \text { Al } & 3.052 & 3.016 & 3.280 & 0.965 & 0.966 & 0.962 & 0.964 & 0.950 & 0.962 & 3.078 & 3.208 \\ \text { Fe } & 0.000 & 0.070 & 0.000 & 0.000 & 0.000 & 0.001 & 0.000 & 0.000 & 0.000 & 0.000 & 0.041 \\ \text { Mg } & 0.023 & 0.030 & 0.029 & 0.000 & 0.000 & 0.000 & 0.000 & 0.000 & 0.000 & 0.023 & 0.029 \\ \text { Ca } & 0.253 & 0.277 & 0.272 & 0.006 & 0.008 & 0.010 & 0.005 & 0.007 & 0.007 & 0.186 & 0.163 \\ \text { Ba } & 0.000 & 0.007 & 0.000 & 0.001 & 0.000 & 0.000 & 0.000 & 0.003 & 0.000 & 0.007 & 0.007 \\ \text { Na } & 1.123 & 1.176 & 0.983 & 0.185 & 0.216 & 0.251 & 0.197 & 0.189 & 0.226 & 1.353 & 1.600 \\ \text { K } & 1.085 & 0.872 & 1.140 & 0.753 & 0.712 & 0.688 & 0.733 & 0.717 & 0.724 & 0.950 & 1.034\end{array}$

Coordination of Cations

$\begin{array}{lrrrrrrrrrrr}\text { Tet. } & 18.073 & 18.050 & 18.139 & 4.003 & 4.005 & 4.000 & 4.006 & 4.006 & 3.999 & 18.086 & 18.023 \\ \text { Oct. } & 2.484 & 2.433 & 2.424 & 0.945 & 0.936 & 0.951 & 0.935 & 0.917 & 0.958 & 2.519 & 2.874 \\ \text { Total } & 20.557 & 20.483 & 20.563 & 4.948 & 4.942 & 4.951 & 4.941 & 4.923 & 4.957 & 20.605 & 20.898\end{array}$

Ratio of Si to $\mathrm{Si}+\mathrm{AL}$
$0.831 \quad 0.833$
$0.819 \quad 0.759$
0.759
0.759
0.759
$0.763 \quad 0.760$
$0.830 \quad 0.822$

Mol.z Potassium, Sodiun, and Calcium plus Magnesium

$\begin{array}{lrrrrrrrrrrr}K & 43.7 & 37.0 & 47.0 & 79.8 & 76.1 & 72.5 & 78.3 & 78.5 & 75.6 & 37.8 & 36.6 \\ \text { Na } & 45.2 & 49.9 & 40.5 & 19.6 & 23.0 & 26.4 & 21.1 & 20.7 & 23.6 & 53.8 & 56.6 \\ \text { Ca+Mg } & 11.1 & 13.0 & 12.4 & 0.7 & 0.9 & 1.1 & 0.6 & 0.8 & 0.8 & 8.3 & 6.8\end{array}$

Oxides Recalculated to $100 \mathrm{x}$

$\begin{array}{lrrrrrrrrrrr}\mathrm{SiO}_{2} & 77.87 & 78.05 & 76.93 & 66.77 & 67.00 & 67.00 & 67.00 & 67.35 & 66.83 & 77.89 & 76.33 \\ \mathrm{Al}_{2} \mathrm{O}_{3} & 13.42 & 13.28 & 14.40 & 17.99 & 18.07 & 18.00 & 18.01 & 17.77 & 17.95 & 13.55 & 14.02 \\ \mathrm{FeO} & 0.00 & 0.43 & 0.00 & 0.00 & 0.00 & 0.02 & 0.00 & 0.00 & 0.00 & 0.00 & 0.25 \\ \mathrm{MyO} & 0.08 & 0.11 & 0.10 & 0.00 & 0.00 & 0.00 & 0.00 & 0.00 & 0.00 & 0.08 & 0.10 \\ \mathrm{CaO} & 1.22 & 1.34 & 1.31 & 0.13 & 0.17 & 0.21 & 0.11 & 0.15 & 0.15 & 0.90 & 0.79 \\ \mathrm{BaO} & 0.00 & 0.09 & 0.00 & 0.05 & 0.00 & 0.02 & 0.00 & 0.17 & 0.02 & 0.09 & 0.09 \\ \mathrm{Na}_{2} \mathrm{O} & 3.00 & 3.15 & 2.62 & 2.09 & 2.45 & 2.85 & 2.24 & 2.15 & 2.57 & 3.62 & 4.25 \\ \mathrm{~K}_{2} \mathrm{O} & 4.41 & 3.55 & 4.63 & 12.97 & 12.31 & 11.90 & 12.65 & 12.40 & 12.48 & 3.86 & 4.17 \\ \mathrm{Total} & 100.00 & 100.00 & 100.00 & 100.00 & 100.00 & 100.00 & 100.00 & 100.00 & 100.00 & 100.00 & 100.00\end{array}$

\footnotetext{
1 Depth from surface, in feet.

$2 \mathrm{CPt}=\mathrm{clinoptilolite/heulandite;} \mathrm{Anic}=$ analcime; AKF = authigenic alkali feldspar; MAb = authigenic albite; YPKF = vapor phase sanidine; VPAD = vapor phase dibite; OKF = devitrification sanidine; Sin $=$ smectite; GI = glass.
} 
Microprobe Analyses of Secondary Minerais in the Tram Member of the Crater Flat Tuff

\begin{tabular}{|c|c|c|c|c|c|c|c|c|c|c|c|c|c|c|}
\hline $\begin{array}{l}\text { Depthl } \\
\text { Hinerd } \\
\text { Type? }\end{array}$ & $\begin{array}{l}2790 \\
\text { VPKF }\end{array}$ & $\begin{array}{l}2790 \\
\text { YPKF }\end{array}$ & $\begin{array}{l}2901 \\
\text { VPKF }\end{array}$ & $\begin{array}{l}3371 \\
\text { Anlc }\end{array}$ & $\begin{array}{l}3371 \\
\text { Anlc }\end{array}$ & $\begin{array}{l}3371 \\
\text { AnIC }\end{array}$ & $\begin{array}{l}3371 \\
\text { Anlc }\end{array}$ & $\begin{array}{l}3371 \\
\text { Anlc }\end{array}$ & $\begin{array}{l}3371 \\
\text { Anic }\end{array}$ & $\begin{array}{l}3371 \\
\text { Anlc }\end{array}$ & $\begin{array}{l}3371 \\
\text { Anlc }\end{array}$ & $\begin{array}{l}3371 \\
\text { Anlc }\end{array}$ & $\begin{array}{l}3371 \\
\text { Anlc }\end{array}$ & $\begin{array}{l}3371 \\
\text { Anle }\end{array}$ \\
\hline $\mathrm{SiO}_{2}$ & 66.55 & 67.34 & 67.02 & 59.07 & 58.66 & 59.61 & 58.95 & 59.08 & 58.94 & 58.91 & 57.92 & 59.05 & 58.96 & 58.09 \\
\hline $\mathrm{Al}_{2} \mathrm{O}_{3}$ & 17.64 & 17.84 & 18.33 & 19.57 & 19.61 & 19.50 & 19.63 & 19.72 & 19.71 & 19.43 & 19.49 & 19.58 & 19.60 & 19.14 \\
\hline $\mathrm{Fe} 0$ & 0.08 & 0.04 & 0.06 & 0.00 & 0.00 & 0.00 & 0.00 & 0.00 & 0.00 & 0.00 & 0.00 & 0.00 & 0.00 & 0.00 \\
\hline $\mathrm{MgO}$ & 0.00 & 0.00 & No & ND & ND & No & ND & ND & ND & ND & ND & ND & ND & ND \\
\hline $\operatorname{Cav}$ & 0.21 & 0.18 & 0.14 & 0.02 & 0.00 & 0.00 & 0.01 & 0.04 & 0.01 & 0.00 & 0.01 & 0.00 & 0.02 & 0.00 \\
\hline Bau & 0.00 & 0.00 & 0.50 & 0.00 & 0.00 & 0.00 & 0.00 & 0.00 & 0.00 & 0.00 & 0.00 & 0.00 & 0.00 & 0.00 \\
\hline $\mathrm{Na}_{2} \mathrm{O}$ & 1.54 & 1.69 & 2.69 & 11.97 & 11.93 & 12.03 & 12.09 & 12.05 & 11.79 & 12.09 & 11.95 & 12.06 & 12.23 & 11.65 \\
\hline$k_{2} \mathrm{O}$ & 12.43 & 12.74 & 12.27 & 0.00 & 0.00 & 0.00 & 0.00 & 0.00 & 0.00 & 0.00 & 0.00 & 0.00 & 0.00 & 0.00 \\
\hline Total & 98.45 & 99.83 & 101.01 & 90.62 & 90.20 & 91.14 & 90.68 & 90.89 & 90.45 & 90.43 & 89.37 & 90.69 & 90.81 & 88.88 \\
\hline
\end{tabular}

Cation Formulas Based on $36(0)$ for Clinoptilolite. $7(0)$ for Analcime, and $8(0)$ for Feldspars

\begin{tabular}{|c|c|c|c|c|c|c|c|c|c|c|c|c|c|c|}
\hline Si & 3.060 & 3.057 & 3.024 & 2.516 & 2.510 & 2.523 & 2.511 & 2.510 & 2.513 & 2.516 & 2.504 & 2.514 & 2.610 & 2.621 \\
\hline Al & 0.956 & 0.955 & 0.975 & 0.983 & 0.989 & 0.973 & 0.986 & 0.988 & 0.991 & 0.978 & 0.993 & 0.983 & 0.984 & 0.979 \\
\hline $\mathrm{Fe}$ & 0.003 & 0.002 & 0.002 & 0.000 & 0.000 & 0.000 & 0.000 & 0.000 & 0.000 & 0.000 & 0.000 & 0.000 & 0.000 & 0.000 \\
\hline $\mathrm{Mg}$ & 0.000 & 0.000 & ND & MO & ND & NO & ND & ND & ND & ND & MD & ND & ND & ND \\
\hline $\mathrm{Ca}$ & 0.010 & 0.009 & 0.007 & 0.000 & 0.000 & 0.000 & 0.000 & 0.002 & 0.000 & 0.000 & 0.000 & 0.000 & 0.001 & 0.000 \\
\hline $\mathrm{Ba}$ & 0.000 & 0.000 & 0.009 & 0.000 & 0.000 & 0.000 & 0.000 & 0.000 & 0.000 & 0.000 & 0.000 & 0.000 & 0.000 & 0.000 \\
\hline $\mathrm{Na}$ & 0.137 & 0.149 & 0.235 & 0.988 & 0.990 & 0.987 & 0.998 & 0.993 & 0.975 & 1.001 & 1.002 & 0.996 & 1.009 & 0.980 \\
\hline K & 0.729 & 0.738 & 0.706 & 0.000 & 0.000 & 0.000 & 0.000 & 0.000 & 0.000 & 0.000 & 0.000 & 0.000 & 0.000 & 0.000 \\
\hline
\end{tabular}

Coordination of Cations

\begin{tabular}{|c|c|c|c|c|c|c|c|c|c|c|c|c|c|c|}
\hline t. & 4.016 & 4.012 & 3.999 & 3.498 & 3.500 & 3.496 & 3.497 & 3.498 & 3.504 & 3.494 & 3.498 & 3.497 & 3.493 & 3.500 \\
\hline & 0.880 & 0.897 & 0.960 & 0.989 & 0.990 & 0.987 & 0.999 & 0.994 & 0.575 & 1.001 & 1.002 & 0.996 & 1.010 & 980 \\
\hline & 896 & 4.909 & 959 & .487 & 490 & 4.484 & .496 & 4.492 & 1.479 & .496 & .500 & 92 & 3 & \\
\hline
\end{tabular}

Ratio of Si to Si+Al

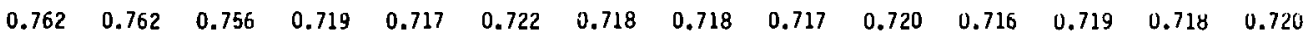

Mol .x Potassium, Sodium, and Calcium plus Magnesium

\begin{tabular}{|c|c|c|c|c|c|c|c|c|c|c|c|c|c|c|}
\hline$k$ & 83.2 & 82.4 & 74.5 & 0.0 & 0.0 & 0.0 & 0.0 & 0.0 & 0.0 & 0.0 & 0.0 & 0.0 & 0.0 & 0.0 \\
\hline $\mathrm{Na}$ & $1 b .7$ & 16.6 & 24.8 & 100.0 & 100.0 & 100.0 & 100.0 & 99.8 & 100.0 & 100.0 & 100.0 & 100.0 & 99.9 & U \\
\hline $\mathrm{Ca}+\mathrm{Mg}$ & 1.2 & 1.0 & 0.7 & 0.0 & 0.0 & 0.0 & 0.0 & 0.2 & 0.0 & 0.0 & 0.0 & 0.0 & 0.1 & \\
\hline
\end{tabular}

Oxides Recalculated to $100 \%$

\begin{tabular}{|c|c|c|c|c|c|c|c|c|c|c|c|c|c|c|}
\hline $\mathrm{SiO}_{2}$ & 67.60 & 67.45 & 66.35 & 65.18 & 65.03 & 65.40 & 65.01 & 65.00 & 65.16 & 65.14 & 64.81 & 65.11 & 64.93 & 65.36 \\
\hline $\mathrm{Al}_{2} \mathrm{O}_{3}$ & 17.92 & 17.87 & 18.15 & 21.60 & 21.74 & 21.40 & 21.65 & 21.70 & 21.79 & 21.49 & 21.81 & 21.59 & 21.58 & 21.53 \\
\hline $\mathrm{FeO}$ & 0.08 & 0.04 & 0.06 & 0.00 & 0.00 & 0.00 & 0.00 & 0.00 & 0.00 & 0.00 & 0.00 & 0.00 & 0.00 & 0.00 \\
\hline $\mathrm{Mgu}$ & 0.00 & 0.00 & ND & MD & MD & MD & HO & KD & ND & ND & ND & ND & ND & ND \\
\hline $\mathrm{CaO}$ & 0.21 & 0.18 & 0.14 & 0.01 & 0.00 & 0.00 & 0.01 & 0.04 & 0.01 & 0.00 & 0.01 & 0.00 & 0.02 & 0.00 \\
\hline $\mathrm{BaO}$ & 0.00 & 0.00 & 0.50 & 0.00 & 0.00 & 0.00 & 0.00 & 0.00 & 0.00 & 0.00 & 0.00 & 0.00 & 0.00 & 0.04 \\
\hline $\mathrm{Na}_{2}{ }_{2}$ & 1.56 & 1.69 & 2.66 & 13.21 & 13.23 & 13.20 & 13.33 & 13.26 & 13.03 & 13.37 & 13.37 & 13.30 & 13.47 & 13.11 \\
\hline$k_{2}{ }^{0}$ & 12.63 & 12.76 & 12.15 & 0.00 & 0.00 & 0.00 & 0.00 & 0.00 & 0.00 & 0.00 & 0.00 & 0.00 & 0.00 & 0.00 \\
\hline Total & 100.00 & 100.00 & 100.00 & 100.00 & 200.00 & 100.00 & 100.00 & 100.00 & 100.00 & 100.00 & 100.00 & 100.00 & 100.00 & 100.00 \\
\hline
\end{tabular}

1 Depth from surface, in feet.

2 Cpt = clinoptilolite/neulandite; Anlc = analcime; AKF = authigenic alkali feldspar; AAb = authigenic albite; VPKF = vapor phase Sanidine; YPAD - vapor phase albite; DKF = devitrification sanidine; Sm - smectite; Gi = glass. 
Microprobe Analyses of Secondary Minerals in the Dacite Lava

\begin{tabular}{|c|c|c|c|c|c|c|c|c|c|c|c|c|c|}
\hline $\begin{array}{l}\text { Depth } \\
\text { Mineral } \\
\text { Type? }\end{array}$ & $\begin{array}{l}3598 \\
\text { Cpt }\end{array}$ & & $\begin{array}{r}3598 \\
\text { Cpt }\end{array}$ & $\begin{array}{c}3658 \\
\mathrm{Sm}\end{array}$ & $\begin{array}{c}3658 \\
\text { Sin }\end{array}$ & 3706 & $\begin{array}{r}3706 \\
\text { Cpt }\end{array}$ & $\begin{array}{l}3850 \\
5 \mathrm{~m}\end{array}$ & $\begin{array}{c}3850 \\
5 m\end{array}$ & $\begin{array}{c}3850 \\
\mathrm{sm}\end{array}$ & $\begin{array}{c}3850 \\
\mathrm{Sm}\end{array}$ & $\begin{array}{l}3850 \\
S_{m}\end{array}$ & $\begin{array}{l}3850 \\
S_{m}\end{array}$ \\
\hline $\mathrm{SiV}_{2}$ & 66.20 & 63.00 & 64.30 & 55.90 & 55.20 & 56.10 & 69.60 & 61.10 & 58.40 & 56.70 & 57.80 & 55.70 & 56.70 \\
\hline $\mathrm{TiU}_{2}$ & 0.00 & 0.08 & 0.19 & 0.40 & 0.34 & 0.35 & 0.00 & 0.35 & 0.37 & 0.40 & 0.61 & 0.50 & 0.38 \\
\hline $\mathrm{Al}_{2} \mathrm{O}_{3}$ & 12.50 & 12.70 & 12.50 & 15.50 & 14.90 & 13.30 & 10.70 & 13.80 & 15.50 & 14.80 & 13.80 & 13.10 & 13.80 \\
\hline Feu & 0.76 & 0.44 & 0.91 & 5.80 & 6.90 & 9.20 & 0.06 & 7.20 & 7.20 & 7.70 & 7.20 & 9.10 & 7.90 \\
\hline $\mathrm{MgO}$ & 0.00 & 0.04 & 0.12 & 3.65 & 3.51 & 4.50 & 0.00 & 2.42 & 3.06 & 2.90 & 2.29 & 3.51 & 3.54 \\
\hline Cav & 1.56 & 1.59 & 1.51 & 0.84 & 0.96 & 0.98 & 1.90 & 0.73 & 0.71 & 0.68 & 0.45 & 0.70 & 0.75 \\
\hline $\mathrm{BaO}$ & 1.12 & 0.98 & 0.86 & 0.00 & 0.05 & 0.08 & 0.14 & 0.02 & 0.05 & 0.00 & 0.00 & 0.00 & 0.00 \\
\hline $\mathrm{Na}_{2} \mathrm{U}$ & 4.25 & 4.75 & 4.57 & $0.2 B$ & 0.36 & $0.5 b$ & 3.50 & 1.47 & 1.68 & 1.57 & 1.48 & 1.31 & 1.69 \\
\hline $\mathrm{K}_{2} \mathrm{~J}$ & 0.69 & 0.67 & 0.53 & 1.04 & 1.58 & 2.87 & 0.07 & 1.14 & 1.30 & 1.26 & 1.47 & 2.24 & 1.73 \\
\hline Tota & 87.08 & 84.15 & 85.49 & 83.41 & 83.80 & 87.93 & 45.97 & 88.23 & 88.27 & 86.01 & $8 b .10$ & 86.16 & 86.49 \\
\hline
\end{tabular}

Cation Formulas 8ased on 36(0) for Clinoptilolite and $24(0)$ for Clays

\begin{tabular}{|c|c|c|c|c|c|c|c|c|c|c|c|c|c|}
\hline Si & 14.728 & 14.533 & 14.590 & 8.830 & 8.793 & 8.738 & 15.306 & 9.182 & 8.838 & 8.837 & 9.054 & 8,817 & 8.848 \\
\hline Ti & ND & 0.014 & 0.032 & 0.048 & 0.041 & 0.041 & 0.000 & 0.040 & 0.042 & 0.047 & 0.072 & 0.060 & 0.045 \\
\hline AI & 3.279 & 3.454 & 3.344 & 2.887 & 2.798 & 2.442 & 2.774 & 2.445 & 2.766 & 2.720 & 2.549 & 2.445 & 2.539 \\
\hline Fe & 0.141 & 0.085 & 0.173 & 0.766 & 0.919 & 1.198 & 0.011 & 0.905 & 0.911 & 1.004 & 0.943 & 1.205 & 1.031 \\
\hline $\mathrm{Mg}$ & 0.000 & 0.014 & 0.041 & 0.859 & 0.833 & 1.045 & 0.000 & 0.542 & 0.690 & 0.674 & 0.535 & 0.828 & 0.823 \\
\hline $\mathrm{Ca}$ & 0.372 & 0.393 & 0.367 & 0.142 & 0.164 & 0.164 & 0.448 & 0.118 & 0.115 & 0.114 & 0.076 & 0.119 & 0.125 \\
\hline $\mathrm{Ba}$ & 0.098 & 0.089 & 0.076 & 0.000 & 0.003 & 0.005 & 0.012 & 0.001 & 0.003 & 0.000 & 0.000 & 0.000 & 0.000 \\
\hline $\mathrm{Na}$ & 1.833 & 2.125 & 2.011 & 0.086 & 0.111 & 0.166 & 1.492 & 0.428 & 0.493 & 0.474 & 0.450 & 0.402 & 0.511 \\
\hline$k$ & 0.196 & 0.168 & 0.153 & 0.210 & 0.321 & 0.570 & 0.020 & 0.219 & 0.251 & 0.251 & 0.294 & $0.4 b 2$ & 0.344 \\
\hline
\end{tabular}

Coordination of Cations

Tet. $\quad \begin{array}{lllllllllllll}18.007 & 17.987 & 17.934 & 11.717 & 11.591 & 11.180 & 28.080 & 11.627 & 11.604 & 11.556 & 11.603 & 11.262 & 11.386\end{array}$

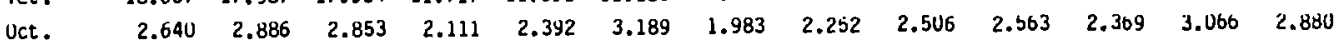
$\begin{array}{llllllllllllll}\text { Total } & 20.647 & 20.873 & 20.788 & 13.827 & 13.984 & 14.369 & 20.063 & 13.879 & 14.109 & 14.119 & 13.971 & 14.328 & 14.266\end{array}$

Ratio of Si to Si+Ai
$0.818 \quad 0.808$
$0.814 \quad 0.754$
0.759
0.782
0.847
0.790
$0.762 \quad 0.765$
0.780
$0.783 \quad 0.777$

Mol.z Potassium, Sodium, and Calcium plus Magnesium

\begin{tabular}{|c|c|c|c|c|c|c|c|c|c|c|c|c|c|}
\hline$K$ & 8.2 & 6.2 & 6.0 & 16.2 & 22.5 & 29.3 & 1.0 & 16.7 & 16.2 & 16.6 & 21.7 & 25.1 & 19.1 \\
\hline $\mathrm{Na}$ & 76.4 & 78.7 & 78.2 & 6.6 & 7.8 & 8.5 & 76.2 & 32.8 & 31.8 & 33.4 & 33.2 & 22.3 & 28.3 \\
\hline $\mathrm{Ca}+\mathrm{Mg}$ & 15.5 & 15.1 & 15.9 & 77.2 & 69.8 & 62.1 & 22.8 & 50.5 & 52.0 & 52.1 & 45.1 & 52.6 & 32.6 \\
\hline
\end{tabular}

Oxides Recalculated to $100 \%$

\begin{tabular}{|c|c|c|c|c|c|c|c|c|c|c|c|c|c|}
\hline $\mathrm{SiO}_{2}$ & 76.02 & 74.87 & 75.21 & 67.02 & 65.87 & 63.80 & 80.96 & 69.25 & 66.16 & 65.92 & 67.92 & 64.65 & 65.56 \\
\hline $\mathrm{TiU}_{2}$ & NO & 0.10 & 0.22 & 0.48 & 0.41 & 0.40 & 0.00 & 0.40 & 0.42 & 0.47 & 0.72 & 0.58 & 0.44 \\
\hline $\mathrm{Al}_{2} \mathrm{U}_{3}$ & 14.35 & 15.09 & 14.62 & 18.58 & 17.78 & 15.13 & 12.45 & 15.64 & 17.56 & 17.21 & 16.22 & 15.20 & 15.96 \\
\hline $\mathrm{FeO}$ & 0.87 & 0.52 & 1.06 & 6.95 & 8.23 & 10.46 & 0.07 & 8.16 & 8.16 & 8.95 & 8.46 & 10.96 & 9.13 \\
\hline MyO & 0.00 & 0.05 & 0.14 & 4.38 & 4.19 & 5.12 & 0.00 & 2.74 & 3.47 & 3.37 & 2.69 & 4.07 & 4.09 \\
\hline $\mathrm{CaO}$ & 1.79 & 1.89 & 1.77 & 1.01 & 1.15 & 1.11 & 2.21 & 0.83 & 0.80 & 0.79 & 0.53 & 0.81 & 0.87 \\
\hline Sav & 1.29 & 1.16 & 1.01 & 0.00 & 0.06 & 0.09 & 0.16 & 0.02 & 0.06 & 0.00 & 0.00 & 0.00 & 0.00 \\
\hline $\mathrm{Na}_{2} \mathrm{U}$ & 4.88 & 5.64 & 5.35 & 0.34 & 0.43 & 0.63 & 4.07 & 1.67 & 1.90 & 1.83 & 1.74 & 1.52 & 1.95 \\
\hline $2^{0}$ & 0.79 & 0.58 & 0.62 & 1.25 & 1.89 & 3.26 & 0.08 & 1.29 & 1.47 & 1.46 & 1.73 & 2.60 & 2.00 \\
\hline Tota & 100.00 & 100.00 & 100.00 & 100.00 & 100.00 & $\mathrm{i} 00.00$ & 100.00 & 100.00 & 100.00 & 100.00 & 100.00 & 100.00 & 100.00 \\
\hline
\end{tabular}

Depth from surface, in feet.

2 Cpt $=$ clinoptilolite/heulandite; Anic = analcime; AKF = authigentc alkalf feldspar; Mb = authigenic albite; UPKF = vapor phase sanidine; VPAD = vapor phase albite; OKF = devitrification sanidine; Sa = smectite; Gl $=$ glass. 


\section{Microprobe Analyses of Secondary Minerals in the Lithic-Rich Tuff}

\begin{tabular}{|c|c|c|c|c|c|c|c|c|c|c|c|c|c|}
\hline $\begin{array}{l}\text { Depthd } \\
\text { Mineral } \\
\text { Type? }\end{array}$ & $\begin{array}{l}4095 \\
\text { Anle }\end{array}$ & $\begin{array}{l}4095 \\
\text { Anle }\end{array}$ & $\begin{array}{l}4095 \\
\text { Anle }\end{array}$ & $\begin{array}{l}4095 \\
\text { Anle }\end{array}$ & $\begin{array}{l}4208 \\
\text { AKF }\end{array}$ & $\begin{array}{c}4208 \\
\sin \end{array}$ & $\begin{array}{l}4208 \\
\text { Anic }\end{array}$ & $\begin{array}{l}4208 \\
\text { Anle }\end{array}$ & $\begin{array}{l}4208 \\
\text { Anic }\end{array}$ & $\begin{array}{l}4208 \\
\text { Anle }\end{array}$ & $\begin{array}{l}4295 \\
\text { Anls }\end{array}$ & $\begin{array}{l}4295 \\
\text { Anle }\end{array}$ & $\begin{array}{l}4 ? 95 \\
\text { Anls }\end{array}$ \\
\hline $\mathrm{SiO}_{2}$ & 60.00 & 60.00 & 59.90 & 60.20 & 66.90 & 56.70 & 58.20 & 57.00 & 58.40 & 57.20 & 60.20 & 59.40 & 59.40 \\
\hline $\mathrm{THO}_{2}$ & 0.00 & 0.03 & 0.00 & 0.00 & 0.00 & 0.38 & 0.00 & 0.00 & 0.00 & 0.00 & 0.00 & 0.00 & 0.00 \\
\hline $\mathrm{Al}_{2} \mathrm{O}_{3}$ & 18.50 & 18.40 & 17.80 & 18.20 & 16.30 & 13.80 & 19.50 & 20.00 & 19.20 & 19.30 & 18.90 & 19.50 & 19.30 \\
\hline$F=0$ & 0.11 & 0.06 & 0.04 & 0.04 & 0.00 & 7.90 & 0.00 & 0.00 & 0.00 & 0.00 & 0.07 & 0.04 & 0.07 \\
\hline $\mathrm{MgO}$ & 0.02 & 0.00 & 0.01 & 0.00 & 0.00 & 3.54 & 0.00 & 0.00 & 0.00 & 0.00 & 0.00 & 0.00 & 0.00 \\
\hline $\mathrm{CaO}$ & 0.00 & 0.04 & 0.03 & 0.00 & 0.00 & 0.75 & 0.00 & 0.00 & 0.00 & 0.00 & 0.03 & 0.02 & 0.00 \\
\hline $\mathrm{BaO}$ & 0.25 & 0.00 & 0.25 & 0.00 & 0.00 & 0.00 & 0.00 & 0.00 & 0.00 & 0.00 & 0.03 & 0.00 & 0.00 \\
\hline $\mathrm{Na}_{2} \mathrm{O}$ & 12.00 & 11.60 & 11.20 & 11.40 & 0.04 & 1.69 & 12.10 & 12.50 & 12.20 & 12.10 & 11.30 & 11.50 & 11.50 \\
\hline $\mathrm{K}_{2} \mathrm{O}$ & 0.00 & 0.02 & 0.00 & 0.00 & 15.00 & 1.73 & 0.00 & 0.00 & 0.00 & 0.00 & 0.00 & 0.00 & 0.00 \\
\hline Total & 90.88 & 90.15 & 89.23 & 89.84 & 98.24 & 86.49 & 89.80 & 89.50 & 89.80 & 88.60 & 90.53 & 90.46 & 90.27 \\
\hline
\end{tabular}

Cation Formulas Dased on $24(0)$ for Clay5, $7(0)$ for Analcime, and $8(0)$ for Felospars

$\begin{array}{llllllllllllll}\text { S1 } & 2.552 & 2.562 & 2.583 & 2.575 & 3.107 & 8.848 & 2.505 & 2.471 & 2.514 & 2.498 & 2.556 & 2.528 & 2.533 \\ \text { Ti } & 0.000 & 0.001 & 0.000 & 0.000 & 0.000 & 0.045 & 0.000 & 0.000 & 0.000 & 0.000 & 0.000 & 0.000 & 0.000 \\ \text { Al } & 0.928 & 0.926 & 0.905 & 0.918 & 0.893 & 2.539 & 0.990 & 1.022 & 0.975 & 0.994 & 0.946 & 0.978 & 0.970 \\ \text { Fe } & 0.004 & 0.002 & 0.001 & 0.001 & 0.000 & 1.031 & 0.000 & 0.000 & 0.000 & 0.000 & 0.002 & 0.001 & 0.002 \\ \text { Mg } & 0.001 & 0.000 & 0.001 & 0.000 & 0.000 & 0.823 & 0.000 & 0.000 & 0.000 & 0.000 & 0.000 & 0.000 & 0.000 \\ \text { Ca } & 0.000 & 0.002 & 0.001 & 0.000 & 0.000 & 0.125 & 0.000 & 0.000 & 0.000 & 0.000 & 0.001 & 0.001 & 0.000 \\ \text { Ba } & 0.004 & 0.000 & 0.004 & 0.000 & 0.000 & 0.000 & 0.000 & 0.000 & 0.000 & 0.000 & 0.000 & 0.000 & 0.000 \\ \mathrm{Na} & 0.990 & 0.960 & 0.937 & 0.945 & 0.004 & 0.511 & 1.010 & 1.051 & 1.018 & 1.025 & 0.930 & 0.949 & 0.951 \\ \mathrm{~K} & 0.000 & 0.001 & 0.000 & 0.000 & 0.907 & 0.889 & 0.344 & 0.000 & 0.000 & 0.000 & 0.000 & 0.000 & 0.000\end{array}$

Cooraination of Cations

\begin{tabular}{|c|c|c|c|c|c|c|c|c|c|c|c|c|c|}
\hline et. & 3.480 & 3.488 & 3.488 & 3.492 & 4.000 & 11.386 & 3.495 & 3.493 & 3.489 & 3.492 & 3.502 & 3.506 & .504 \\
\hline Ort & 9 & 0.966 & 0.944 & 0.947 & 0.892 & 2.880 & 1.010 & 1.051 & 1.018 & 1.025 & 0.935 & 0.951 & 953 \\
\hline & 79 & .455 & .433 & 4.439 & 4.893 & 14.266 & 4.505 & 4.544 & 4.508 & 4.517 & 4.436 & 1.457 & 457 \\
\hline
\end{tabular}

Ratio of Si to $\$ i+A$

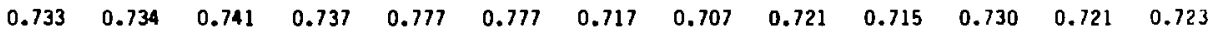

Mol. 1 Potassium, Sodiun, and Calcium plus Magnesium

\begin{tabular}{|c|c|c|c|c|c|c|c|c|c|c|c|c|c|}
\hline K & 0.0 & 0.1 & 0.0 & 0.0 & 99.6 & 19.1 & 0.0 & 0.0 & 0.0 & 0.0 & 0.0 & 0.0 & 0.0 \\
\hline $\mathrm{Ma}$ & 99.9 & 99.7 & 99.8 & 100.0 & 0.4 & 28.3 & 100.0 & 100.0 & 100.0 & 100.0 & 99.9 & 99.9 & 100.0 \\
\hline$a+M g$ & 0.1 & 0.2 & 0.2 & 0.0 & 0.0 & 52.6 & 0.0 & 0.0 & 0.0 & 0.0 & 0.1 & 0.1 & 0.0 \\
\hline
\end{tabular}

Oxides Recalculated to $100 x$

\begin{tabular}{|c|c|c|c|c|c|c|c|c|c|c|c|c|c|}
\hline $\mathrm{i}_{2}$ & 6.02 & 56.56 & 67.13 & 7.01 & 68.10 & 65.56 & 64.81 & 63.69 & 65.03 & 64.56 & 66.50 & 65.66 & 55.80 \\
\hline${ }_{2}$ & 0.00 & 0.03 & .00 & 0.00 & 0.00 & 0.44 & .00 & .00 & 0.00 & 0.00 & 0.00 & 0.00 & 0.00 \\
\hline 0 & 20.36 & 0.41 & 19.95 & 20.26 & 16.59 & 15.96 & 1.71 & 22.35 & 1.38 & 1.78 & 20.88 & 21.56 & 21.38 \\
\hline 0 & 0.12 & 07 & 0.04 & .04 & .00 & .13 & 00 & 00 & .00 & .00 & .08 & .04 & .08 \\
\hline & 02 & .00 & 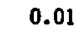 & 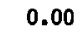 & 0.00 & 4.09 & & 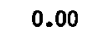 & .00 & 10 & 00 & 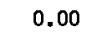 & 0.00 \\
\hline & 0.00 & 0.04 & .03 & .00 & 0.00 & 0.87 & .00 & 0.00 & 0.00 & 0.00 & .03 & .02 & 0.00 \\
\hline & 0.28 & 0.00 & .28 & 0.00 & 0.00 & 0.00 & 0.00 & 0.00 & 0.00 & 0.00 & .03 & .00 & 0.00 \\
\hline 2 & 13.20 & 12.87 & 12.5 & 12.69 & 0.04 & 1.95 & 13.47 & 13.97 & 13.59 & 13.66 & 12.48 & 12.71 & 12.74 \\
\hline & 0 & 0 & .0 & .00 & .27 & 2.00 & 0.00 & 0.00 & 0.00 & 0.00 & 0.00 & 0.00 & 0.00 \\
\hline & 00.00 & 00.00 & 00.00 & 10.00 & 00.00 & 100.00 & 00.00 & 00.00 & 100.00 & 00.00 & 100.00 & 100.00 & 100.00 \\
\hline
\end{tabular}

1 Depth from surface, in feet.
2 CDt - Clinoptilolite/heulandite; Anlc - analcime; AKF - authigenic alkali felospar; Mb = authigenic albite; YPKF = vapor phase sanidine; YPAb = vapor phase albite; OKF = devterification sanidine; Sa * smectite; Gl = glass. 
Microprobe Analyses of Secondary Minerals in the Lithic-Rich Tuff (cont)

\begin{tabular}{|c|c|c|c|c|c|c|c|c|c|c|c|c|c|c|c|}
\hline$\underset{\substack{\text { Depth! } \\
\text { inneral } \\
\text { Type? }}}{ }$ & $\begin{array}{l}4341 \\
\text { Anle }\end{array}$ & $\begin{array}{l}4341 \\
\text { Anic }\end{array}$ & $\begin{array}{l}4341 \\
\text { Anle }\end{array}$ & $\begin{array}{l}4341 \\
\text { Anlc }\end{array}$ & $\begin{array}{l}4341 \\
\text { Anle }\end{array}$ & $\begin{array}{r}4341 \\
a 4 b\end{array}$ & $\begin{array}{l}4341 \\
M b\end{array}$ & $\begin{array}{l}4400 \\
M b\end{array}$ & $\begin{array}{r}4400 \\
M b\end{array}$ & $\begin{array}{l}4400 \\
\text { Anle }\end{array}$ & $\begin{array}{l}4400 \\
\text { Anlc }\end{array}$ & $\begin{array}{l}4400 \\
\text { Anlc }\end{array}$ & $\begin{array}{l}4400 \\
\text { Anlc }\end{array}$ & $\begin{array}{l}4400 \\
\text { Anlc }\end{array}$ & $\begin{array}{l}4400 \\
\text { Anle }\end{array}$ \\
\hline $\mathrm{SiO}_{2}$ & 59.60 & 59.10 & 60.40 & 57.20 & 58.80 & 67.80 & 69.10 & 69.30 & 69.40 & 60.20 & 59.90 & 61.20 & 61.60 & 61.10 & 60.00 \\
\hline $\mathrm{THO}_{2}^{2}$ & 0.03 & 0.00 & 0.00 & 0.01 & 0.00 & 0.02 & 0.05 & no & ND & mo & $\mathrm{mo}$ & Mo & พ & WD & nO \\
\hline $\mathrm{Al}_{2} \mathrm{O}_{3}$ & 19.40 & 18.40 & 18.50 & 20.00 & 18.60 & 19.60 & 19.10 & 19.00 & 19.80 & 20.20 & 19.80 & 19.90 & 19.10 & 19.50 & 19.00 \\
\hline Fé & 0.00 & 0.00 & 0.00 & 0.00 & 0.00 & 0.00 & 0.01 & 0.00 & 0.02 & 0.00 & 0.00 & 0.04 & 0.00 & 0.00 & 0.00 \\
\hline $\mathrm{MgD}$ & 0.01 & 0.03 & 0.02 & 0.02 & 0.04 & 0.01 & 0.02 & 0.00 & 0.00 & 0.00 & 0.00 & 0.00 & 0.00 & 0.00 & 0.00 \\
\hline $\mathrm{CAO}$ & 0.01 & 0.01 & 0.02 & 0.06 & 0.01 & 0.16 & 0.15 & 0.00 & 0.14 & 0.02 & 0.00 & 0.00 & 0.00 & 0.20 & 0.00 \\
\hline B.0 & 0.07 & 0.05 & 0.11 & 0.07 & 0.00 & 0.00 & 0.15 & 0.00 & 0.13 & 0.00 & 0.00 & 0.00 & 0.26 & 0.00 & 0.07 \\
\hline $\mathrm{Ha}_{2} \mathrm{O}$ & 11.80 & 11.40 & 11.60 & 12.50 & 11.50 & 11.80 & 11.80 & 11.10 & 11.60 & 11.80 & 11.60 & 11.60 & 11.60 & 11.20 & 11.40 \\
\hline$k_{2}{ }^{2}$ & 0.00 & 0.00 & 0.01 & 0.00 & 0.00 & 0.01 & 0.13 & 0.58 & 0.05 & 0.00 & 0.00 & 0.00 & 0.00 & 0.00 & 0.00 \\
\hline Total & 90.92 & 88.99 & 90.66 & 89.86 & 88.95 & 99.40 & 100.51 & 99.98 & 101.14 & 92.22 & 91.30 & 92.74 & 92.56 & 92.00 & 90.47 \\
\hline
\end{tabular}

Cation Formulas based on $7(0)$ for Analcie and $8(0)$ for Feldspars

\begin{tabular}{|c|c|c|c|c|c|c|c|c|c|c|c|c|c|c|c|}
\hline St & 2.528 & 2.556 & 2.565 & 2.471 & 2.545 & 2.981 & 3.007 & 3.024 & 2.996 & 2.515 & 2.525 & 2.537 & 2.562 & 2.550 & 2.550 \\
\hline$T_{1}$ & 0.001 & 0.000 & 0.000 & 0.000 & 0.000 & 0.001 & 0.002 & NO & mo & ND & MD & ND & ND & NO & HD \\
\hline AI & 0.970 & 0.938 & 0.926 & 1.019 & 0.949 & 1.016 & 0.980 & $0.97 B$ & $1.00 \mathrm{~B}$ & 0.995 & 0.984 & 0.973 & 0.936 & 0.959 & 0.952 \\
\hline Fe & 0.000 & 0.000 & 0.000 & 0.000 & 0.000 & 0.000 & 0.000 & 0.000 & 0.001 & 0.000 & 0.000 & 0.001 & 0.000 & 0.000 & 0.000 \\
\hline Mg & 0.001 & 0.002 & 0.001 & 0.001 & 0.003 & 0.001 & 0.001 & 0.000 & 0.000 & 0.000 & 0.000 & 0.000 & 0.000 & 0.000 & 0.000 \\
\hline co & 0.000 & 0.000 & 0.001 & 0.003 & 0.000 & 0.008 & 0.007 & 0.000 & 0.006 & 0.001 & 0.000 & 0.000 & 0.000 & 0.009 & 0.000 \\
\hline 8. & 0.001 & 0.001 & 0.002 & 0.001 & 0.000 & 0.000 & 0.003 & 0.000 & 0.002 & 0.000 & 0.000 & 0.000 & 0.004 & 0.000 & 0.001 \\
\hline هו & 0.970 & 0.956 & 0.955 & 1.047 & 0.965 & 1.006 & 0.996 & 0.939 & 0.971 & 0.956 & 0.948 & 0.932 & 0.935 & 0.906 & 0.940 \\
\hline & .000 & 0.000 & .001 & 0.000 & 0.000 & 0.001 & 0.007 & 0.032 & 0.003 & 0.000 & 0.000 & 0.000 & 0.000 & 0.000 & 0.000 \\
\hline
\end{tabular}

Coordination of Cotions

$\begin{array}{llllllllllllllll}\text { Tet. } & 3.498 & 3.494 & 3.491 & 3.490 & 3.495 & 3.998 & 3.987 & 4.002 & 4.004 & 3.509 & 3.509 & 3.509 & 3.498 & 3.509 & 3.503\end{array}$

$\begin{array}{llllllllllllllll}\text { oct. } & 0.974 & 0.959 & 0.960 & 1.053 & 0.968 & 1.016 & 1.016 & 0.971 & 0.983 & 0.957 & 0.948 & 0.934 & 0.940 & 0.915 & 0.941\end{array}$

$\begin{array}{llllllllllllllll}\text { Total } & 4.471 & 4.453 & 4.450 & 4.543 & 4.463 & 5.013 & 5.003 & 4.973 & 4.987 & 4.466 & 4.457 & 4.443 & 4.438 & 4.424 & 4.443\end{array}$

Rat to of 51 to $S T+A 1$

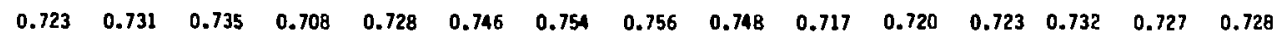

Mol.z Potassium, Socium, and Calctum plus Magnesium

\begin{tabular}{|c|c|c|c|c|c|c|c|c|c|c|c|c|c|c|c|}
\hline  & 0.0 & 0.0 & 0.1 & 0.0 & 0.0 & 0.1 & 0.7 & 3.3 & 0.3 & 0.0 & 0.0 & 0.0 & 0.0 & 0.0 & 0.0 \\
\hline da & 99.9 & 99.7 & 99.7 & 99.6 & 99.7 & 99.1 & 98.5 & 96.7 & 99.1 & 99.9 & 100.0 & 100.0 & 100.0 & 99.0 & 100.0 \\
\hline $\mathrm{l}+\mathrm{kg}$ & 0.1 & 0.3 & 0.2 & 0.4 & 0.3 & 0.8 & 0.8 & 0.0 & 0.7 & 0.1 & 0.0 & 0.0 & 0.0 & 1.0 & 0.0 \\
\hline
\end{tabular}

Oxides Recelculated to 1008

\begin{tabular}{|c|c|c|c|c|c|c|c|c|c|c|c|c|c|c|c|}
\hline $\mathrm{SH}_{2}$ & 65.55 & 66.41 & 66.62 & 63.65 & 66.10 & 68.21 & 68.75 & 69.31 & 68.62 & 65.28 & 65.61 & 65.99 & 66.55 & 66.41 & 66.32 \\
\hline $\mathrm{THO}_{2}$ & 0.03 & $\begin{array}{r}0.00 \\
20.68\end{array}$ & 0.00 & 0.01 & 0.00 & 0.02 & 0.05 & mo & $m$ & $m$ & No & 10 & mo & 10 & HD \\
\hline $\begin{array}{l}\mathrm{Al}_{2} \mathrm{O}_{3} \\
\mathrm{FeO}\end{array}$ & $\begin{array}{r}21.34 \\
0.00\end{array}$ & $\begin{array}{r}20.68 \\
0.00\end{array}$ & $\begin{array}{r}20.41 \\
0.00\end{array}$ & $\begin{array}{r}22.26 \\
0.00\end{array}$ & $\begin{array}{r}20.91 \\
0.00\end{array}$ & $\begin{array}{r}19.72 \\
0.00\end{array}$ & $\begin{array}{r}19.00 \\
0.01\end{array}$ & $\begin{array}{r}19.00 \\
0.00\end{array}$ & $\begin{array}{r}19.58 \\
0.02\end{array}$ & $\begin{array}{r}21.90 \\
0.00\end{array}$ & $\begin{array}{r}21.69 \\
0.00\end{array}$ & $\begin{array}{r}21.46 \\
0.04\end{array}$ & $\begin{array}{r}20.64 \\
0.00\end{array}$ & $\begin{array}{r}21.20 \\
0.00\end{array}$ & $\begin{array}{r}21.00 \\
0.00\end{array}$ \\
\hline Mgo 0 & 0.01 & 0.03 & 0.02 & 0.02 & 0.04 & 0.01 & 0.02 & 0.00 & 0.00 & 0.00 & 0.00 & 0.00 & 0.00 & 0.00 & 0.00 \\
\hline C०O & 0.01 & 0.01 & 0.02 & 0.07 & 0.01 & 0.16 & 0.15 & 0.00 & 0.14 & 0.02 & 0.00 & 0.00 & 0.00 & 0.22 & 0.00 \\
\hline 840 & 0.08 & 0.06 & 0.12 & 0.08 & 0.00 & 0.00 & 0.15 & 0.00 & 0.13 & 0.00 & 0.00 & 0.00 & 0.28 & 0.00 & 0.08 \\
\hline $\mathrm{m}_{2}{ }^{3}$ & 12.98 & 12.61 & 12.80 & 13.91 & 12.93 & 11.87 & 11.74 & 11.10 & 11.47 & 12.80 & 12.71 & 12.51 & 12.53 & 12.17 & 12.60 \\
\hline$k_{2} \overline{0}$ & 0.00 & 0.00 & 0.01 & 0.00 & 0.00 & 0.01 & 0.13 & 0.58 & 0.05 & 0.00 & 0.00 & 0.00 & 0.00 & 0.00 & 0.00 \\
\hline Total & 100.00 & 100.00 & 100.00 & 100.00 & 100.00 & 100.00 & 100.00 & 100.00 & 100.00 & 100.00 & 100.00 & 100.00 & 100.00 & 100.00 & 100.00 \\
\hline
\end{tabular}




\section{Microprobe Analyses of Secondary Minerals in the Lithic-Rich Tuff (cont)}

\begin{tabular}{|c|c|c|c|c|c|c|c|c|c|c|c|c|c|c|}
\hline $\begin{array}{l}\text { Depthl } \\
\text { Mineral } \\
\text { Type } 2\end{array}$ & $\begin{array}{l}4503 \\
\text { Anlc }\end{array}$ & $\begin{array}{l}4503 \\
\text { Anlc }\end{array}$ & $\begin{array}{l}4503 \\
\text { Anic }\end{array}$ & $\begin{array}{l}4503 \\
\text { AKF }\end{array}$ & $\begin{array}{l}4503 \\
\text { UPKF }\end{array}$ & $\begin{array}{l}4503 \\
\text { VPKF }\end{array}$ & $\begin{array}{l}4612 \\
\text { Anic }\end{array}$ & $\begin{array}{l}4612 \\
\text { An!c }\end{array}$ & $\begin{array}{l}4612 \\
\text { Anlc }\end{array}$ & $\begin{array}{l}4700 \\
\text { Anlc }\end{array}$ & $\begin{array}{r}4700 \\
\text { Anlc } \\
\end{array}$ & $\begin{array}{l}4700 \\
\text { Anlc }\end{array}$ & $\begin{array}{l}4700 \\
\text { Anlc }\end{array}$ & $\begin{array}{l}4876 \\
\text { Anlc }\end{array}$ \\
\hline $\mathrm{SiO}_{2}$ & 59.00 & 59.80 & 57.50 & 67.30 & 65.90 & 63.90 & 60.50 & 59.70 & 61.00 & 56.80 & 57.80 & 58.40 & 58.20 & 59.10 \\
\hline $\mathrm{TiO}_{2}$ & 0.00 & 0.00 & 0.00 & 0.02 & 0.08 & 0.12 & 0.00 & 0.00 & 0.00 & ND & MD & MD & MD & 0.05 \\
\hline $\mathrm{Al}_{2} \mathrm{O}_{3}$ & 18.60 & 18.60 & 19.80 & 16.40 & 18.10 & 18.30 & 18.90 & 18.80 & 18.60 & 20.20 & 19.70 & 19.70 & 20.00 & 18.90 \\
\hline $\mathrm{Fe} 0$ & 0.00 & 0.00 & 0.00 & 0.01 & 0.11 & 0.12 & 0.07 & 0.05 & 0.03 & 0.05 & 0.04 & 0.01 & 0.04 & 0.00 \\
\hline $\mathrm{MgO}$ & 0.00 & 0.00 & 0.00 & 0.02 & 0.00 & 0.01 & 0.02 & 0.02 & 0.04 & 0.00 & 0.00 & 0.00 & 0.00 & 0.02 \\
\hline Cav & 0.04 & 0.02 & 0.02 & 0.04 & 0.25 & 0.25 & 0.02 & 0.02 & 0.02 & 0.00 & 0.00 & 0.00 & 0.00 & 0.00 \\
\hline $\mathrm{BaO}$ & 0.02 & 0.00 & 0.00 & 0.05 & 0.85 & 0.97 & 0.00 & 0.09 & 0.00 & 0.03 & 0.05 & 0,18 & 0.00 & 0.00 \\
\hline $\mathrm{Na}_{2} \mathrm{O}$ & 11.70 & 11.60 & 12.20 & 0.07 & 4.65 & 5.47 & 11.90 & 12.20 & 12.00 & 11.80 & 11.90 & 11.80 & 11.80 & 11.60 \\
\hline$k_{2} u$ & 0.00 & 0.01 & 0.04 & 25.20 & 9.77 & $8.5 b$ & 0.01 & 0.00 & 0.00 & 0.00 & 0.00 & 0.00 & 0.00 & 0.00 \\
\hline Total & 89.36 & 90.03 & 89.56 & 99.11 & 99.71 & 97.69 & 91.22 & 90.88 & 91.69 & 88.88 & 89.49 & 90.09 & 90.04 & 89.87 \\
\hline
\end{tabular}

Cation Formulas Based on $7(0)$ for Analcime and $8(0)$ for feldspars

\begin{tabular}{|c|c|c|c|c|c|c|c|c|c|c|c|c|c|c|}
\hline si & 2.545 & 2.556 & 2.486 & 3.103 & 3.006 & 2.974 & 2.548 & 2.539 & 2.563 & 2.472 & 2.497 & 2.506 & 2.496 & $2.53 \mathrm{~b}$ \\
\hline $\mathrm{Ti}$ & 0.000 & 0.000 & 0.000 & 0.001 & 0.003 & 0.004 & 0.000 & 0.000 & 0.000 & NO & NO & ND & NO & 0.002 \\
\hline Al & 0.946 & 0.937 & 1.009 & 0.892 & 0.974 & 1.004 & 0.941 & 0.943 & 0.921 & 1.037 & 1.003 & 0.996 & 1.011 & 0.956 \\
\hline $\mathrm{Fe}$ & 0.000 & 0.000 & 0.000 & 0.000 & 0.004 & 0.005 & 0.002 & 0.002 & 0.001 & 0.002 & 0.001 & 0.000 & 0.001 & 0.000 \\
\hline $\mathrm{Mg}$ & 0.000 & 0.000 & 0.000 & 0.001 & 0.000 & 0.001 & 0.001 & 0.001 & 0.003 & 0.000 & 0.000 & 0.000 & 0.000 & 0.001 \\
\hline $\mathrm{Ca}$ & 0.002 & 0.001 & 0.001 & 0.002 & 0.012 & 0.012 & 0.001 & 0.001 & 0.001 & 0.000 & 0.000 & 0.000 & 0.000 & 0.000 \\
\hline $\mathrm{Ba}$ & 0.000 & 0.000 & 0.000 & 0.001 & 0.015 & 0.018 & 0.000 & 0.001 & 0.000 & 0.001 & 0.001 & 0.003 & 0.000 & 0.000 \\
\hline $\mathrm{Na}$ & 0.979 & 0.961 & 1.023 & 0.006 & 0.411 & 0.494 & 0.975 & 1.006 & 0.977 & 0.996 & 0.997 & 0.982 & 0.981 & 0.982 \\
\hline K & 0.000 & 0.001 & 0.002 & 0.894 & 0.569 & 0.508 & 0.001 & 0.000 & 0.000 & 0.000 & 0.000 & 0.000 & 0.000 & 0.000 \\
\hline
\end{tabular}

Coordination of Cations

\begin{tabular}{|c|c|c|c|c|c|c|c|c|c|c|c|c|c|c|}
\hline Tet. & 3.491 & 3.493 & 3.496 & 3.995 & 3.980 & 3.979 & 3.489 & 3.481 & 3.484 & 3.509 & 3.501 & 3.502 & 3.507 & 3.491 \\
\hline Oct. & 0.981 & 0.963 & 1.026 & 0.906 & 1.014 & 1.041 & 0.980 & 1.011 & 0.982 & 0.998 & 0.999 & 0.985 & 0.983 & 0.984 \\
\hline Total & 4.471 & 4.456 & 4.522 & 4.901 & 4.954 & 5.020 & 4.469 & 4.493 & 4,466 & 4.507 & 4.500 & 4.487 & 4.469 & . 476 \\
\hline
\end{tabular}

Ratio of Si to $S i+A$ i

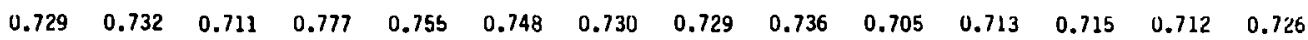

Mol.x Potassium, Sodium, and Calcium plus Magnesium

\begin{tabular}{|c|c|c|c|c|c|c|c|c|c|c|c|c|c|c|}
\hline K & 0.0 & 0.1 & 0.2 & 98.9 & 57.3 & 50.0 & 0.1 & 0.0 & 0.0 & 0.0 & 0.0 & 0.0 & 0.0 & 0.0 \\
\hline $\mathrm{Na}$ & 99.8 & 99.8 & 99.7 & 0.7 & 41.5 & 48.7 & 99.7 & 99.8 & 99.7 & 100.0 & 100.0 & 100.0 & 100.0 & 99.9 \\
\hline Ca+Hg & 0.2 & 0.1 & 0.1 & 0.4 & 1.2 & 1.3 & 0.2 & 0.2 & 0.3 & 0.0 & 0.0 & 0.0 & 0.0 & 0.1 \\
\hline
\end{tabular}

Oxides Recalculated to $100 \%$

\begin{tabular}{|c|c|c|c|c|c|c|c|c|c|c|c|c|c|c|}
\hline $\mathrm{SiO}_{2}$ & 66.03 & 66.42 & 64.20 & 67.90 & 66.09 & 65.41 & 66.10 & 65.69 & 66.53 & 63.91 & 64.59 & 64.82 & 64.64 & 65.76 \\
\hline $\mathrm{TiO}_{2}$ & 0.00 & 0.00 & 0.00 & 0.02 & 0.08 & 0.12 & 0.00 & 0.00 & 0.00 & ND & ND & 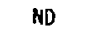 & ND & 0.06 \\
\hline $\mathrm{A}_{2} \mathrm{O}_{3}$ & 20.81 & 20.66 & 22.11 & 16.55 & 18.15 & 18.73 & 20.72 & 20.69 & 20.29 & 22.73 & 22.01 & 21.87 & 22.21 & 21.03 \\
\hline 00 & 0.00 & 0.00 & 0.00 & 0.01 & 0.11 & 0.12 & 0.08 & 0.06 & 0.03 & 0.06 & 0.04 & 0.01 & 0.04 & 0.00 \\
\hline gO & 0.00 & 0.00 & 0.00 & 0.02 & 0.00 & 0.01 & 0.02 & 0.02 & 0.04 & 0.00 & 0.00 & 0.00 & 0.00 & 0.02 \\
\hline Sau & 0.04 & 0.02 & & & $0.2 b$ & 0.26 & 0.02 & 0.02 & 0.02 & 0.00 & 0.00 & 0.00 & 0.00 & 0.00 \\
\hline 0 & $0.02^{\circ}$ & 0.00 & 0.00 & 0.05 & 0.85 & 0.99 & 0.00 & 0.10 & 0.00 & 0.03 & 0.06 & 0.20 & 0.00 & 0.00 \\
\hline$a_{2}$ & 13.09 & 12.88 & 13.62 & 0.07 & 4.66 & 5.60 & 13.05 & 13.42 & 13.09 & 13.28 & 13.30 & 13.10 & 13.11 & 13.13 \\
\hline & 0.00 & 0.01 & $u .04$ & 15.34 & 9.80 & 8.75 & 0.01 & 0.00 & 0.00 & 0.00 & 0.00 & 0.00 & 0.00 & U. 00 \\
\hline 2 & 00.00 & 190.00 & 100.00 & 100.00 & 100.00 & 100.00 & 100.00 & 200.00 & 100.00 & 200.00 & 100.00 & 100.00 & 00.00 & 00.00 \\
\hline
\end{tabular}

1 Depth from surface, in feet.

$2 \mathrm{Cpt}$ - clinoptilolite/heulandite; Anlc = analcime; AKF - authigenic alkali feldspar; Ahb = authigenic albite; VPKF = vapor phase sanidine; VPAD = vapor phase alDite; DKF = devitrification sanidine; Sm = smectite; Gi = glass. 
Microprobe Analyses of Secondary Minerals in the Lithic-Rich Tuff (cont)

\begin{tabular}{|c|c|c|c|c|c|c|c|c|c|c|c|}
\hline $\begin{array}{l}\text { Depthl } \\
\text { Mineral } \\
\text { Type }\end{array}$ & $\begin{array}{l}4876 \\
\text { Anle }\end{array}$ & $\begin{array}{l}4876 \\
\text { Anlc }\end{array}$ & $\begin{array}{l}4876 \\
\text { Anlc }\end{array}$ & $\begin{array}{l}4876 \\
\text { Anlc }\end{array}$ & $\begin{array}{l}4876 \\
\text { AKF }\end{array}$ & $\begin{array}{l}4876 \\
\text { AKF }\end{array}$ & $\begin{array}{l}4912 \\
\text { Anlc }\end{array}$ & $\begin{array}{l}4912 \\
\text { Anlc }\end{array}$ & $\begin{array}{l}4912 \\
\text { Anlc } \\
\end{array}$ & $\begin{array}{l}4912 \\
\text { AKF }\end{array}$ & $\begin{array}{l}4912 \\
\text { AKF } \\
\end{array}$ \\
\hline $\mathrm{SiU}_{2}$ & 59.10 & 56.70 & b9.90 & 57.30 & 65.40 & 67.20 & 57.10 & 58.40 & 57.00 & 67.00 & 66.30 \\
\hline $\mathrm{TiO}_{2}$ & 0.00 & 0.00 & 0.00 & 0.02 & 0.05 & 0.04 & NO & ND & ND & NO & ND \\
\hline $\mathrm{Al}_{2} \mathrm{O}_{3}$ & 18.80 & 20.40 & 18.80 & 19.00 & 16.90 & 16.40 & 19.90 & 20.00 & 20.80 & 16.60 & 17.10 \\
\hline $\mathrm{Feu}$ & 0.00 & 0.00 & 0.01 & 0.00 & 0.01 & 0.02 & 0.01 & 0.04 & 0.00 & 0.04 & 0.06 \\
\hline Mgu & 0.00 & 0.00 & 0.03 & 0.00 & 0.03 & 0.00 & 0.00 & 0.00 & 0.00 & 0.00 & 0.00 \\
\hline $\mathrm{CaU}$ & 0.00 & 0.00 & 0.02 & 0.00 & 0.00 & 0.01 & 0.00 & 0.00 & 0.00 & 0.00 & 0.01 \\
\hline BaU & 0.00 & 0.00 & 0.00 & 0.00 & 0.00 & 0.00 & 0.00 & 0.00 & 0.00 & 0.16 & 0.00 \\
\hline $\mathrm{Na}_{2} \mathrm{U}$ & 12.00 & 12. $\mathrm{BO}$ & 11.70 & 11.90 & 0.05 & 0.04 & 11.90 & 11.90 & 12.50 & 0.04 & 0.03 \\
\hline$k_{2} \bar{J}$ & 0.02 & 0.02 & 0.03 & 0.03 & 16.30 & 15.70 & 0.00 & 0.01 & 0.00 & 14.90 & 14.50 \\
\hline Total & 89.92 & 89.92 & 90.49 & 88.25 & 98.74 & 99.41 & 88.91 & 90.35 & 90.30 & 98.74 & 98.00 \\
\hline
\end{tabular}

Cation Formulas based on $7(0)$ for Analcime and $8(0)$ for Feldspars

$\begin{array}{llllllllllll}\mathrm{Si} & 2.537 & 2.452 & 2.549 & 2.510 & 3.055 & 3.098 & 2.484 & 2.497 & 2.449 & 3.098 & 3.081 \\ \mathrm{Ti} & 0.000 & 0.000 & 0.000 & 0.001 & 0.002 & 0.001 & \text { ND } & \text { ND } & \text { ND } & \text { ND } & \text { ND } \\ \mathrm{Al} & 0.951 & 1.040 & 0.943 & 0.981 & 0.931 & 0.891 & 1.020 & 1.008 & 1.054 & 0.905 & 0.937 \\ \mathrm{Fe} & 0.000 & 0.000 & 0.000 & 0.000 & 0.000 & 0.001 & 0.000 & 0.001 & 0.000 & 0.002 & 0.002 \\ \mathrm{Mg} & 0.000 & 0.000 & 0.002 & 0.000 & 0.002 & 0.000 & 0.000 & 0.000 & 0.000 & 0.000 & 0.000 \\ \mathrm{Ca} & 0.000 & 0.000 & 0.001 & 0.000 & 0.000 & 0.000 & 0.000 & 0.000 & 0.000 & 0.000 & 0.000 \\ \mathrm{Ba} & 0.000 & 0.000 & 0.000 & 0.000 & 0.000 & 0.000 & 0.000 & 0.000 & 0.000 & 0.003 & 0.000 \\ \mathrm{Ma} & 0.999 & 1.073 & 0.965 & 1.011 & 0.005 & 0.004 & 1.004 & 0.986 & 1.041 & 0.004 & 0.003 \\ \mathrm{~K} & 0.001 & 0.001 & 0.002 & 0.002 & 0.971 & 0.923 & 0.000 & 0.001 & 0.000 & 0.879 & 0.860\end{array}$

Coordination of Cations

\begin{tabular}{llllllllllll} 
Tet. & 3.488 & 3.491 & 3.493 & 3.492 & 3.986 & 3.989 & 3.504 & 3.505 & 3.503 & 4.003 & 4.017 \\
Oct. & 1.000 & 1.074 & 0.970 & 1.013 & 0.980 & 0.930 & 1.004 & 0.988 & 1.041 & 0.887 & 0.865 \\
Total & 4.488 & 4.566 & 4.463 & 4.505 & 4.966 & 4.919 & 4.508 & 4.493 & 4.545 & 4.891 & 4.882 \\
\multicolumn{2}{r}{} & & & & & & & & & & \\
Ratio of Si to Si+A) & & & & & & & & & \\
\multicolumn{2}{c}{0.727} & 0.702 & 0.730 & 0.719 & 0.766 & 0.777 & 0.709 & 0.712 & 0.699 & 0.774 & 0.767
\end{tabular}

Mol.2 Potassium, Sodium, and Calcium plus Magnesium

\begin{tabular}{|c|c|c|c|c|c|c|c|c|c|c|c|}
\hline$K$ & 0.1 & 0.1 & 0.2 & 0.2 & 99.3 & 99.6 & 0.0 & 0.1 & 0.0 & 99.6 & 99,6 \\
\hline $\mathrm{Na}$ & 99.9 & 99.9 & 99.5 & 99.8 & 0.5 & 0.4 & 100.0 & 99.9 & 100.0 & 0.4 & 0,3 \\
\hline $\mathrm{Ca}+\mathrm{Mg}$ & 0.0 & 0.0 & 0.3 & 0.0 & 0.2 & 0.1 & 0.0 & 0.0 & 0.0 & 0.0 & 0.1 \\
\hline
\end{tabular}

Oxides Recalculated to $100 \%$

\begin{tabular}{|c|c|c|c|c|c|c|c|c|c|c|c|}
\hline $\mathrm{SiO}_{2}$ & 65.73 & 63.06 & 66.20 & 64.93 & 66.23 & 67.60 & 64.22 & 64.64 & 63.12 & 67.85 & 67.65 \\
\hline $\mathrm{TiO}_{2}$ & 0.00 & 0.00 & 0.00 & 0.02 & 0.05 & 0.04 & ND & ND & ND & ND & ND \\
\hline $\mathrm{Al}_{2} \mathrm{U}_{3}$ & 20.91 & 22.69 & 20.78 & 21.53 & 17.12 & 16.50 & 22.38 & 22.14 & 23.03 & 16.81 & 17.45 \\
\hline $\mathrm{FeU}$ & 0.00 & 0.00 & 0.01 & 0.00 & 0.01 & 0.02 & 0.01 & 0.04 & 0.00 & 0.04 & 0.06 \\
\hline $\mathrm{MgO}$ & 0.00 & 0.00 & 0.03 & 0.00 & 0.03 & 0.00 & 0.00 & 0.00 & 0.00 & 0.00 & 0.00 \\
\hline $\mathrm{CaO}$ & 0.00 & 0.00 & 0.02 & 0.00 & 0.00 & 0.01 & 0.00 & 0.00 & 0.00 & 0.00 & 0.01 \\
\hline $\mathrm{BaC}$ & 0.00 & 0.00 & 0.00 & 0.00 & 0.00 & 0.00 & 0.00 & 0.00 & 0.00 & 0.16 & 0.00 \\
\hline $\mathrm{Ma}_{2} \mathrm{O}$ & 13.35 & 14.23 & 12.93 & 13.48 & 0.05 & 0.04 & 13.38 & 13.17 & 13.84 & 0.04 & 0.03 \\
\hline$k_{2} 0$ & 0.02 & 0.02 & 0.03 & 0.03 & 16.51 & 15.79 & 0.00 & 0.01 & 0.00 & 15.09 & 14.80 \\
\hline Total & 100.00 & 100.00 & 100.00 & 100.00 & 100.00 & 100.00 & 100.00 & 100.00 & 100.00 & 100.00 & 100.00 \\
\hline
\end{tabular}




\section{Microprobe Analyses of Secondary Minerails in the 01der Tuffs}

\begin{tabular}{|c|c|c|c|c|c|c|c|c|c|c|c|c|c|c|}
\hline $\begin{array}{l}\text { Xeptnd } \\
\text { lineral } \\
\text { Type }\end{array}$ & $\begin{array}{l}5026 \\
M D\end{array}$ & $\begin{array}{l}5026 \\
M A D\end{array}$ & $\begin{array}{l}5026 \\
\text { Mb }\end{array}$ & $\begin{array}{l}5026 \\
\text { AKF }\end{array}$ & $\begin{array}{l}5026 \\
\text { AKF }\end{array}$ & $\begin{array}{l}5026 \\
\text { AKF }\end{array}$ & $\begin{array}{l}5093 \\
\text { Anlc }\end{array}$ & $\begin{array}{l}5093 \\
\text { Anlc }\end{array}$ & $\begin{array}{l}5093 \\
\text { MAb }\end{array}$ & $\begin{array}{l}5093 \\
\text { A10 }\end{array}$ & $\begin{array}{l}5093 \\
\text { Mab }\end{array}$ & $\begin{array}{l}5093 \\
\text { MAD }\end{array}$ & $\begin{array}{l}5093 \\
\text { MAD }\end{array}$ & $\begin{array}{l}5093 \\
\text { MAD }\end{array}$ \\
\hline 0. & 68.60 & 67.70 & 68.10 & 66.60 & 66.20 & 66.20 & 59.20 & 59.40 & 69.10 & 69.50 & 69.40 & 70.10 & 70.00 & 69.10 \\
\hline $0_{2}$ & 0.02 & 0.03 & 0.00 & 0.04 & 0.01 & 0.03 & NO & NO & NO & no & ND & ND & ND & ND \\
\hline $1_{2} 0_{3}$ & 18.80 & 19.10 & 19.00 & 16.00 & 16.40 & 15.90 & 20.00 & 20.00 & 19.70 & 19.90 & 19.90 & 19.50 & 20.00 & 20.40 \\
\hline $\mathrm{et}$ & 0.08 & 0.00 & 0.00 & 0.00 & 0.02 & 0.00 & 0.00 & 0.00 & 0.08 & 0.07 & 0.02 & 0.01 & 0.02 & 0.02 \\
\hline gu & 0.00 & 0.00 & 0.00 & 0.00 & 0.00 & 0.00 & 0.00 & 0.00 & 0.00 & 0.00 & 0.00 & 0.00 & 0.00 & 0.00 \\
\hline 0 & 0.14 & 0.16 & 0.16 & 0.02 & 0.01 & 0.00 & 0.00 & 0.00 & 0.25 & 0.42 & 0.36 & 0.31 & 0.36 & 6.74 \\
\hline 0 & 0.00 & 0.00 & 0.00 & 0.07 & 0.00 & 0.05 & 0.00 & 0.00 & 0.00 & 0.00 & 0.00 & 0.00 & 0.00 & 0.08 \\
\hline$a_{2} 0$ & 11.70 & 11.90 & 11.20 & 0.07 & 0.07 & 0.04 & 11.70 & 11.80 & 11.40 & 11.40 & 11.70 & 11.50 & 11.40 & 11.30 \\
\hline$k_{2} 0$ & 0.04 & 0.07 & 0.09 & 15.70 & 15.10 & 15.20 & 0.00 & 0.00 & 0.07 & 0.03 & 0.04 & 0.05 & 0.07 & 0.03 \\
\hline$t a l$ & 9.38 & 18.96 & 8.55 & 98.50 & 97.81 & 97.42 & 90.90 & 91.20 & 00.60 & 01.32 & 01.42 & 01.47 & 01.85 & 101.67 \\
\hline
\end{tabular}

Cation Formulas Based on $7(0)$ for Analcime and $8(0)$ for Feldspars

$\begin{array}{lllllllllllllll}\text { Si } & 3.014 & 2.993 & 3.012 & 3.203 & 3.094 & 3.109 & 2.510 & 2.511 & 2.997 & 2.993 & 2.989 & 3.012 & 2.997 & 2.971 \\ \text { Ti } & 0.001 & 0.001 & 0.000 & 0.001 & 0.000 & 0.001 & \text { ND } & \text { ND } & \text { ND } & \text { ND } & \text { ND } & \text { ND } & \text { ND } & \text { ND } \\ \text { Al } & 0.974 & 0.995 & 0.991 & 0.879 & 0.904 & 0.881 & 1.000 & 0.997 & 1.007 & 1.010 & 1.010 & 0.988 & 1.009 & 1.034 \\ \mathrm{Fe} & 0.003 & 0.000 & 0.000 & 0.000 & 0.001 & 0.000 & 0.000 & 0.000 & 0.003 & 0.003 & 0.001 & 0.000 & 0.001 & 0.001 \\ \mathrm{Mg} & 0.000 & 0.000 & 0.000 & 0.000 & 0.000 & 0.000 & 0.000 & 0.000 & 0.000 & 0.000 & 0.000 & 0.000 & 0.000 & 0.000 \\ \mathrm{Ca} & 0.007 & 0.008 & 0.008 & 0.001 & 0.001 & 0.000 & 0.000 & 0.000 & 0.012 & 0.019 & 0.017 & 0.014 & 0.017 & 0.034 \\ \mathrm{Ba} & 0.000 & 0.000 & 0.000 & 0.001 & 0.000 & 0.001 & 0.000 & 0.000 & 0.000 & 0.000 & 0.000 & 0.000 & 0.000 & 0.001 \\ \text { Na } & 0.997 & 1.020 & 0.960 & 0.006 & 0.006 & 0.004 & 0.962 & 0.967 & 0.959 & 0.952 & 0.977 & 0.958 & 0.946 & 0.942 \\ \text { K } & 0.002 & 0.004 & 0.006 & 0.933 & 0.901 & 0.911 & 0.000 & 0.000 & 0.004 & 0.002 & 0.002 & 0.003 & 0.004 & 0.002\end{array}$

Coordination of Cations

$\begin{array}{lllllllllllllll}\text { Tet. } & 3.988 & 3.988 & 4.003 & 3.982 & 3.998 & 3.990 & 3.510 & 3.507 & 4.004 & 4.003 & 3.999 & 3.999 & 4.006 & 4.005 \\ \text { oct. } & 1.009 & 1.032 & 0.973 & 0.943 & 0.908 & 0.916 & 0.962 & 0.967 & 0.977 & 0.975 & 0.997 & 0.975 & 0.967 & 0.980 \\ \text { Total } & 4.998 & 5.021 & 4.976 & 4.926 & 4.907 & 4.907 & 4.471 & 4.475 & 4.981 & 4.979 & 4.996 & 4.975 & 4.974 & 4.984\end{array}$

Ratio of Si to Si+Al

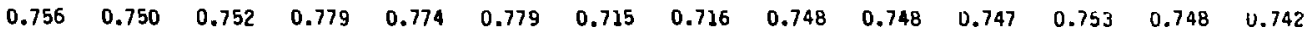

Mol.\% Potassium, Sodium, and Caicium plus Magnesium

\begin{tabular}{|c|c|c|c|c|c|c|c|c|c|c|c|c|c|c|}
\hline K & 0.2 & 0.4 & 0.5 & 99.2 & 99.2 & 99.6 & 0.0 & 0.0 & 0.4 & 0.2 & 0.2 & 0.3 & 0.4 & 0.2 \\
\hline Na & 99.1 & 98.9 & 98.7 & 0.7 & 0.7 & 0.4 & 100.0 & 100.0 & 98.4 & 97.8 & 98.1 & 98.3 & 97.9 & 96.3 \\
\hline$a++1 g$ & 0.7 & 0.7 & 0.8 & 0.1 & 0.1 & 0.0 & 0.0 & 0.0 & 1.2 & 2.0 & 1.7 & 1.5 & 1.7 & 3.5 \\
\hline
\end{tabular}

Uxides Recalculated to $100 \%$

\begin{tabular}{|c|c|c|c|c|c|c|c|c|c|c|c|c|c|c|}
\hline $\begin{array}{l}\mathrm{SiU}_{2} \\
\mathrm{TiO}_{2}\end{array}$ & $\begin{array}{l}69.03 \\
0.02\end{array}$ & $\begin{array}{r}58.41 \\
0.03\end{array}$ & $\begin{array}{r}69.10 \\
0.00\end{array}$ & $\begin{array}{r}67.61 \\
0.04\end{array}$ & $\begin{array}{r}67.68 \\
0.01\end{array}$ & $\begin{array}{r}67.95 \\
0.03\end{array}$ & $\begin{array}{l}65.13 \\
\text { ND }\end{array}$ & $\begin{array}{c}65.13 \\
\text { NO }\end{array}$ & $\begin{array}{c}68.69 \\
\text { ND }\end{array}$ & $\begin{array}{c}68.59 \\
\text { ND }\end{array}$ & $\begin{array}{c}68.43 \\
\text { ND }\end{array}$ & $\begin{array}{l}69.08 \\
\mathrm{HL}\end{array}$ & $\begin{array}{c}68.73 \\
\text { ND }\end{array}$ & $\begin{array}{c}67.96 \\
\text { ND }\end{array}$ \\
\hline${ }^{1} 1_{2} 0_{3}$ & 18.92 & 19.30 & 19.28 & 16.24 & 16.77 & 16.32 & 22.00 & 21.93 & 19.58 & 19.64 & 19.62 & 19.22 & 19.64 & 20.06 \\
\hline 20 & 0.08 & 0.00 & 0.00 & 0.00 & 0.02 & 0.00 & 0.00 & 0.00 & 0.08 & 0.07 & 0.02 & 0.01 & 0.02 & 0.02 \\
\hline 0 & 0.00 & In & 0 & 0.00 & 0.00 & 0.00 & 0.00 & 0. & 0. & 0.00 & 0.00 & 0.00 & 0.00 & 0.00 \\
\hline 0 & 0.14 & .16 & 0.16 & 0.02 & 0.01 & 0.00 & 0.00 & 0.00 & 0.25 & 0.41 & 0.35 & 0.31 & 0.35 & 0.73 \\
\hline 0 & 0.00 & 0.00 & 0.00 & 0.07 & 0.00 & 0.05 & 0.00 & 0.00 & 0.00 & 0.00 & 0.00 & 0.00 & 0.00 & 0.08 \\
\hline $\mathrm{Na}_{2} \mathrm{O}$ & 11.77 & .03 & 11.36 & 0.07 & 0.07 & 0.04 & 12.87 & 12.94 & 11.33 & 21.25 & 11.54 & 11.33 & 11.19 & 11.11 \\
\hline $\mathrm{K}_{2} \mathrm{O}$ & 0.04 & 0.07 & 0.09 & 15.94 & 15.44 & 15.60 & 0.00 & 0.00 & 0.07 & 0.03 & 0.04 & 0.05 & 0.07 & 0.03 \\
\hline ota & 100.00 & 00.00 & 00.00 & 100.00 & 00.00 & .00 .00 & 00.00 & 00.00 & 00.00 & 00.00 & 00.00 & 00.00 & 100.00 & 00.00 \\
\hline
\end{tabular}

\footnotetext{
1 Depth from surface, in feet.

$2 \mathrm{Cpt}=\mathrm{clinoptilolite/heulandite;} \mathrm{Anlc} \mathrm{=} \mathrm{analcime;} \mathrm{AKF} \mathrm{=} \mathrm{authigenic} \mathrm{alkall} \mathrm{feldspar;} \mathrm{Mab} \mathrm{=} \mathrm{authigentc} \mathrm{albite;}$ VPKF = vapor phase sanidine; YPAb = vapor phase albite; OKF = devitrification sanidine; Sm = smectite; Gl = glass.
} 
Microprobe Analyses of Secondary Minerals in the 01der Tuffs (cont)

\begin{tabular}{|c|c|c|c|c|c|c|c|c|c|c|c|c|c|c|}
\hline $\begin{array}{l}\text { Depth } \\
\text { Mineral } \\
\text { Type? }\end{array}$ & $\begin{array}{l}5093 \\
A A B\end{array}$ & $\begin{array}{l}5093 \\
A A b\end{array}$ & $\begin{array}{l}5126 \\
\text { Anlc }\end{array}$ & $\begin{array}{l}5126 \\
\text { Anlc }\end{array}$ & $\begin{array}{l}5126 \\
\text { AKF }\end{array}$ & $\begin{array}{l}5126 \\
A K F\end{array}$ & 5167 & $\begin{array}{l}5167 \\
\text { Anic }\end{array}$ & $\begin{array}{l}5167 \\
\text { Anle }\end{array}$ & $\begin{array}{l}5167 \\
\text { Anle }\end{array}$ & $\begin{array}{l}5167 \\
\text { Anlc }\end{array}$ & $\begin{array}{l}5167 \\
\text { Anlc }\end{array}$ & $\begin{array}{l}5167 \\
\text { Anle }\end{array}$ & $\begin{array}{l}5167 \\
A K F\end{array}$ \\
\hline $\mathrm{SiO}_{2}$ & 68.30 & 70.50 & 58.60 & 59.30 & 66.20 & 67.80 & 58.40 & 57.70 & 57.50 & 57.40 & 58.40 & 57.80 & 56.50 & 68.50 \\
\hline $\mathrm{TiO}_{2}$ & MO & ND & 0.00 & 0.00 & 0.04 & 0.02 & NO & ND & MD & MD & ND & No & ND & NO \\
\hline $\mathrm{Al}_{2} \mathrm{O}_{3}$ & 19.40 & 19.70 & 19.50 & 19.90 & 17.80 & 17.30 & 19.30 & 19.50 & 19.90 & 19.70 & 18.00 & 20.10 & 19.80 & 19.50 \\
\hline $\mathrm{Fe} 0$ & 0.09 & 0.00 & 0.01 & 0.03 & 0.03 & 0.13 & 0.00 & 0.00 & 0.01 & 0.00 & 0.01 & 0.00 & 0.00 & 0.00 \\
\hline $\mathrm{MgO}$ & 0.00 & 0.00 & 0.01 & 0.00 & 0.01 & 0.03 & 0.00 & 0.00 & 0.00 & 0.00 & 0.00 & 0.00 & 0.00 & 0.00 \\
\hline $\mathrm{CaO}$ & 0.21 & 0.25 & 0.03 & 0.00 & 0.03 & 0.01 & 0.00 & 0.02 & 0.00 & 0.01 & 0.00 & 0.04 & 0.00 & 0.40 \\
\hline$B a 0$ & 0.00 & 0.00 & .00 & 0.03 & 0.98 & 0.05 & 0.00 & 0.00 & 0.05 & 0.11 & 0.00 & 0.00 & 0.12 & 0.15 \\
\hline $\mathrm{Na}_{2} \mathrm{O}$ & 11.50 & 11.70 & 12.20 & 12.50 & 0.23 & 0.10 & 12.60 & 12.40 & 12.00 & 11.60 & 11.20 & 12.60 & 12.50 & 11.90 \\
\hline $\mathrm{K}_{2} \mathrm{O}$ & 0.05 & 0.04 & 0.01 & 0.02 & 16.50 & 16.20 & 0.00 & 0.00 & 0.00 & 0.00 & 0.00 & 0.00 & 0.00 & 0.03 \\
\hline Total & 99.55 & 102.19 & 90.36 & 91.78 & 101.82 & 101.64 & 90.30 & 89.62 & 89.46 & 88.82 & 87.61 & 90.54 & 88.92 & 100.48 \\
\hline
\end{tabular}

Cation Formulas Based on $7(0)$ for Analcime and $8(0)$ for Felospars

$\begin{array}{lcccccccccccccc}\text { Si } & 2.996 & 3.008 & 2.508 & 2.501 & 3.024 & 3.067 & 2.506 & 2.494 & 2.487 & 2.497 & 2.563 & 2.476 & 2.469 & 2.986 \\ \text { Ti } & \text { ND } & \text { ND } & 0.000 & 0.000 & 0.001 & 0.001 & \text { ND } & \text { NO } & \text { ND } & \text { ND } & \text { ND } & \text { ND } & \text { ND } & \text { ND } \\ \text { A1 } & 1.003 & 0.991 & 0.984 & 0.990 & 0.959 & 0.923 & 0.976 & 0.994 & 1.015 & 1.010 & 0.931 & 1.015 & 1.020 & 1.002 \\ \text { Fe } & 0.003 & 0.000 & 0.000 & 0.001 & 0.001 & 0.005 & 0.000 & 0.000 & 0.000 & 0.000 & 0.000 & 0.000 & 0.000 & 0.000 \\ \text { Mg } & 0.000 & 0.000 & 0.001 & 0.000 & 0.001 & 0.002 & 0.000 & 0.000 & 0.000 & 0.000 & 0.000 & 0.000 & 0.000 & 0.000 \\ \text { Ca } & 0.010 & 0.011 & 0.001 & 0.000 & 0.001 & 0.000 & 0.000 & 0.001 & 0.000 & 0.000 & 0.000 & 0.002 & 0.000 & 0.019 \\ \text { Ba } & 0.000 & 0.000 & 0.000 & 0.000 & 0.018 & 0.001 & 0.000 & 0.000 & 0.001 & 0.002 & 0.000 & 0.000 & 0.002 & 0.003 \\ \text { Na } & 0.978 & 0.968 & 1.012 & 1.022 & 1.118 & 0.009 & 1.048 & 1.039 & 1.006 & 0.978 & 0.953 & 1.047 & 1.059 & 1.006 \\ \text { K } & 0.003 & 0.002 & 0.001 & 0.001 & 0.962 & 0.935 & 0.000 & 0.000 & 0.000 & 0.000 & 0.000 & 0.000 & 0.000 & 0.002\end{array}$

Cooraination of Cations

\begin{tabular}{|c|c|c|c|c|c|c|c|c|c|c|c|c|c|c|}
\hline Tet. & 3.999 & 4.000 & 3.492 & 3.491 & 3.982 & 3.990 & 3.482 & 3.488 & 3.502 & 3.507 & 3.494 & 3.491 & 3.489 & 3.988 \\
\hline oct. & 0.994 & 0.982 & 1.015 & 1.025 & 1.004 & 0.953 & 1.048 & 1.040 & 1.008 & 0.981 & 0.953 & 1.048 & 1.061 & 1.029 \\
\hline Totdl & 4.993 & 4.981 & 4.507 & 4.516 & 4.987 & 4.943 & 4.530 & 4.528 & 4.509 & 4.487 & 4.448 & 4.540 & 4.550 & 5.017 \\
\hline
\end{tabular}

Ratio of 5 i to $S i+A l$
$0.749 \quad 0.752$
0.718
0.717
0.759
$0.769 \quad 0.720 \quad 0.715$
0.710
0.712
0.733
$0.709 \quad 0.708 \quad 0.749$

Mol. a Potassium, Sodium, and Calcium plus Magnesium

\begin{tabular}{|c|c|c|c|c|c|c|c|c|c|c|c|c|c|c|}
\hline k & 0.3 & 0.2 & 0.1 & 0.1 & 97.7 & 98.8 & 0.0 & 0.0 & 0.0 & 0.0 & 0.0 & 0.0 & 0.0 & 0.2 \\
\hline $\mathrm{Na}$ & 98.7 & 98.6 & 99.7 & 99.9 & 2.1 & 0.9 & 100.0 & 99.9 & 100.0 & 100.0 & 100.0 & 99.8 & 100.0 & 98.0 \\
\hline$a+M g$ & 1.0 & 1.2 & 0.2 & 0.0 & 0.2 & 0.3 & 0.0 & 0.1 & 0.0 & 0.0 & 0.0 & 0.2 & 0.0 & 1.8 \\
\hline
\end{tabular}

Oxides Recalculated to $100 \%$

\begin{tabular}{|c|c|c|c|c|c|c|c|c|c|c|c|c|c|c|}
\hline $\begin{array}{l}\mathrm{SiO}_{2} \\
\mathrm{TiO}_{2}\end{array}$ & $\begin{array}{l}68.61 \\
\text { ND }\end{array}$ & $\begin{array}{l}68.99 \\
\text { ND }\end{array}$ & $\begin{array}{r}54.85 \\
0.00\end{array}$ & $\begin{array}{r}64.61 \\
0.00\end{array}$ & $\begin{array}{r}65.02 \\
0.04\end{array}$ & $\begin{array}{r}66.71 \\
0.02\end{array}$ & $\begin{array}{l}64.67 \\
\text { ND }\end{array}$ & 64.38 & $\begin{array}{c}64.27 \\
\text { ND }\end{array}$ & 64.63 & 66.66 & $\begin{array}{l}63.84 \\
\text { NO }\end{array}$ & $\begin{array}{c}63.54 \\
\text { ND }\end{array}$ & $\begin{array}{l}68.17 \\
\text { ND }\end{array}$ \\
\hline${ }^{1}{ }_{2}{ }_{3}$ & & 19.28 & .5 & 1.68 & 17.48 & 17.02 & 21.37 & & & & & & & \\
\hline 0 & 0.09 & 0.00 & 0.01 & 0.03 & 0.03 & 0.13 & 0.00 & 0.00 & 0.01 & 0.00 & 0.01 & 0.00 & 0.00 & 0.00 \\
\hline & 0.00 & 0.00 & 0 & 0.00 & 0.01 & 0.03 & 0.00 & 0.00 & 0.00 & 0.00 & 0.00 & 0.00 & 0.00 & 0.00 \\
\hline & 0.21 & 0.24 & 0.03 & 0.00 & 0.03 & 0.01 & 0.00 & 0.02 & 0.00 & 0.01 & 0.00 & 0.04 & 0.00 & 0.40 \\
\hline & 0.00 & 0.00 & 0.00 & 0.03 & 0.96 & 0.05 & 0.00 & 0.00 & 0.06 & 0.12 & 0.00 & 0.00 & 0.13 & 0.15 \\
\hline$a_{2} 0$ & 11.55 & 11.45 & 13.50 & 13.62 & 0.23 & 0.10 & 13.95 & 13.84 & 13.41 & 13.06 & 12.78 & 13.92 & 14.06 & 11.84 \\
\hline $\mathrm{K}_{2} \mathrm{O}$ & 0.05 & 0.04 & 0.01 & 0.02 & 16.21 & 15.94 & 0.00 & 0.00 & 0.00 & 0.00 & 0.00 & 0.00 & 0.00 & 0.03 \\
\hline$x$ & 90.00 & 00.00 & 00.00 & 00.00 & 00.00 & 00.00 & 100.00 & 00.00 & 00.00 & 00.00 & 100.00 & 100.00 & 100.00 & 100.00 \\
\hline
\end{tabular}

1 Depth from surface, in feet.

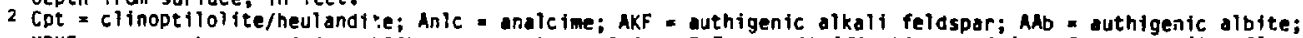
VPKF * vapor phase sanidine; VPAD = vapor phase albite; DKF - devitrification sanidine; Sn = smectite; GI - glass. 
Microprobe Analyses of Secondary Minerals in the 0lder Tuffs (cont)

\begin{tabular}{|c|c|c|c|c|c|c|c|c|c|c|c|c|c|c|}
\hline $\begin{array}{l}\text { Depthl } \\
\text { Minera1 } \\
\text { Type? }\end{array}$ & $\begin{array}{l}5212 \\
\text { Anlc }\end{array}$ & $\begin{array}{l}5212 \\
\text { Anlc }\end{array}$ & $\begin{array}{l}5212 \\
\text { Anlc }\end{array}$ & $\begin{array}{l}5212 \\
\text { Anlc }\end{array}$ & $\begin{array}{l}5212 \\
\text { AKF }\end{array}$ & $\begin{array}{l}5212 \\
\text { AKF }\end{array}$ & $\begin{array}{l}5296 \\
\text { Anic }\end{array}$ & $\begin{array}{l}5296 \\
\text { Anlc }\end{array}$ & $\begin{array}{l}5296 \\
\text { Anlc }\end{array}$ & $\begin{array}{l}5296 \\
\text { Anlc }\end{array}$ & $\begin{array}{l}5296 \\
\text { Anlc }\end{array}$ & $\begin{array}{r}5296 \\
\text { AKF }\end{array}$ & $\begin{array}{r}5296 \\
\text { AKF }\end{array}$ & $\begin{array}{r}5296 \\
\text { AKF }\end{array}$ \\
\hline $\mathrm{SiO}_{2}$ & 59.40 & 60.00 & 58.70 & 59.80 & 68.70 & 67.10 & 56.50 & 59.10 & 59.00 & 59.90 & 59.20 & 65.90 & 67.90 & 66.30 \\
\hline $\mathrm{TiO}_{2}$ & 0.00 & 0.00 & 0.00 & 0.00 & 0.03 & 0.05 & HD & ND & ND & ND & ND & ND & ND & NO \\
\hline $\mathrm{Al}_{2} \mathrm{O}_{3}$ & 18.50 & 18.80 & 19.40 & 18.90 & 16.60 & 17.10 & 19.50 & 20.00 & 19.80 & 20.30 & 19.50 & 17.20 & 16.80 & 17. \\
\hline $\mathrm{FeO}^{2}$ & 0.00 & 0.14 & 0.10 & 0.04 & 0.03 & 0.43 & 0.02 & 0.04 & 0.04 & 0.05 & 0.05 & 0.07 & 0.00 & \\
\hline$M 90$ & 0.01 & 0.01 & 0.02 & 0.00 & 0.02 & 0.05 & 0.00 & 0.00 & 0.00 & 0.00 & 0.00 & 0.00 & 0.00 & \\
\hline $\mathrm{CaO}$ & 0.02 & 0.03 & 0.02 & 0.02 & 0.02 & 0.04 & 0.00 & 0.00 & 0.00 & 0.00 & 0.00 & $0.0^{n}$ & 0.00 & \\
\hline $8 \mathrm{a} 0$ & 0.13 & 0.05 & 0.05 & 0.05 & 0.03 & 0.05 & 0.12 & 0.09 & 0.00 & 0.01 & 0.70 & 0.15 & 0.00 & \\
\hline $\mathrm{Na}_{2} \mathrm{O}$ & 11.30 & 11.80 & 11.70 & 11.70 & 0.07 & 0.19 & 11.80 & 11.90 & 12.00 & 11.70 & 11.70 & 0.03 & 0.10 & 3 \\
\hline $\mathrm{K}_{2} \mathrm{O}$ & 0.03 & 0.28 & 0.00 & 0.02 & 15.90 & 16.30 & 0.00 & 0.00 & 0.00 & 0.00 & 0.01 & 14.90 & 13.80 & 14. \\
\hline Total & 89.39 & 91.11 & B9.99 & 90.53 & 101.40 & 101.31 & 87.94 & 91.13 & 90.84 & 91.96 & 91.16 & 98.25 & 98.60 & \\
\hline
\end{tabular}

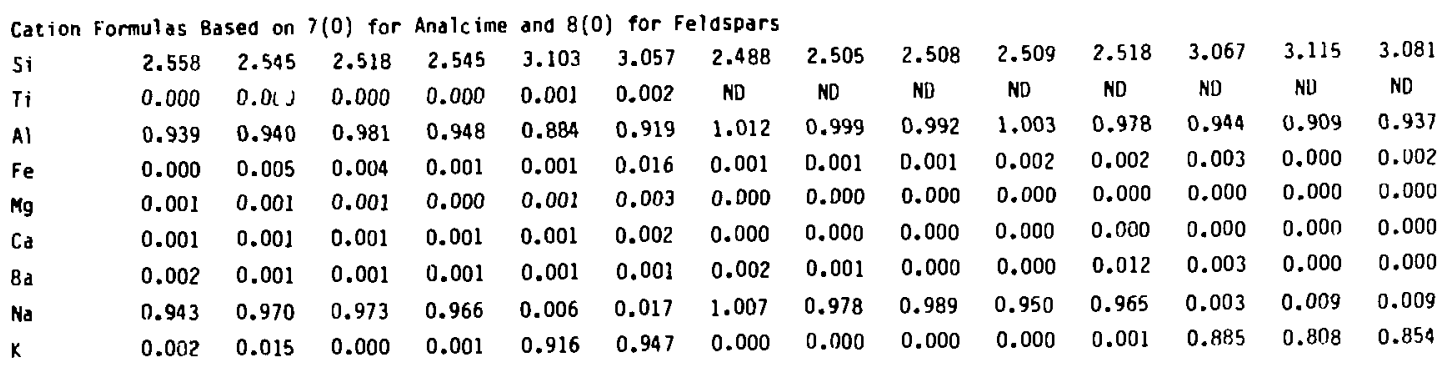

Cocrdination of Cations

\begin{tabular}{|c|c|c|c|c|c|c|c|c|c|c|c|c|c|c|}
\hline Tet. & 3.497 & 3.485 & 3.499 & 3.494 & 3.987 & 3.976 & 3.500 & 3.504 & 3.500 & 3.512 & 3.496 & 4.011 & 4.023 & 4.018 \\
\hline & 0.949 & 0.993 & 0.980 & 0.970 & 0.927 & 0.989 & 1.010 & 0.981 & 0.990 & 0.952 & 0.979 & 0.893 & 0.816 & 0.865 \\
\hline al & 4.445 & 4.478 & 4.478 & 4.464 & 4.915 & 4.964 & 4.510 & 4.485 & 4.491 & 4.464 & 4.475 & 4.904 & 4.840 & 4.882 \\
\hline
\end{tabular}

Ratio of si to Si+Al

$$
\begin{array}{llllllllllllll}
0.331 & 0.730 & 0.720 & 0.729 & 0.378 & 0.769 & 0.711 & 0.715 & 0.717 & 0.715 & 0.720 & 0.765 & 0.774 & 0.767
\end{array}
$$

Mol.x Potassium, Sadium, and Calctum plus Magnesium

\begin{tabular}{|c|c|c|c|c|c|c|c|c|c|c|c|c|c|c|}
\hline$k$ & 0.2 & 1.5 & 0.0 & 0.1 & 99.1 & 97.7 & 0.0 & 0.0 & 0.0 & 0.0 & 0.1 & 99.7 & 98.9 & 99.0 \\
\hline $\mathrm{Na}$ & 99.7 & 98.3 & 99.8 & 99.8 & 0.7 & 1.7 & 100.0 & 100,0 & 100.0 & 100.0 & 99.9 & 0.3 & 1.1 & 1 \\
\hline $\mathrm{Ca}+\mathrm{Mg}$ & 0.2 & 0.2 & 0.2 & 0.1 & 0.3 & 0.6 & 0.0 & 0.0 & 0.0 & 0.0 & 0.0 & 0.0 & 0.0 & 0 \\
\hline
\end{tabular}

Oxides Recalculated to $100 \%$

\begin{tabular}{|c|c|c|c|c|c|c|c|c|c|c|c|c|c|c|}
\hline $\mathrm{SiO}_{2}$ & 66.45 & 65.85 & 65.23 & 66.06 & .67 .75 & 66.23 & 64.25 & 64.85 & 64.95 & 65.14 & 64.94 & 67.07 & 68.86 & 67.69 \\
\hline $\mathrm{TiO}_{2}$ & 0.00 & 0.00 & 0.00 & 0.00 & 0.03 & 0.05 & NO & No & ND & NO & ND & ND & ND & ND \\
\hline $\mathrm{Al}_{2} \mathrm{O}_{3}$ & 20.70 & 20.63 & 21.56 & $20.8 B$ & 16.37 & $16.8 \mathrm{~B}$ & 22.17 & 21.95 & 21.80 & 22.07 & 21.39 & 17.51 & 17.04 & 17.46 \\
\hline $\mathrm{FeO}$ & 0.00 & 0.15 & 0.11 & 0.04 & 0.03 & 0.42 & 0.02 & 0.04 & 0.04 & 0.05 & 0.05 & 0.07 & 0.00 & 0.05 \\
\hline $\mathrm{MgO}$ & 0.01 & 0.01 & 0.02 & 0.00 & 0.02 & 0.05 & 0.00 & 0.00 & 0.00 & 0.00 & 0.00 & 0.00 & 0.00 & 0.00 \\
\hline $\mathrm{CaO}$ & 0.02 & 0.03 & 0.02 & 0.02 & 0.02 & 0.04 & 0.00 & 0.00 & 0.00 & 0.00 & 0.00 & 0.00 & 0.00 & 0.00 \\
\hline $\mathrm{BaO}$ & 0.15 & 0.05 & 0.06 & 0.06 & 0.03 & 0.05 & 0.14 & 0.10 & 0.00 & 0.01 & 0.77 & 0.15 & 0.00 & 0.00 \\
\hline $\mathrm{Na}_{2} \mathrm{O}$ & 12.64 & 12.95 & 13.00 & 12.92 & 0.07 & 0.19 & 13.42 & 13.06 & 13.21 & 12.72 & 12.83 & 0.03 & 0.10 & 0.10 \\
\hline$K_{2} 0$ & 0.03 & 0.31 & 0.00 & 0.02 & 15.68 & 16.09 & 0.00 & 0.00 & 0.00 & 0.00 & 0.01 & 15.17 & 14.00 & 14.70 \\
\hline Total & 100.00 & 100.00 & 100.00 & 100.00 & 100.00 & 100.00 & 100.00 & 100.00 & 100.00 & 100.00 & 100.00 & 100.00 & 100.00 & 100.00 \\
\hline
\end{tabular}

1 Depth fram surface, in feet.

$2 \mathrm{Cpt}$. Clinoptilolite/heulandite; Anlc = analcime; AKF = authigenic alkali feldspar; AAb = authigenic albite; VPKF = vapior phase sanidine; VPAD = vapor phase albite; DKF = devitrification sanioine; Sm = smectite; Gl = glass. 
Microprobe Analyses of Secondary Minerals in the Older Tuffs (cont)

\begin{tabular}{|c|c|c|c|c|c|c|c|c|c|c|c|c|c|c|c|}
\hline $\begin{array}{l}\text { Depthd } \\
\text { Mineral } \\
\text { Type }{ }^{2}\end{array}$ & $\begin{array}{r}\$ 296 \\
\text { AKF }\end{array}$ & $\begin{array}{r}5296 \\
\text { AKF }\end{array}$ & $\begin{array}{r}5296 \\
\text { AKF }\end{array}$ & $\begin{array}{r}5296 \\
M \mathrm{Mb}\end{array}$ & $\begin{array}{l}\text { 5311 } \\
\text { Anic }\end{array}$ & $\begin{array}{l}5311 \\
\text { Anic }\end{array}$ & $\begin{array}{l}53 \mathrm{~J} \\
\mu_{b}\end{array}$ & $\begin{array}{l}5311 \\
M \mathrm{Mb}\end{array}$ & $\begin{array}{l}531 \mathrm{~J} \\
\mathrm{Mb}\end{array}$ & $\begin{array}{l}5311 \\
\text { VPKF }\end{array}$ & $\begin{array}{r}5348 \\
\text { AKF }\end{array}$ & $\begin{array}{l}5348 \\
\text { AKF }\end{array}$ & $\begin{array}{l}5412 \\
\text { Anle }\end{array}$ & $\begin{array}{l}\text { b412 } \\
\text { Anic }\end{array}$ & $\begin{array}{l}\text { b412 } \\
\text { Anle }\end{array}$ \\
\hline 年 & 68.50 & 67.10 & 67.90 & 68.40 & 58.90 & 59.60 & 69.50 & 69.80 & 68.60 & 66.00 & 67.90 & 69.40 & $b 6.40$ & 57.30 & 58.00 \\
\hline $\mathrm{IiO}_{2}$ & ND & no & NO & MD & 0.00 & 0.00 & 0.03 & 0.01 & 0.01 & 0.17 & 0.02 & 0.00 & 0.02 & 0.01 & 0.00 \\
\hline $\mathrm{Al}_{2} \mathrm{O}_{3}$ & 17.30 & 16.70 & 16.90 & 19.70 & 19.80 & 19.50 & 19.10 & 19.20 & 19.60 & 18.70 & 15.90 & 16.20 & 19.90 & 19.00 & 19.30 \\
\hline $\mathrm{FeO}$ & 0.04 & 0.04 & 0.07 & 0.04 & 0.03 & 0.00 & 0.04 & 0.00 & 0.07 & 0.21 & 0.07 & 0.02 & 0.00 & 0.00 & 0.01 \\
\hline mgu & 0.00 & 0.00 & .00 & 0.00 & 0.00 & 0.00 & 0.00 & 0.02 & 0.01 & 0.02 & 0.00 & 0.00 & 0.00 & 0.00 & U.uU \\
\hline $\mathrm{CaO}$ & 0.00 & 0.00 & .00 & 0.28 & 0.02 & $.0 b$ & 0.34 & 0.26 & 0.55 & 0.22 & 0.00 & 0.00 & 0.00 & 0.02 & 0.00 \\
\hline 880 & 0.06 & 0.15 & 0.15 & 0.00 & 0.17 & 0.00 & 0.13 & 0.15 & 0.00 & 1.83 & 0.02 & 0.09 & 0.00 & 0.00 & 0.00 \\
\hline $\mathrm{Ma}_{2} \mathrm{O}$ & 0.05 & 0.05 & 0.03 & 11.60 & 12.20 & 12.20 & 11.50 & 11.70 & 11.50 & 3.57 & 0.16 & 0.10 & 12.40 & 12.10 & 12.00 \\
\hline $\mathrm{k}_{2}{ }^{0}$ & 15.00 & 14.50 & 14.70 & 0.04 & 0.01 & 0.01 & 0.09 & 0.10 & 0.06 & 11.20 & 15.30 & 14.40 & 0.00 & 0.01 & 0.00 \\
\hline ot a 1 & 100.95 & 98.54 & 99.75 & 100.06 & 1.13 & 11.36 & 100.73 & 101.24 & 100.40 & 101.92 & 99.37 & 100.21 & 88.72 & 88.44 & 89.31 \\
\hline
\end{tabular}

Cation formulas Based on $7(0)$ for Aralcime and $8(0)$ for Feldspars

\begin{tabular}{|c|c|c|c|c|c|c|c|c|c|c|c|c|c|c|c|}
\hline Si & 3.091 & 3.101 & 3,100 & 2.986 & 2.502 & 2.520 & 3.014 & 3.013 & 2.987 & 2.982 & 3.123 & 3.141 & 2.467 & 2.507 & 2.510 \\
\hline $\mathrm{Ii}$ & NO & NO & NO & HO & 0.000 & 0.000 & 0.001 & 0.000 & 0.000 & 0.006 & 0.001 & 0.000 & 0.001 & 0.000 & 0.000 \\
\hline Al & 0.920 & 0.910 & 0.910 & 1.014 & 0.992 & 0.972 & 0.977 & 0.977 & 1.006 & 0.996 & 0.862 & 0.864 & 1.026 & 0.980 & 0.985 \\
\hline $\mathrm{Fe}$ & 0.002 & 0.002 & 0.003 & 0.001 & 0.001 & 0.000 & 0.001 & 0.000 & 0.003 & 0.008 & 0.003 & 0.001 & 0.000 & 0.000 & 0.000 \\
\hline$M g$ & 0.000 & 0.000 & 0.000 & 0.000 & 0.000 & 0.000 & 0.000 & 0.001 & 0.001 & 0.001 & 0.000 & 0.000 & 0.000 & 0.000 & 0.000 \\
\hline Ca & 0.000 & 0.000 & 0.000 & 0.013 & 0.001 & 0.002 & 0.016 & 0.012 & 0.026 & 0.011 & 0.000 & 0.000 & 0.000 & 0.001 & 0.000 \\
\hline $8 a$ & 0.001 & 0.003 & 0.003 & 0.000 & 0.003 & 0.000 & 0.002 & 0.003 & 0.000 & 0.032 & 0.000 & 0.002 & 0.000 & 0.000 & 0.000 \\
\hline $\mathrm{Ma}$ & 0.004 & 0.004 & 0.003 & 0.982 & 1.005 & 1.000 & 0.967 & 0.979 & 0.971 & 0.313 & 0.014 & 0.009 & 1.052 & 1.027 & 1.007 \\
\hline $\mathbf{k}$ & 0.864 & 0.855 & 0.856 & 0.002 & 0.001 & 0.001 & 0.005 & 0.006 & 0.003 & 0.646 & 0.898 & 0.831 & 0.000 & 0.001 & 0.000 \\
\hline
\end{tabular}

Coordination of Cations

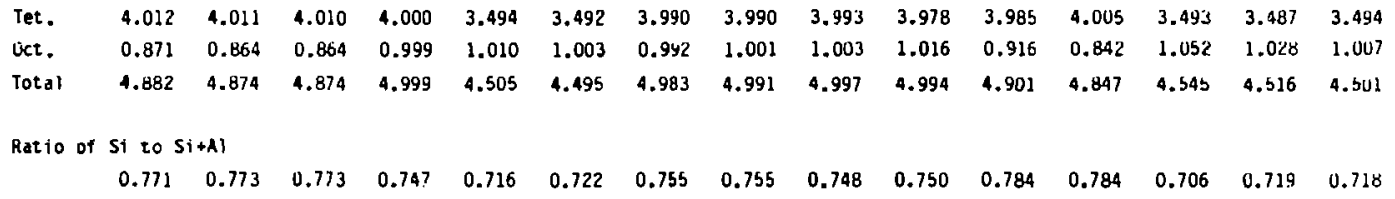

Mol.1 Potassium, Sodium, and Cajcium plus Magnesium

\begin{tabular}{|c|c|c|c|c|c|c|c|c|c|c|c|c|c|c|c|}
\hline$k$ & 99.5 & 99.5 & 99.7 & 0.2 & 0.1 & 0.1 & 0.5 & 0.6 & 0.3 & 66.5 & 98.4 & 99.0 & 0.0 & 0.1 & 0.0 \\
\hline $\mathbf{N}$ & 0.5 & 0.5 & 0.3 & 98.5 & 99.9 & 99.7 & 97.9 & 98.1 & 97.0 & 32.2 & 3.6 & 1.0 & 100.0 & 99.9 & 100.0 \\
\hline gathos & 0.0 & 0.0 & 0.0 & 1.3 & 0.1 & 0.2 & 1.6 & 1.3 & 2.6 & 1.2 & 0.0 & 0.0 & 0.0 & 0.1 & 0.0 \\
\hline
\end{tabular}

Oxides Recalculated to $100 \%$

\begin{tabular}{|c|c|c|c|c|c|c|c|c|c|c|c|c|c|c|c|}
\hline $\begin{array}{l}\mathrm{SiO}_{2} \\
\mathrm{IiO}_{2}\end{array}$ & $\begin{array}{l}67.86 \\
\text { No }\end{array}$ & $\begin{array}{l}68.09 \\
\text { No }\end{array}$ & $\begin{array}{l}68.07 \\
\text { м0 }\end{array}$ & $\begin{array}{l}68.36 \\
\text { MO }\end{array}$ & $\begin{array}{r}64.63 \\
0.00\end{array}$ & $\begin{array}{r}65.24 \\
0.00\end{array}$ & $\begin{array}{r}69.00 \\
0.03\end{array}$ & $\begin{array}{r}68.95 \\
0.01\end{array}$ & $\begin{array}{r}68.33 \\
0.01\end{array}$ & $\begin{array}{r}64.76 \\
0.17\end{array}$ & $\begin{array}{r}68.33 \\
0.02\end{array}$ & $\begin{array}{r}69.25 \\
0.00\end{array}$ & $\begin{array}{r}63.57 \\
0.02\end{array}$ & $\begin{array}{r}64.79 \\
0.01\end{array}$ & $\begin{array}{r}64.94 \\
0.00\end{array}$ \\
\hline $\mathrm{Al}_{2} \mathrm{U}_{3}$ & 17.14 & 16.95 & 16.94 & 19.69 & 21.73 & 21.34 & 18.96 & 18.96 & 19.52 & 18.35 & 16.00 & 16.17 & 22.43 & 21.48 & 21.61 \\
\hline $\mathrm{Fe} 0$ & 0.04 & 0.04 & 0.07 & 0.04 & 0.03 & 0.00 & 0.04 & 0.00 & 0.07 & 0.21 & 0.07 & 0.02 & 0.00 & 0.00 & 0.01 \\
\hline Mgu & 0.00 & 0.00 & 0.00 & 0.00 & 0.00 & 0.00 & 0.00 & 0.02 & 0.01 & 0.02 & 0.00 & 0.00 & 0.00 & 0.00 & 0.00 \\
\hline $\mathrm{CaO}$ & 0.00 & 0.00 & 0.00 & 0.28 & 0.02 & 0.05 & 0.34 & 0.26 & 0.55 & 0.22 & 0.00 & 0.00 & 0.00 & 0.02 & 0.00 \\
\hline Bau & 0.06 & 0.15 & 0.15 & 0.00 & 0.19 & 0.00 & 0.13 & 0.15 & 0.00 & 1.80 & 0.02 & 0.09 & 0.00 & 0.00 & 0.00 \\
\hline $\mathrm{Ne}_{2} \mathrm{O}$ & 0.05 & 0.05 & 0.03 & 11.59 & 13.39 & 13.35 & 11.42 & 11.56 & 11.45 & 3.50 & 0.16 & 0.10 & 13.98 & 13.68 & 13.44 \\
\hline$k_{2} 0$ & 14.86 & 14.71 & 14.74 & 0.04 & 0.01 & 0.01 & 0.09 & 0.10 & 0.06 & 10.99 & 15.40 & 14.37 & 0.00 & 0.01 & 0.00 \\
\hline Total & 100.00 & 100.00 & 100.00 & 100.00 & 100.00 & 100.00 & 100.00 & 100.00 & 100.00 & 100.00 & 100.00 & 100.00 & 100.00 & 100.00 & 100.00 \\
\hline
\end{tabular}


Microprobe Analyses of Secondary Minerals in the 01der Tuffs (cont)

\begin{tabular}{|c|c|c|c|c|c|c|c|c|c|c|c|c|c|c|}
\hline $\begin{array}{l}\text { Depth1 } \\
\text { Mineral } \\
\text { Type? }\end{array}$ & $\begin{array}{l}5412 \\
\text { AKF }\end{array}$ & $\begin{array}{l}5412 \\
\text { AKF }\end{array}$ & $\begin{array}{l}5412 \\
A A b\end{array}$ & $\begin{array}{l}5412 \\
A R B\end{array}$ & $\begin{array}{l}5498 \\
\text { Anic }\end{array}$ & $\begin{array}{l}549 B \\
\text { Anlc }\end{array}$ & $\begin{array}{l}5498 \\
\text { Anic }\end{array}$ & $\begin{array}{l}5498 \\
\text { Anle }\end{array}$ & $\begin{array}{l}544 B \\
\text { AKF }\end{array}$ & $\begin{array}{l}5498 \\
\text { AKF }\end{array}$ & $\begin{array}{l}5444 \\
\text { AAb }\end{array}$ & $\begin{array}{l}54^{\prime}+8 \% \\
M a b\end{array}$ & $\begin{array}{l}5 x_{31} \\
\text { AABS }\end{array}$ & $\begin{array}{l}\text { 'bis's } \\
\text { Anle. }\end{array}$ \\
\hline $\mathrm{SIO}_{2}$ & 66.40 & 67.40 & 68.30 & 66.60 & 57.50 & 58.40 & 57.50 & 58.10 & 67.20 & 66.90 & 69.70 & 64.20 & 68.411 & $5 \%$ \\
\hline $\mathrm{THO}_{2}$ & 0.07 & 0.02 & 0.00 & 0.05 & MD & ND & ND & NO & ND & NU & M() & ND & Ku & 0.0.0 \\
\hline $\mathrm{Al}_{2} \mathrm{D}_{3}$ & 16.80 & 16.50 & 19.40 & 19.10 & 20.00 & 20.00 & 19.90 & 19.90 & 17.00 & 17.00 & 18.90 & 14.30 & 19.90 & 19.601 \\
\hline $\mathrm{FeO}$ & 0.04 & 0.01 & 0.01 & 0.00 & 0.00 & 0.00 & 0.00 & 0.00 & 0.00 & 0.00 & 0.00 & 0.00 & 0.01 & $0.01)$ \\
\hline $\operatorname{lng} 0$ & 0.00 & 0.02 & 0.00 & 0.00 & ND & HD & ND & NO & No & ND & NU & ND & 0.010 & 0.00 \\
\hline $\mathrm{CaO}$ & 0.02 & 0.02 & 0.02 & 0.06 & 0.00 & D. 02 & 0.05 & 0.00 & 0.03 & 0.00 & 0.02 & 0.174 & 0.42 & 0.114 \\
\hline Ba 0 & 0.00 & 0.10 & 0.00 & 0.00 & 0.00 & 0.00 & 0.02 & 0.00 & 0.00 & 0.00 & 0.00 & 0.156 & 0.03 & 0.11 \\
\hline $\mathrm{Na}_{2} \mathrm{O}$ & 0.32 & 0.05 & 11.90 & 11.60 & 12.00 & 11.70 & 11.60 & 11.80 & 0.03 & 0.06 & 11.70 & 11.40 & 11.50 & 12.210 \\
\hline$K_{2}{ }^{0}$ & 15.00 & 15.50 & 0.09 & 0.12 & 0.00 & 0.01 & 0.00 & 0.06 & 15.30 & 15.30 & 0.09 & 0.09 & 0.04 & $0.0 \%$ \\
\hline Total & 98.65 & 99.62 & 99.72 & 97.53 & 89.50 & 90.13 & 89.07 & 89.86 & 99.56 & 99.26 & 100.41 & 100.59 & 1001.30 & 1.24 \\
\hline
\end{tabular}

Cation formulas based on $7(0)$ for Analcime and $B(0)$ for Felaspars

\begin{tabular}{|c|c|c|c|c|c|c|c|c|c|c|c|c|c|c|}
\hline si & 3.079 & 3.098 & 2.993 & 2.986 & 2.485 & 2.500 & 2.492 & 2.497 & 3.085 & 3.082 & 3.026 & 3.005 & $2.945_{1}^{\prime}$ & 2.513 \\
\hline Ti & 0.002 & 0.001 & 0.000 & 0.002 & ND & ND & MD & ND & NO & NU & ND & NI & Nij & $\left.0 .(0)^{r}\right)^{(r)}$ \\
\hline Al & 0.918 & 0.894 & 1.002 & 1.010 & 1.019 & 1.009 & 1.017 & 1.008 & 0.920 & 0.923 & 0.968 & $0.94 \%$ & 1.022 & 0.474 \\
\hline $\mathrm{Fe}$ & 0.002 & 0.000 & 0.000 & 0.000 & 0.000 & 0.000 & 0.000 & 0.000 & 0.000 & 0.000 & 0.000 & 0.000 & 0.000 & 0.00010 \\
\hline $\mathrm{Mg}$ & 0.000 & 0.001 & 0.000 & 0.000 & ND & NO & NO & NO & ND & NO & ND & NIJ & 0.000 & 0.0005 \\
\hline Ca & 0.001 & 0.001 & 0.001 & 0.003 & 0.000 & 0.001 & 0.002 & 0.000 & 0.001 & 0.000 & 0.001 & 0.002 & 0.020 & 0.0502 \\
\hline Ba & 0.000 & 0.002 & 0.000 & 0.000 & 0.000 & 0.000 & 0.000 & 0.000 & 0.000 & 0.000 & 0.000 & 0.001 & 0.001 & 0.006 \\
\hline $\mathrm{Na}$ & 0.029 & 0.004 & 1.011 & 1.008 & 1.005 & 0.971 & 0.975 & 0.983 & 0.003 & 0.005 & 0.985 & 1.002 & 0.971 & 1.002 \\
\hline k. & 0.887 & 0.909 & 0.005 & 0.007 & 0.000 & 0.001 & 0.000 & 0.003 & 0.896 & 0.899 & 0.005 & 0.005 & 0.002 & $0 .\left(U^{\prime}\right) \mathrm{s}$ \\
\hline
\end{tabular}

Coordination of Cations

\begin{tabular}{|c|c|c|c|c|c|c|c|c|c|c|c|c|c|c|}
\hline Tet. & 3.997 & 3.992 & 3.996 & 3.995 & 3.503 & 3.509 & 3.509 & 3.505 & 4.005 & 4.005 & 3.994 & 3.994 & 4.002 & 3.492 \\
\hline oct. & 0.921 & 0.919 & 1.018 & 1.020 & 1.005 & 0.972 & 0.978 & 0.987 & 0.900 & 0.904 & 0.991 & 1.010 & 0.994 & 1.0017 \\
\hline Total & 4.918 & 4.911 & 5.014 & 5.015 & 4.509 & 4.481 & 4.487 & 4.492 & 4.905 & 4.909 & 4.985 & 5.004 & 4.996 & 499 \\
\hline
\end{tabular}

Ratio of Si to $S i+A\}$
0.770
0.776
0.749
$0.747 \quad 0.709$
$0.712 \quad 0.710 \quad 0.712$
0.770
$0.769 \quad 0.758 \quad 0.753$
$0.745 \quad 0.720$

Mol.x Patassium, Sodium, and Calctum plus Magnestum

\begin{tabular}{|c|c|c|c|c|c|c|c|c|c|c|c|c|c|c|}
\hline K & 96.8 & 99.3 & 0.5 & 0.7 & 0.0 & 0.1 & 0.0 & 0.3 & 99.5 & 99.4 & 0.5 & 0.5 & 0.2 & 0.1 \\
\hline $\mathrm{Na}$ & 3.1 & 0.5 & 99.4 & 99.0 & 100.0 & 99.8 & 99.8 & 99.7 & 0.3 & 0.6 & 99.4 & 99.3 & 97.8 & 99.7 \\
\hline $\mathrm{Ca}+\mathrm{Mg}$ & 0.1 & 0.3 & 0.1 & 0.3 & 0.0 & 0.1 & 0.2 & 0.0 & 0.2 & 0.0 & 0.1 & 0.2 & 2.0 & 0.2 \\
\hline
\end{tabular}

Oxides Recalculated to $100 x$

\begin{tabular}{|c|c|c|c|c|c|c|c|c|c|c|c|c|c|c|}
\hline $\mathrm{SiO}_{2}$ & 1 & .66 & .49 & .29 & 64.25 & .80 & 1.5 & 64.66 & 67.50 & 57.40 & 69.42 & 68.79 & 68.20 & 4.96 \\
\hline $\mathrm{TiO}_{2}$ & 07 & .02 & 00 & 5 & n. & ND & ND & ND & No & ND & NO & NO & KD & 0.00 \\
\hline $0_{3}$ & 17.03 & .56 & 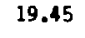 & 1.5 & 22. & 2.19 & 2.34 & 22.15 & 17.08 & 17.13 & 18.82 & 19.19 & 19.84 & 21.47 \\
\hline 0 & 04 & .01 & .01 & 0.00 & 0.00 & .00 & 0.00 & 0.00 & 0.00 & 0.00 & 0.00 & 0.00 & 0.01 & 0.00 \\
\hline 0 & 00 & .02 & .00 & 0.00 & & & & & & NI & NO & ND & 0.00 & 0.00 \\
\hline 0 & 0.02 & .02 & 0.02 & 0.06 & 0.00 & 0.02 & 0.06 & 0.00 & 0.03 & 0.00 & 0.02 & 4 & .42 & 0.04 \\
\hline$a$ & 00 & 0.10 & .00 & 0.00 & 00 & .00 & 0.02 & 0.00 & 0.00 & 0.00 & 0.00 & 6 & .03 & .14 \\
\hline 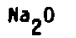 & 32 & 0.05 & 11.93 & 11.89 & 13.41 & 12.98 & 13.02 & 13.13 & 0.03 & 0.06 & 11.65 & 11.83 & 11.47 & 13.36 \\
\hline 0 & 15.21 & 15.56 & 0.09 & 0.12 & 0.00 & 0.01 & 0.00 & 0.07 & 15.37 & 15.41 & 0.09 & 0.09 & 0.04 & 0.02 \\
\hline & 100.00 & 100.00 & 00.00 & 00.00 & 100.00 & 100.00 & 00.00 & 00.00 & .00 .00 & 100.00 & 100.00 & 00.00 & 100.00 & .00 .00 \\
\hline
\end{tabular}

Depth from surface, in feet.

2 Cpt = Clinoptilolite/heulandite; Anlc = analcime; AKF = authigenic olkali felaspar; AAb = authigenic albite;

VPKF = vapor phase sanidine; VPAD = vapor phase albite; DKF = devitrification sanidine; Sm = smectite; Gl = glass. 
